\title{
1-Aminobenzotriazole: A Mechanism-Based Cytochrome P450 Inhibitor and Probe of Cytochrome P450 Biology
}

Paul R Ortiz de Montellano*

Department of Pharmaceutical Chemistry, University of California, San Francisco, CA 94143, USA

\begin{abstract}
1-Aminobenzotriazole (1-ABT) is a pan-specific, mechanism-based inactivator of the xenobiotic metabolizing forms of cytochrome P450 in animals, plants, insects, and microorganisms. It has been widely used to investigate the biological roles of cytochrome P450 enzymes, their participation in the metabolism of both endobiotics and xenobiotics, and their contributions to the metabolism-dependent toxicity of drugs and chemicals. This review is a comprehensive evaluation of the chemistry, discovery, and use of 1-aminobenzotriazole in these contexts from its introduction in 1981 to the present.
\end{abstract}

Keywords: Cytochrome P450; Mechanism-based inhibition; Heme adducts; 1-Aminobenzotriazole; Benzyne; Arachidonic acid oxidation; Estradiol; Xenobiotics; Drug metabolism

\section{Introduction}

The inhibition of cytochrome P450 enzymes to study their roles in the metabolism of endogenous compounds and xenobiotics, and for potential practical purposes, began as soon as this class of enzymes was recognized in the early 1960s [1]. Initially, the most commonly used inhibitors were SKF-525A, which inhibits multiple isoforms [2], and metyrapone, which inhibits what became known as the CYP2B class of P450 enzymes, but was primarily utilized as an inhibitor of P450 enzymes in the steroid biosynthetic pathway [3]. With increasing understanding of the native complement of cytochrome P450 enzymes in humans and other species, particularly the understanding provided by genomic data, the search for cytochrome $\mathrm{P} 450$ inhibitors diverged into two tracks.

One direction for this search was the identification of inhibitors that are isoform specific, or as close to that as possible, as these can be used to probe the biology and/or exploit the inhibition of individual cytochrome P450 enzymes. These inhibitors could be competitive, non-competitive, quasi-irreversible, or mechanism-based [4,5]. On the other hand, agents have also been sought that are pan-specific, i.e., that broadly inhibit the complement of cytochrome P450 enzymes involved in drug metabolism, while minimally perturbing the P450 enzymes involved in biosynthetic processes. These agents include SKF-525A and ketoconazole [6,7], but this review focuses on 1-aminobenzotriazole (1-ABT), a widely employed mechanism-based inhibitor. Comparisons of 1-ABT and SKF-525A in investigations of drug metabolism by cytochrome P450 enzymes delineate the advantages of 1-ABT. For example, SKF-525A disrupts autophagy in primary rat hepatocytes, whereas 1-ABT and several other P450 inhibitors do not [8]. In another study, SKF-525A and ketoconazole were shown to inhibit CCKinduced $\left[\left(\mathrm{Ca}^{2+}\right)\right]$-induced oscillations in rat pancreatic acinar cells, whereas 1-ABT did not [9].

The currently available reviews on cytochrome P450 inhibition take a horizontal perspective that surveys the breadth of the field (e.g., $[5,10,11])$. This review pursues a vertical, comprehensive analysis of the relevant chemistry, biochemistry, and biology associated with 1-aminobenzotriazole.

\section{Chemistry of 1-Aminobenzotriazole (1-ABT)}

1-Aminobenzotriazole, abbreviated as 1-ABT, was first prepared in 1960 [12], but a more practical synthesis was subsequently described by Campbell and Rees [13]. These authors also demonstrated that oxidation of 1 -ABT by lead tetra-acetate resulted in the release of nitrogen gas and the essentially quantitative formation of benzyne, as established by its dimerization and trapping by other substrates. For example, it reacts with tetraphenylcyclopentadienone to give 1,2,3,4-tetraphenylnapthalene after loss of CO from the initial adduct (Figure 1) [14]. As Campbell and Rees also showed that the oxidation of 1-ABT by other chemical agents gave similar results [15].

\section{Discovery of 1-ABT as a Cytochrome P450 Inactivating Agent}

In view of the chemistry of $1-\mathrm{ABT}$, its biological oxidation by cytochrome P450 enzymes was examined to determine if this would produce benzyne within a biological environment. In effect, incubation of rat liver microsomes with $1-\mathrm{ABT}$ in the presence of the cofactor NADPH led to rapid loss of the cytochrome P450 chromophore and the accumulation of a novel porphyrin [16]. Cytochrome P450 inactivation requires NADPH and is inhibited by $\mathrm{CO}$, features which implicate an autocatalytic process. Glutathione does not prevent cytochrome P450 loss, which suggests that this is a mechanism-based process in which benzyne generated within the enzyme active site reacts with the heme before diffusing away from the active site cavity [16]. Exposure of isolated perfused rabbit lungs or microsomes from such lungs showed that 1-ABT caused loss of both specific P450 content and the ethoxyresorufin $\mathrm{O}$-deethylation and benzphetamine $\mathrm{N}$-demethylase activities [17]. These losses were detectable at concentrations of 1-ABT above $10 \mu \mathrm{M}$, with maximum losses occurring at concentrations above $1 \mathrm{mM}$. At the higher concentrations of 1-ABT, the losses of $\mathrm{P} 450$ and benzphetamine $\mathrm{N}$-demethylase activity were similar. Furthermore, covalent binding of radiolabeled 1 -ABT to lung microsomes $(0.3 \mathrm{nmol} / \mathrm{mg}$ protein $)$ was similar to the spectroscopically measured loss of cytochrome P450 (0.3 $\mathrm{nmol} / \mathrm{mg}$ protein) [17], suggesting a stoichiometric process. 1-ABT

*Corresponding author: Paul R Ortiz de Montellano, Department of Pharmaceutical Chemistry, University of California, San Francisco, CA 94143 USA, Tel: 4154762903; E-mail: ortiz@cgl.ucsf.edu

Received March 22, 2018; Accepted March 27, 2018; Published March 31, 2018

Citation: Ortiz de Montellano PR (2018) 1-Aminobenzotriazole: A MechanismBased Cytochrome P450 Inhibitor and Probe of Cytochrome P450 Biology. Med Chem (Los Angeles) 8: 038-065. doi: 10.4172/2161-0444.1000495

Copyright: () 2018 Ortiz de Montellano PR. This is an open-access article distributed under the terms of the Creative Commons Attribution License, which permits unrestricted use, distribution, and reproduction in any medium, provided the original author and source are credited. 
also inhibited the metabolism of resorufin ethers in the livers and skin of mice [18] and of ethoxycoumarin by rat liver slices, isolated hepatocytes, and hepatic microsomes [19].

Based on its UV-visible spectrum, resistance to forming a zinc complex, and mass spectrometric molecular ion, the accumulated porphyrin was tentatively identified as protoporphyrin IX with a benzene group forming a bridge between two nitrogen atoms of the porphyrin (Figure 2) [20]. NMR analysis of the modified porphyrin isolated from rats treated in vivo with 1-ABT unambiguously confirmed this structure. In addition, a second minor fluorescent product was isolated that was identified as $\mathrm{N}$-phenylprotoporphyrin IX, in which a phenyl group is attached to only one of the nitrogens of the porphyrin. It was estimated that less than 12 molecules of 1 -ABT were consumed per molecule of $\mathrm{P} 450$ inactivated.

The oxidation of 1-ABT by $\mathrm{P} 450$ enzymes could be envisaged to proceed via either (path a) initial N-hydroxylation followed by dehydration and then fragmentation, or (path b) sequential hydrogen abstractions from the exocyclic nitrogen followed by fragmentation (Figure 3). Relevant experimental data is scarce, but DFT computational studies favor the two hydrogen abstraction model (path b) of Figure 3 [21]. However, as will be discussed in a later section on derivatives of 1-ABT, N-monoalkyl 1-aminobenzotriazoles also inactivate cytochrome P450 [22]. It is possible that these agents act by a different mechanism than 1-ABT itself, but if not, it would suggest that, at least in some instances, sequential removal of two hydrogens is not required for benzyne generation.

\section{Metabolism and Pharmacokinetics of 1-ABT}

The major metabolite observed in the plasma of male rats after oral administration of ${ }^{14} \mathrm{C}$-labeled 1 -ABT was the $\mathrm{N}$-acetyl derivative, but the $\mathrm{N}$-glucuronides of $1-\mathrm{ABT}$ and of benzotriazole were also found in the urine (Figure 4) [23]. N-acetylation of 1-ABT by human $\mathrm{N}$-acetyltransferases NAT1 and NAT2 has been confirmed by in vitro incubations in studies, which also demonstrated that 1-ABT is a time-independent inhibitor of the $\mathrm{N}$-acetyltransferases in rat liver [24]. In contrast, 1-ABT was not found to be a measurable inhibitor of rat liver glucuronosyl transferases or sulfotransferases, as judged by its failure to inhibit the action of these enzymes on acetaminophen and 7-hydroxycoumarin, respectively. The absence of glucuronosyl transferase inhibition in rats was independently reported [25].

Although the benzotriazole glucuronide (Figure 4) was detected in the urine of rats, benzotriazole was not observed in the serum or urine [23]. However, benzotriazole itself was reported as the primary detectable metabolite in incubations of ${ }^{14} \mathrm{C}$-labeled 1-ABT with guinea pig hepatic or pulmonary microsomes [26]. The authors postulated a plausible mechanism in which hydroxylation of the exocyclic nitrogen is followed by elimination of $\mathrm{HNO}$ to give benzotriazole (Figure 5).

Oral administration of ${ }^{14} \mathrm{C}$-labeled $1-\mathrm{ABT}$ to male rats showed that the compound is absorbed slowly, $50 \%$ of the radioactivity remaining in the stomach $6 \mathrm{~h}$ after dosing, with maximum plasma and tissue concentrations observed at $24 \mathrm{~h}$ [23]. Of the initial dose, $71 \%$ was excreted in the urine and $12 \%$ in the feces over a period of $72 \mathrm{~h}$. Measurement of radioactivity in the various tissues showed that the highest tissue-to-plasma ratios were in the liver, adrenals, and kidneys, with half-lives of elimination from these tissues of $\sim 24,16$, and $24 \mathrm{~h}$, respectively. The plasma half-life was $\sim 9 \mathrm{~h}$.

Comparison of the effect of oral and intravenous 1-ABT on the bioavailability of midazolam in rats revealed that bioavailability was

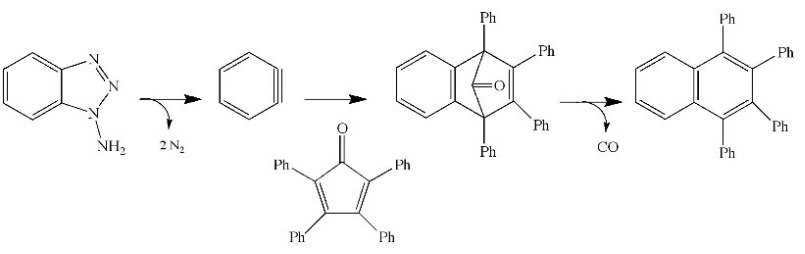

Figure 1: Oxidation of 1-ABT (compound 1) produces benzyne, which can be chemically trapped to give 1,2,3,4-tetraphenylnaphthalene.

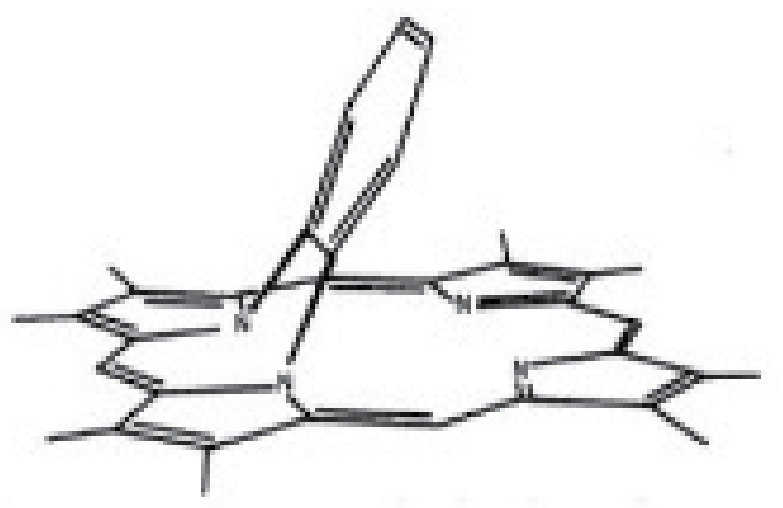

Figure 2: Heme adduct formed by reaction of the heme of cytochrome P450 with autocatalytically activated 1-ABT. The peripheral substituents on the porphyrin are only shown schematically, as isomeric structures that differ in the pattern of peripheral substitution are possible.<smiles>Nn1nnc2ccccc21</smiles><smiles>CC(C)CC(C)C</smiles><smiles>CC(C)OC1CCCCC1</smiles><smiles>Nn1nnc2ccccc21</smiles><smiles>Nn1nnc2ccccc21</smiles>

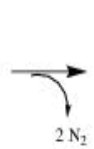<smiles>c1ccccc1</smiles>
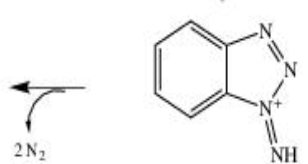

Figure 3: Two possible mechanisms for the P450-catalyzed oxidation of 1-ABT to benzyne, where $\left[\mathrm{Por}^{+} \mathrm{Fe}(\mathrm{IV})=\mathrm{O}\right]$ stands for the activated iron oxo species of cytochrome P450.<smiles>CC(=O)Nn1nnc2ccccc21</smiles><smiles>O=C(O)C1OC(Nn2nnc3ccccc32)C(O)C2(O)COC1C2O</smiles><smiles>O=C(O)C1OC2(n3nnc4ccccc43)CC(O)C1C2O</smiles>

Figure 4: Metabolites of 1-ABT formed in vivo in rats. 


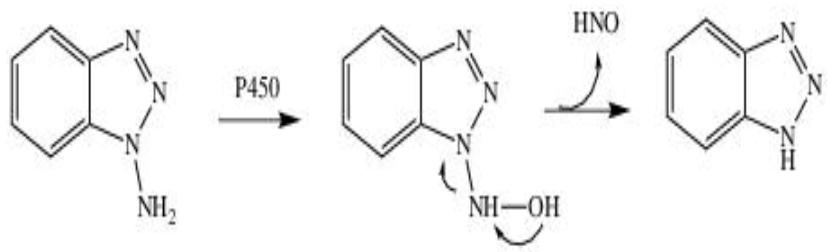

Figure 5: Possible mechanism for the P450-catalyzed conversion of 1-ABT to benzotriazole.

much lower with oral administration, which led to the conclusion that 1-ABT inactivated intestinal P450 enzymes, which are responsible for most of midazolam metabolism [27]. This led to the proposal that $1-\mathrm{ABT}$ can be used to evaluate gut versus liver clearance of drugs. Using metoprolol as a probe, the AUC was found to increase 16- and 6.5-times when 1-ABT was co-administered orally and intravenously, respectively [28]. This difference was interpreted as being due to a delay in the absorption of 1-ABT. However, a different study concluded from the fact that concentration-time curves were linear and proportional to the dose that $1-\mathrm{ABT}$ is rapidly absorbed into the systemic circulation in rats and has a $\mathrm{t}_{1 / 2}$ of $8-13 \mathrm{~h}[29]$. It has also been reported that $1-\mathrm{ABT}$ delays gastric emptying in rats and can alter systemic exposure and $\mathrm{T}_{\max }$ of coadministered agents [30]. The observation that $50 \mathrm{mg} / \mathrm{kg}$ of $1-\mathrm{ABT}$ inhibited antipyrine clearance by $88 \%$ when given shortly before the antipyrine, but only by $29 \%$ when given $24 \mathrm{~h}$ before, suggested that the duration of 1-ABT was relatively short [31]. However, The pharmacokinetic profiles of oral doses of 1-ABT ranging from 5 to 200 $\mathrm{mg} / \mathrm{kg}$, determined in rats, dogs, and monkeys, showed that a single dose of $50 \mathrm{mg} / \mathrm{kg}$ in rats and $20 \mathrm{mg} / \mathrm{kg}$ in dogs and monkeys produced high plasma concentrations that were sustained over 24 hours [32]. This resulted in inhibition of the plasma clearance of antipyrine by $88 \%$ in rats, $96 \%$ in dogs, and $83 \%$ in monkeys. Using a serial sampling method after administration of 50,100 , and $150 \mathrm{mg} / \mathrm{kg}$ oral doses to mice and guinea pigs revealed that the plasma 1-ABT concentrations were maintained at levels of $5-100 \mu \mathrm{M}$ for at least 12 hours in both species [33]. In vitro studies indicated that the $\mathrm{K}_{\mathrm{i}}$ values for $1-\mathrm{ABT}$ as a mechanism-based inactivator were 45.6 and $193 \mu \mathrm{M}$ in mice and guinea pigs, respectively, with the corresponding $\mathrm{k}_{\text {inact }}$ values of 0.089 and $0.075 \mathrm{~min}^{-1}$. Administration of 1-ABT 2 hours before intravenous antipyrine decreased plasma antipyrine clearance by approximately $95 \%$ in mice and $84-95 \%$ in guinea pigs at all the doses of 1 -ABT examined [33]. Osmotic pumps can be used to maintain maximum blood concentrations of 1 -ABT for at least 6 days [31]. Indeed, ALZET osmotic pumps were able to maintain the 1-ABT plasma concentration above $4.1 \mathrm{mg} / \mathrm{ml}$ over 336 hours without overt toxicity [34]. A convenient LC/MS/MS assay for the quantitation of 1-ABT in pharmacokinetic studies has been reported [35]. On the other hand, a test of the residual effects of 1-ABT and quinidine on drug disposition in rats after a 7-day washout period suggested that this period suffices to return to the original pharmacokinetics observed with naive rats [36].

\section{Specificity of 1-ABT}

\section{Cytochrome P450}

Early work showed that the cytochrome P450 enzymes induced in rat liver by phenobarbital and 3-methylcholanthrene were similarly inactivated by 1 -ABT [37]. Furthermore, similar amounts of N,N'-aryl bridged porphyrin adducts were obtained from male and female rat livers after treatment with 1-ABT [38]. Other early studies supported the conclusion that $1-\mathrm{ABT}$ was a relatively non-selective inactivating agent for cytochrome P450 enzymes. It inactivated the liver, lung, and kidney P450 enzymes of uninduced, phenobarbital pretreated, and $\beta$-naphthoflavone-pretreated guinea pigs [39], the rat liver and lung enzymes before and after pretreatment with $\beta$-naphthoflavone [40], and recombinant human P450 enzymes in microsomes from baculovirus infected insect cells [7]. The use of isoform selective probe substrates indicated that pooled human liver microsomes incubated with $1 \mathrm{mM} 1$-ABT for $30 \mathrm{~min}$ resulted in complete inactivation of CYP2A6 and CYP3A4, but retention of a residual activity of up to $20 \%$ with CYP1A2, $-2 \mathrm{~B} 6,-2 \mathrm{C} 8,-2 \mathrm{C} 9,-2 \mathrm{C} 19$, and -2D6 [41]. In this study, CYP2C 9 was particularly resistant, with $60 \%$ of the activity remaining. A separate study indicated that $1-\mathrm{ABT}$ caused a concentration dependent inhibition of CYP1A2, -2B6, -2C9, -2C19, -2D6, and -3A4 [32]. A later study showed, however, that addition of (S)-warfarin together with 1 -ABT resulted in potent inactivation of CPY2C9, presumably because $1-\mathrm{ABT}$ is displaced from the (S)-warfarin binding site to one more favorable for its oxidation [42]. In accord with catalysis-dependent inactivation, inhibition of baculovirus-expressed P450 enzymes is less differentiated from those of ketoconazole and SKF-525A in the absence of preincubation under turnover conditions [6].

The inactivation of CYP2E1 by 1-ABT has been extensively investigated. An early study demonstrated that 1-ABT caused loss of CPY2E1 activity but not loss of the protein, whereas $\mathrm{CCl}_{4}$ caused loss of both the activity and the protein [43]. The modification of CYP2E1 by $1-\mathrm{ABT}$ thus does not trigger rapid degradation of the $\mathrm{P} 450$ protein, in contrast to modification by $\mathrm{CCl}_{4}$. The inactivation of CYP2E1 by 1 -ABT has been used to establish the role of this enzyme in the metabolism of acrylamide [44], methacrylonitrile [45], 1,3-butadiene [46], urethane [47], and chlorzoxazone [48].

CYP4A11, a human fatty acid $\omega$-hydroxylase, is inactivated by 1-ABT, but interestingly, its L131F mutant is not [49]. In the case of CYP4A1, the homologous rat enzyme, the wild-type enzyme and its E320A mutant are not inactivated by 1-ABT, but the D323E and E320A/D323E mutants are inactivated [50]. Suppression of inactivation of CYP4A11 by the L131F mutation, and enabling of inactivation of CYPA1 by a D323A mutation, are ascribed to alterations in steric interference to the productive binding of 1-ABT. These results are reminiscent of the finding that occupying the $(S)$-warfarin site of CYP2C9 enables its much more effective inactivation by 1-ABT [42].

The cytochrome P450 enzymes involved in sterol biosynthetic pathways appear to be resistant to the action of 1-ABT. In incubations with guinea pig adrenal microsomes it did not inhibit the 11-, 17aor 21-sterol hydroxylases [51,52]. However, 1-ABT did inhibit the activities of these enzymes when administered in vivo to rats or guinea pigs [53-55]. It was postulated that an extra-adrenal metabolite of 1-ABT was responsible for the in vivo inactivation of the adrenal enzymes despite their resistance to inactivation in vitro. Inactivation of CYP51 has been cited [56], but no evidence for this is available in the published literature.

It is important to note that cytochrome $\mathrm{P} 450$ reductase, the electron donor partner of most cytochrome P450 enzymes, is not inactivated in rats by incubation with 1-ABT in the presence of NADPH [57]. Similarly, 1-ABT does not inhibit cytochrome $b_{5}$, which is an alternative electron donor for some P450 enzymes [25]. Comparable results were obtained in studies of P450 inactivation in a plant enzyme system [58]. The loss of P450 activities is thus due to inactivation of the hemoproteins themselves rather than their electron donor partners.

Species differences in susceptibility to inactivation of $\mathrm{P} 450$ metabolism have been reported. The oxidation of ketamine by human 
and canine liver microsomes was markedly inhibited, but little inhibition was seen with equine microsomes [59].

1-ABT has been used to inactivate cytochrome P450 enzymes in non-mammalian species, including plants, insects, fungi, and bacteria. This aspect of 1-ABT specificity is addressed in the section that describes inactivation in these species.

\section{Proteins other than cytochrome $\mathbf{P 4 5 0}$}

The interactions of proteins other than the cytochrome P450 enzymes with 1-ABT has been examined to provide a context for any physiological observations that may be made when this agent is used to inactivate $\mathrm{P} 450$ enzymes in intact cells, tissues, or animals. Inhibition of oxidative enzymes other than the cytochromes P450, for example, would complicate specific attribution of a physiological consequence to inactivation of cytochrome P450 enzymes. The flavin monooxygenase (FMO) family of enzymes is of concern in this regard, as their oxidative activities towards heteroatomic substrates resemble those of the P450 enzymes. However, a number of studies have established that 1-ABT is neither a substrate nor an inhibitor of the FMO enzymes. Thus, $1-\mathrm{ABT}$ has no effect on lung or liver FMO enzymes [17,22,60,61]. One consequence of this is that 1-ABT has been used to determine the relative roles of FMO and P450 enzymes in the oxidative metabolism of xenobiotics (Table 1).

1-ABT is reported to not be an inhibitor of horseradish peroxidase, as it does not inhibit the oxidation of o-anisidine by this enzyme [68], but measurements of the binding of benzo[a]pyrene to serum bovine albumin in the presence of horseradish peroxidase and $\mathrm{H}_{2} \mathrm{O}_{2}$ suggested that this process is inhibited by 1-ABT [69]. Based on indirect evidence, the inference has been made that 1-ABT interacts with hemoglobin [70]. However, clear and convincing evidence that 1-ABT actually inhibits horseradish peroxidase or interacts with hemoglobin is not available. In contrast, chloroperoxidase, a cytochrome P450-like enzyme with a thiolate iron ligand clearly oxidizes $1-\mathrm{ABT}$ to phenol and is inactivated in the process [20].

1-ABT is a substrate for $\mathrm{N}$-acetyltransferases and inhibits these enzymes [71]. 1-ABT is also reportedly a non-competitive inhibitor of mouse, rat, and human monoamine oxidases with $\mathrm{K}_{\mathrm{i}}$ values of 7.87 . 8.61 , and $65.2 \mu \mathrm{M}$, respectively, when measured in vitro with S9 liver fractions [56]. It does not, however, inhibit aldehyde oxidase [72], $\alpha, \beta$-ketone reductase [73], or $3 \beta$-hydroxysteroid dehydrogenase [53]. Although the glucuronide of 1-ABT has been observed in rat urine [23], 1-ABT has no inhibitory activity against the rat glucuronosyl transferases and sulfotransferases [24] and little if any against the human glucuronosyl transferases [74]. Indeed, in rat hepatocytes, treatment with $1-\mathrm{ABT}$ increased the formation of the 1-O-acyl glucuronides of gemfibrozil, tolmetin, mefenamic acid, and diclofenac, and the $S$-acyl glutathione conjugates of mefenamic acid and diclofenac [75]. 1-ABT also does not significantly alter the glutathione transferase activities or glutathione levels in rat liver or kidney [25].

Studies with sandwich-cultured human hepatocytes indicate that
1-ABT does not alter the hepatic transport of rosuvastatin, atorvastatin, or midazolam [71]. Work published in a poster supported the inference that $1-\mathrm{ABT}$ does not interfere with transporters, as concentrations of 1-ABT up to $1 \mathrm{mM}$ did not inhibit the MDR1, Bcrp1, and MRP2 transporters [76]. In another study, the in vivo clearance of GNE1, an inhibitor of the p21-activated kinase PAK1, was lower than predicted [77]. The use of transporter knockout rats with and without 1-ABT administration indicated that the clearance of this agent is determined by uptake transporters rather by metabolism. These results indicate that 1-ABT does not interfere with transporters. However, 1-ABT can interact with transporter inhibitors by inhibiting the metabolism of drugs whose concentration is elevated due to transporter inhibition. As a case in point, the toxicity of nefazodone, which inhibits bile acid transport, is due to the unmetabolized drug. The toxicity of this drug is potentiated by 1-ABT, which prevents metabolism of nefazodone [78]. Similarly, inhibition of the bile acid export pump, which results in accumulation of bile acids in hepatocytes, can be potentiated by inhibition of the metabolism of pump inhibitors by 1-ABT [79].

\section{Induction of Cytochrome P450 Enzymes}

In an early study, administration of 1-ABT to rats was not found to induce the mRNA or P450 protein levels for what were then known as cytochromes $\mathrm{P} 450 \mathrm{~b}$ and $\mathrm{P} 450 \mathrm{e}$, nor did 1-ABT prevent the elevation of P450 mRNA levels caused by co-administration of phenobarbital or 3-methylcholanthrene [80]. However, two decades later 1-ABT was found to upregulate the expression of CYP2B6 and CYP3A4 mRNA in a concentration dependent manner in freshly isolated human hepatocytes. Indirect data suggested that $1-\mathrm{ABT}$ is a CAR, but not PXR activator [81]. In another study with primary cultured rat hepatocytes, $1-\mathrm{ABT}$ was found to indirectly increase CYP2B mRNA levels, possibly by inhibiting the initial step in the conversion of monocarboxylic to dicarboxylic fatty acids, thereby decreasing peroxisomal $\beta$-oxidation and increasing intracellular fatty acid levels [82].

\section{Toxicity of 1-ABT}

1-ABT has been reported to have no readily observable toxicity when administered to houseflies [83], wheat seedlings [84], beagle dogs [85], rats [85,86], or mice [86]. Furthermore, administration of 1-ABT to mice via an ALZET osmotic pump for 16 days caused no overt toxicity [34]. The results of a more detailed 13-week toxicological and pathologic evaluation of the effects of 1-ABT generally agree with this conclusion [87]. This study showed that in male Sprague-Dawley rats hepatic P450 levels and resorufin dealkylation activity were reduced to less than $30 \%$ of control values without obvious signs of toxicity such as changes in body weight, food consumption, or clinical appearance. Hemoglobin, hematocrit, and erythrocyte counts decreased slightly, whereas mean corpuscular hemoglobin concentration, mean corpuscular volume, red cell distribution width, and mean corpuscular hemoglobin were slightly increased. Some accumulation of lipids was suggested by an increase in liver weight, centrilobular hypertrophy, and intracytoplasmic vacuolization. Thyroid stimulating hormone was slightly elevated and triiodothyronine and thyroxin were slightly

Table 1: Some compounds for which the role of P450 versus FMO has been investigated using 1-ABT as a P450 inactivating agent.

\begin{tabular}{|c|c|c|}
\hline Substrates & Enzyme source \\
\hline 2-Aryl-1,3-dithiolanes & Rabbit lung & Reference \\
\hline Alkyl $p$-tolylsulfides & Rabbit lung/mini pig liver \\
\hline Thiocarbamides & Rat liver & [63] \\
\hline Benzimidazoline-2-thiones & Rat liver \\
\hline 2-(Alkylthio)-1,3,4-thiadiazoles 2-(Alkylthio)-1,3-benzothiazoles & Human liver \\
\hline Thiouracil derivative & Rat / dog liver & {$[65]$} \\
\hline
\end{tabular}


decreased. Adrenal weight was increased and hypertrophy of the zona fascicularis of the adrenal gland was observed. Some increase in kidney weight was also noted. It is likely that the changes observed are secondary to the persistent decrease in cytochrome P450 activities. The authors concluded that the effects of daily 1-ABT administration "over a 13 week period were well-tolerated under controlled laboratory conditions".

Moorthy et al. reported that administration of 1-ABT to rats, followed by exposure for 24-. 28-, or 60-hours to $>95 \%$ oxygen caused the 1-ABT-treated animals to die between 48 and 60 hours, whereas no control rats exposed to similar hyperoxic conditions died at up to 60 hours of exposure [88]. 1-ABT thus potentiated hyperoxic lung injury.

\section{Analogues of 1-ABT}

A number of analogues of 1-ABT have been examined to explore the range of structures compatible with mechanism-based inactivation of P450 enzymes. Efforts to alter the core 1-ABT structure have yielded mixed results. Compounds 3 and $\mathbf{4}$ (Figure 6) cause catalysisdependent loss of the P450 content in microsomal incubations, but do not appear to result in the formation of a covalent heme adduct, while compound 2 causes NADPH-independent conversion of the P450 to a P420 chromophore [20].

Modifications of the aromatic hydrocarbon ring and of the exocyclic amino group, however, are tolerated. Thus, replacement of the benzene ring of 1-ABT by a naphthyl ring as in compound 7 (Table 2) yields an analogue that interacts with cytochrome $P 450$ in much the same way as 1-ABT [20], causing both catalysis-dependent loss of the P450 chromophore and accumulation of a hepatic pigment. Although the structure of the pigment was not established, it had properties very similar to those of the N,N'-bridged porphyrin adduct obtained with 1-ABT (Figure 2).

The N-mono- and N,N-diacetyl derivatives of 1-ABT, compounds 8 and 9, cause NADPH-dependent loss of P450 content and the formation in vivo of a porphyrin pigment analogous to that obtained with 1-ABT. The same is observed with the $\mathrm{N}$-methyl, $\mathrm{N}$-acetyl derivative 10, $\mathrm{N}$-methyl analogue 11, and the N-butyl derivative 12 $[20,22]$. A porphyrin pigment was formed in vivo with these agents, but its identity was not determined. Compounds 13-15 represent the introduction of even larger substituents on the exocyclic nitrogen. These agents, which are more lipophilic and are generally active at lower concentrations than 1-ABT, cause catalysis-dependent loss of both P450 content and catalytic activities. In the case of the N-benzyl derivative 13, it has been explicitly demonstrated that a hepatic pigment similar to that formed with 1-ABT is formed in phenobarbital-pretreated rats [20]. This indicates that inactivation by the N-benzyl derivative, as with 1-ABT itself, involves formation of a benzyne that adds to the P450 heme group. Although it is conceivable that the N-benzyl compound is first oxidized to 1-ABT, which then is the actual inactivating agent, it is more likely that benzyne formation is directly initiated from the $\mathrm{N}$-benzyl derivative by electron abstraction from the nitrogen.

Compound 5 (Figure 6), a putative possible intermediate in the inactivation mechanism of 1-ABT (Figure 5), does not cause detectable $\mathrm{P} 450$ loss [20]. This indicates that this N-hydroxyl compound is not an intermediate in the action of 1-ABT. The N-nitro compound 6 could not be properly evaluated because it is a powerful electron acceptor that interferes with the $\mathrm{P} 450$ assay and, upon administration to rats in vivo, causes asphyxia [20].

Analysis of the effects of compounds 13-15 suggests that, in addition to heme adduct formation, there are alternative, isoformdependent inhibitory mechanisms. Thus, incubation of these agents with liver microsomes from untreated, phenobarbital-induced, or $\beta$-naphthoflavone-induced guinea pigs led to the observation of a complex with an absorption maximum at approximately $455 \mathrm{~nm}$ [90]. This corresponds to the formation of a metabolite-intermediate (MI) complex comparable to that formed with other amines, an inference consistent with the fact that the complex was disrupted by addition of $50 \mu \mathrm{M}$ potassium ferricyanide or, in the case of 14 and 15 , by sedimentation and resuspension. The formation of this complex was highest with the microsomes from phenobarbital-induced guinea pigs, and was attenuated in the presence of $1 \mathrm{mM}$ glutathione. Interestingly, formation of this complex was not observed with pulmonary microsomes from guinea pigs or rabbits. Formation of the MI complex is therefore only observed with some P450 enzymes in some tissues. Further work suggested that mechanism-based inactivation was favored by CYP1A1 and CYP2B, and reversible inhibition by CYP1A2 [91]. The nature of this complex was not further characterized, but it was postulated that it might result from formation of an alkyl nitroso species according to the scheme in Figure 7. Coordination of the electron pair in the nitrogen of the nitroso group to the heme iron would then explain the MI complex. In any case, this process is ancillary and independent from that associated with the direct action of 1-ABT.<smiles>c1ccc2[nH]nnc2c1</smiles><smiles>Nn1nc2ccccc2n1</smiles>

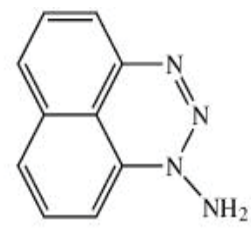<smiles>Nn1nnc2ccccc21</smiles><smiles>O=[N+]([O-])n1nnc2ccccc21</smiles>

6
Figure 6: Analogues of 1-ABT with variants of the core 1-aminobenzotriazole structure are not effective mechanism-based inactivating agents.

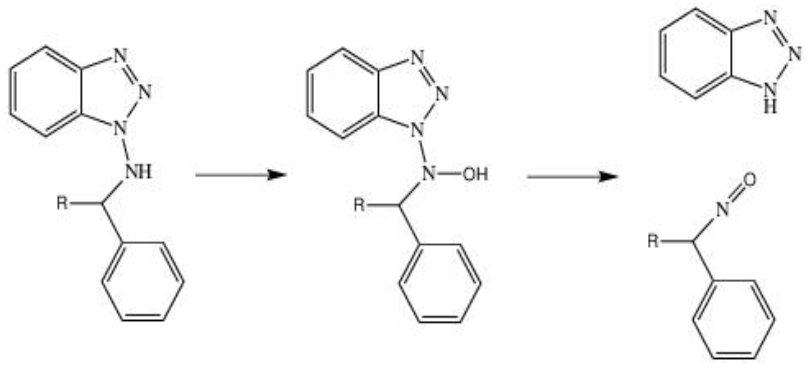

Figure 7: A possible mechanism for the formation of a nitroso compound that could coordinate to the heme iron of P450, resulting in observation of $\mathrm{MI}$ complexes. The reaction scheme shown is a modified version of that proposed by Sinal and Bend [90]. The R stands for $\mathrm{H}, \mathrm{Me}$, or Et, depending on whether it refers to experiments with compound 13,14 , or 15 (Table 2), respectively. 
Rat CYP2B1 is completely inactivated in vitro by incubation of liver microsomes with $1 \mu \mathrm{M}$ N-benzyl compound 13. Benzaldehyde, benzotriazole, 1-ABT, and an unknown metabolite of 13 tentatively assigned to a "dimer" of the inhibitor were isolated from these incubations [92]. However, the Gly478Ala mutant of CYP2B1 was not inactivated and only produced the "dimeric" metabolite. Modeling studies suggested that the Gly478Ala mutation prevented oxidation of the 1-amino group, favoring instead oxidation of the 7-benzyl carbon and preventing formation of the inactivating metabolite. Mechanistic studies of CYP2B1 inactivated by the N-benzyl derivative of 1-ABT indicated that the inactivated enzyme was reduced more slowly by NADPH-cytochrome P450 reductase [93]. The data also indicated that differences existed in the extent to which the metabolism of several compounds was inhibited. N-benzyl 1-ABT also inhibited the 7-ethoxyresorufin O-deethylase and 7-methoxyresorufin O-demethylase activities by 88 and 71\%, respectively, in microsomes from $\beta$-naphthoflavone-induced guinea pig heart [94]. These activities were attributed to CYP1A1.

Both enantiomers of $\mathrm{N}$-( $\alpha$-methylbenzyl)-1-aminobenzotriazole [14] inactivated guinea pig hepatic CYP2B and CYP1A enzymes, with small differences in enantiospecificity [95].

Inactivation of guinea pig lung and liver CYP1A1, CYP2B4, and CYP4B1 by the N-benzyl and N-( $\alpha$-methylbenzyl) analogues 13 and 14 has been compared by measuring changes in the oxidation of 7-ethoxyresorufin (CYP1A1), 7-pentoxyresorufin (CYP2B4) and 4-aminobiphenyl N-hydroxylation (CYP4B1) [96]. In uninduced and phenobarbital induced guinea pigs the order of inactivation was $2 \mathrm{~B} 1>1 \mathrm{~A} 1>>4 \mathrm{~B} 1$. However, in $\beta$-naphthoflavone induced animals, the a-methyl compound inhibited lung CYP2B4, whereas even at concentrations 100-fold higher, it did not inhibit CYP4B1 and CYP1A1. The a-methyl compound was also much more active in vivo in inactivation of lung CYP2B4 than of the liver enzymes. In contrast, 1-ABT exhibited little isoform or tissue specificity. The authors postulated that the lung specificity of the $\mathrm{N}$-substituted compounds $\mathbf{1 3}$ and $\mathbf{1 4}$ reflected selective absorption by the lipophilic aromatic amine uptake system of the lung. In these studies, inhibition by compounds 13 and 14 was not paralleled by comparable losses in P450 content, whereas with 1-ABT the activity and $\mathrm{P} 450$ losses were comparable. This indicates that the inhibition caused by the substituted 1-ABT analogues included mechanisms other than heme alkylation.

Inhibition of at least some cytochrome P450 enzymes by much lower concentrations of compounds 13-15 than of 1-ABT, and greater isoform and tissue selectivity, have also been reported in a number of studies [97-99]. Of particular note is the observation that N-benzyl 1-ABT inhibits CYP1A1 in guinea pig kidney in preference to the enzyme that oxidizes arachidonic acid, and in lung primarily inhibits epoxidation of arachidonic acid, whereas 1-ABT itself inhibits both epoxidation and $\omega$-hydroxylation [100,101]. N-( $\alpha$-methyl)-1-ABT has been shown to selectively inhibit dog CYP2B11 relative to CYP3A12 [102].

Incidentally, derivatives of 1-ABT obtained by laccase-catalyzed reaction of 1-ABT with 2,5-dihydroxybenzoic acid methyl ester and 2,5-dihydroxybenzoic acid ethyl ester were found to have low antimicrobial activities [103].

\section{1-ABT in Analysis of Xenobiotic Metabolism}

\section{Bioavailability and first pass metabolism}

The use of 1 -ABT in a rat in vivo pharmacokinetic screen has been proposed as a tool for determining the relative extent to which absorption and metabolism contribute to low oral systemic exposure of a drug [104]. The model drugs used in validating this approach were propranolol, metoprolol, and cimetidine. In another study, the low oral (19\%) bioavailability of an undefined drug in Sprague Dawley rats was examined by comparing bioavailability in rats pretreated with $50 \mathrm{mg} / \mathrm{kg}$ 1-ABT 2 hours prior to both intravenous and oral administration of the drug [105]. 1-ABT caused a $71 \%$ increase in plasma clearance, a $100 \%$ increase in half-life, and a marked increase in bioavailability. Similarly, a comparison of bioavailability of oral danazol in rats with and without 1-ABT pretreatment showed that the bioavailability of danazol rose from $2 \%$ to $60 \%$ and was primarily limited by first pass metabolism [106]. Comparison of the bioavailability of a $\beta$-glucuronidase inhibitor in mice before and after pretreatment with 1-ABT established that its low bioavailability (21\%) was due to first pass metabolism [107]. An investigation of intestinal permeability and first-pass metabolism of acetaminophen, verapamil, and midazolam using single-pass intestinal perfusion showed that $1-\mathrm{ABT}$ increased the intestinal availability of these three drugs to $0.8-0.85$ in cyanomologous monkeys, confirming that they are extensively metabolized in the intestine [108]. A significant increase in the exposure of mice to midazolam was observed when the mice were pretreated with 1-ABT [109]. The use of 1-ABT also demonstrated that intestinal metabolism, at least in part by CYP2J2, diminished the bioavailability in rats of AZ'0908, a prostaglandin E synthase-1 inhibitor [110]. Using a serial blood sampling method, the administration of 1 -ABT $(50-150 \mathrm{mg} / \mathrm{kg}) 2$ hours prior to a single intravenous dose of antipyrine $(20 \mathrm{mg} / \mathrm{kg})$ was shown to increase the AUC from 27.3 to upto $333 \mu \mathrm{g} \mathrm{h} / \mathrm{ml}$ and the half-life from 0.51 to up to 2.2 hours [111].

1-ABT can be used to potentiate (or "boost") the action of a drug by decreasing its P450 metabolism. Thus, a series of 5 -substituted 4 -anilinoquinazolines, potent inhibitors of the erbB2 receptor tyrosine kinase, inhibited tumor growth in a mouse xenograft model when 1-ABT was employed to potentiate their action [112]. In this instance, 1 -ABT increased exposure to the tumor inhibitors approximately 100 fold.

Human hepatocytes can be used to assay time-dependent inhibition of cytochrome P450 enzymes. These assays correctly distinguished the inactivation of CYP3A4 by 1-ABT and erythromycin from inhibitors that were not time-dependent: for 1-ABT, the values obtained were $\mathrm{K}_{\mathrm{I}}=22.0 \mu \mathrm{M}$ and $\mathrm{k}_{\text {inact }}=0.09 \mathrm{~min}^{-1}$ [113]. 1-ABT was employed in the development of this high throughput assay system [114,115].

\section{Clarification of oxidative mechanisms}

The conversion by rat liver microsomes of the esterified pesticide thiazopyr to the free acid is inhibited by $1-\mathrm{ABT}$ and is thus mediated by a cytochrome P450 enzyme rather than by an esterase (Figure 8 ) [116]. Using 1-ABT, cytochrome P450 catalysis in the endoplasmic reticulum was found in another instance to contribute to the instability of a TGR5 receptor agonist with a central amide bond [117]. A more exotic transformation in the metabolism of GNE- 892 by rats produces two ring-contracted pyrazole compounds as minor metabolites (Figure 8). This ring contraction is inhibited by $1-\mathrm{ABT}$ and is thus cytochrome P450-dependent [118].

1-ABT was recently used to establish that the deiimination of the sulfoximine moiety in the ATR inhibitor AZD6738 to a sulfoxide and sulfone, a nominally reductive event, is mediated by cytochrome P450 (Figure 9) [119]. A reasonable oxidative mechanism for this transformation was postulated. 


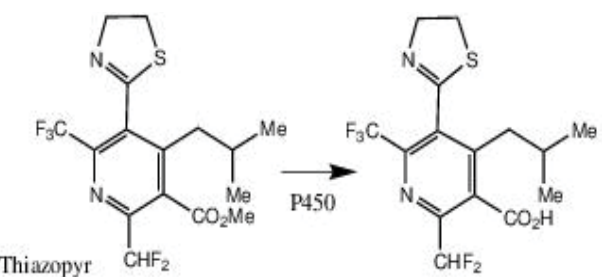

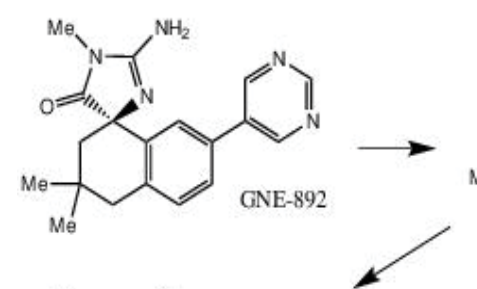

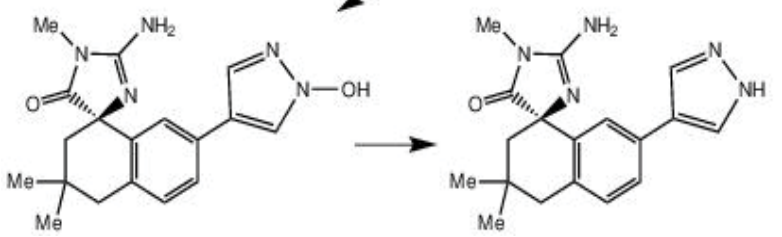

Figure 8: Metabolites of thiazopyr and GNE-892 produced by cytochrome P450

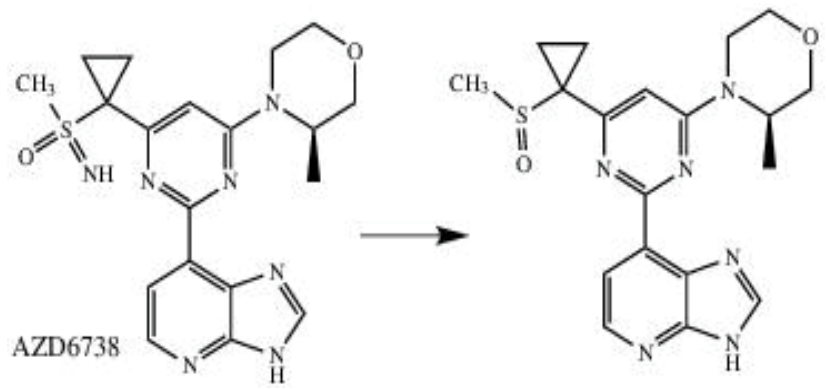

Figure 9: Cytochrome P450 catalyzed oxidation resulting in a reduced metabolite.

In contrast, the reductive metabolism of the dinitrobenzamide mustard anticancer prodrug PR-104, which is activated to its cytotoxic form in the liver, is not inhibited by $1-\mathrm{ABT}$, indicating that cytochrome $\mathrm{P} 450$ itself is not involved in this reductive transformation [120]. 1-ABT was similarly employed to establish that the metabolism of a vasoactive drug, SK\&F 86466, in isolated, perfused rat lungs was not mediated by cytochrome P450 enzymes [121]. In these studies, 1-ABT administered to the rats before the lung study was shown to suppress P450 activities completely without any effect on the metabolism of the drug. A comparison of the effects of 1-ABT and inhibitors of epoxide hydrolases on the metabolism of oprozomib, an oral proteasome inhibitor, confirmed that the major metabolic pathway was epoxide hydrolysis rather than P450-catalyzed oxidation [122].

\section{Oxidation of pharmaceutical agents}

The use of 1-ABT in studies of the action of a variety of agents is summarized in Table 3.

\section{1-ABT as a Probe of Physiological Processes}

\section{Fatty acid oxidation}

Cytochrome P450 enzymes oxidize fatty acids and these oxidative reactions can be inhibited by 1-ABT. HPLC analysis of the oxidation of radiolabeled lauric acid by control and clofibrate-induced rat liver microsomes showed that 1-ABT inhibits the oxidation of lauric acid to the $\omega-, \omega-1$, and $\omega-2$ hydroxylated derivatives [20,144,145]. Comparison with more specific inhibitors implied the presence of at least one lauric acid $\omega$-hydroxylase and two $\omega$ - 1 hydroxylases $[145,146]$. However, 1-ABT did not alter the ability of clofibrate to decrease serum triglyceride levels in rats, which showed that fatty acid hydroxylation was not critical for the antihyperlipidemic action of this drug [144]. Furthermore, work with primary hepatocyte cultures indicated that induction of peroxisomal $\beta$-oxidation and liver fatty acid binding protein is mediated by a 1-ABT-insensitive mechanism subsequent to P450 oxidation of long-chain fatty acids to dicarboxylic acids [147].

\section{Arachidonic acid oxidation}

The oxidation of arachidonic acid to both epoxyeicosatrienoic acids and 16- through 20-hydroxyeicosatetraenoic acids by pulmonary microsomes from $\beta$-naphthoflavone-induced guinea pigs was inhibited by more than $95 \%$ after preincubation with $1 \mathrm{mM} 1$-ABT [101]. Formation of the epoxide metabolites was attributed in this study largely to the guinea pig orthologue of CYP2B4. 1-ABT causes dose-dependent loss of renal cytochrome P450 content, arachidonic acid oxidation, and CYP4A protein content when administered intraperitoneally to Sprague-Dawley rats [148]. In the cortex and outer medulla, 1-ABT was a potent inhibitor of the formation of 19-hydroxyeicosatetraenoic acid (19-HETE) and 20-hydroxyeicosatetraenoic acid (20-HETE). The activity losses caused by 1-ABT returned to control levels after 72 hours. Interestingly, renal arachidonic acid epoxygenase activity was not impaired under the same conditions. A single dose of 1-ABT given to 7-week old spontaneously hypertensive rats caused an acute reduction in mean arterial pressure that persisted for at least 12 hours. The role of 20-HETE in this antihypertensive effect is supported by the finding that an analogue of 1-ABT, 1-hydroxybenzimidazole, which does not inhibit 20-HETE formation has no effect on mean arterial pressure [148]. A fluorescent 20-HETE HPLC assay, which distinguishes this metabolite from other HETEs, dihydroxyeicosatrienoic acids, and epoxyeicosatrienoic acids, was used to demonstrate that $1-\mathrm{ABT}$ reduces the excretion of 20-HETE in rats and inhibits its formation by renal microsomes [149]. In vivo, a daily $50 \mathrm{mg} / \mathrm{kg}$ injection of 1 -ABT to rats over five days greatly lowered the urinary excretion of 20-HETE and the ability of renal cortical microsomes to oxidize arachidonic acid to 20-HETE and epoxyeicosatrienoic acids [150-152]. These examples are part of an extensive body of data (Table 4) indicating that 1-ABT is a mechanism-based cytochrome $\mathrm{P} 450$ inactivating agent of the enzymes that oxidize arachidonic acid to its diverse metabolites.

\section{Estradiol}

As discussed in the section on 1-ABT toxicity, this inhibitor does not directly inhibit cytochrome P450 enzymes of the sterol biosynthetic pathway [51,52], although an in vivo study suggested that inhibition may occur via an indirect mechanism [53-56]. The further metabolism of estradiol, however, is mediated by $\mathrm{P} 450$ enzymes that are also involved in drug metabolism. This metabolism has a complicated effect on cell proliferation and growth, as shown in the summary of the studies of these effects carried out with the help of 1-ABT as a cytochrome P450 inhibitor (Table 5). 
Citation: Ortiz de Montellano PR (2018) 1-Aminobenzotriazole: A Mechanism-Based Cytochrome P450 Inhibitor and Probe of Cytochrome P450 Biology. Med Chem (Los Angeles) 8: 038-065. doi: 10.4172/2161-0444.1000495

Table 2: Analogues of 1-ABT shown to inactivate cytochrome P450 enzymes.

\begin{tabular}{|c|c|c|c|c|}
\hline Compound number & Analog & $\% \mathrm{P} 450$ loss in vitro & $\begin{array}{l}\text { Porphyrin pigment } \\
\text { in vivo }\end{array}$ & Reference \\
\hline 1 & 1-ABT & $86^{\mathrm{a}}$ & yes & [20] \\
\hline 7 & & $65^{\mathrm{a}}$ & yes & [20] \\
\hline 8 & & $32^{\mathrm{a}}$ & yes & [20] \\
\hline 9 & & $20^{\mathrm{a}}$ & yes & [20] \\
\hline 10 & & $10^{\mathrm{a}}$ & yes & [20] \\
\hline 11 & & $43^{\mathrm{a}}$ & yes & {$[20,22]$} \\
\hline 12 & & $37^{\mathrm{b}}$ & $n d^{d}$ & [22] \\
\hline 13 & & $\begin{array}{l}25^{\mathrm{c}} \\
30^{\mathrm{b}}\end{array}$ & $n d^{d}$ & {$[22,89]$} \\
\hline 14 & & $\begin{array}{l}31^{\mathrm{c}} \\
37^{\mathrm{b}}\end{array}$ & $\mathrm{nd}^{\mathrm{d}}$ & {$[22,89]$} \\
\hline 15 & & $2^{c}$ & $\mathrm{nd}^{\mathrm{d}}$ & [89] \\
\hline
\end{tabular}

aLoss of P450 content on incubation of phenobarbital-induced rat liver microsomes with $1 \mathrm{mM}$ inhibitor for 30 min.

bLoss of P450 content on incubation of $\beta$-naphthoflavone induced rabbit lung microsomes with $10 \mu \mathrm{M}$ inhibitor.

'Loss of P450 content on incubation of untreated guinea pig pulmonary microsomes with $10 \mu \mathrm{M}$ inhibitor for 45 min.

${ }^{\mathrm{d}} \mathrm{nd}=$ not determined 
Citation: Ortiz de Montellano PR (2018) 1-Aminobenzotriazole: A Mechanism-Based Cytochrome P450 Inhibitor and Probe of Cytochrome P450 Biology. Med Chem (Los Angeles) 8: 038-065. doi: 10.4172/2161-0444.1000495

Table 3: Consequences of the inhibition of 1-ABT-mediated P450 metabolism of a range of compounds.

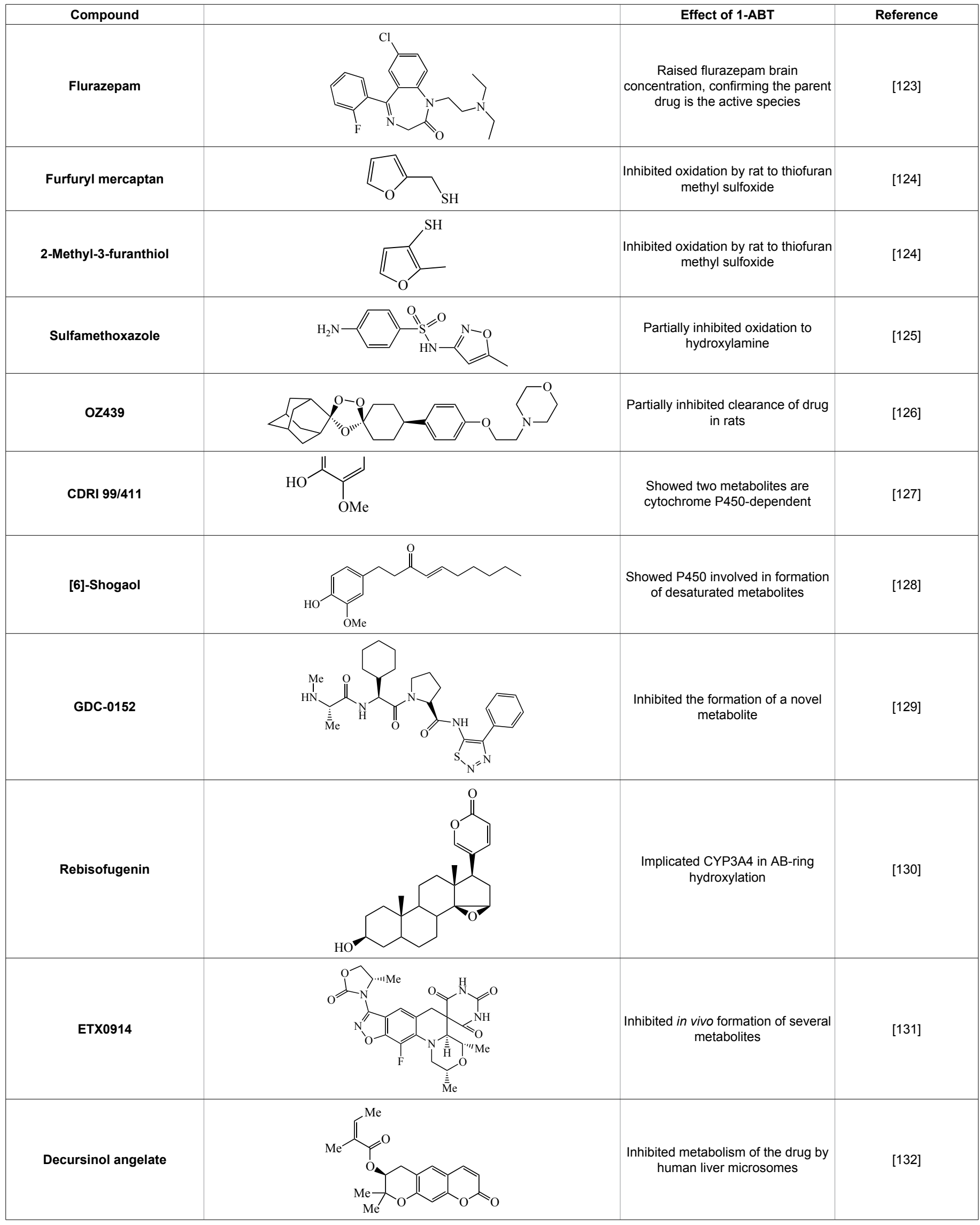


Citation: Ortiz de Montellano PR (2018) 1-Aminobenzotriazole: A Mechanism-Based Cytochrome P450 Inhibitor and Probe of Cytochrome P450 Biology. Med Chem (Los Angeles) 8: 038-065. doi: 10.4172/2161-0444.1000495

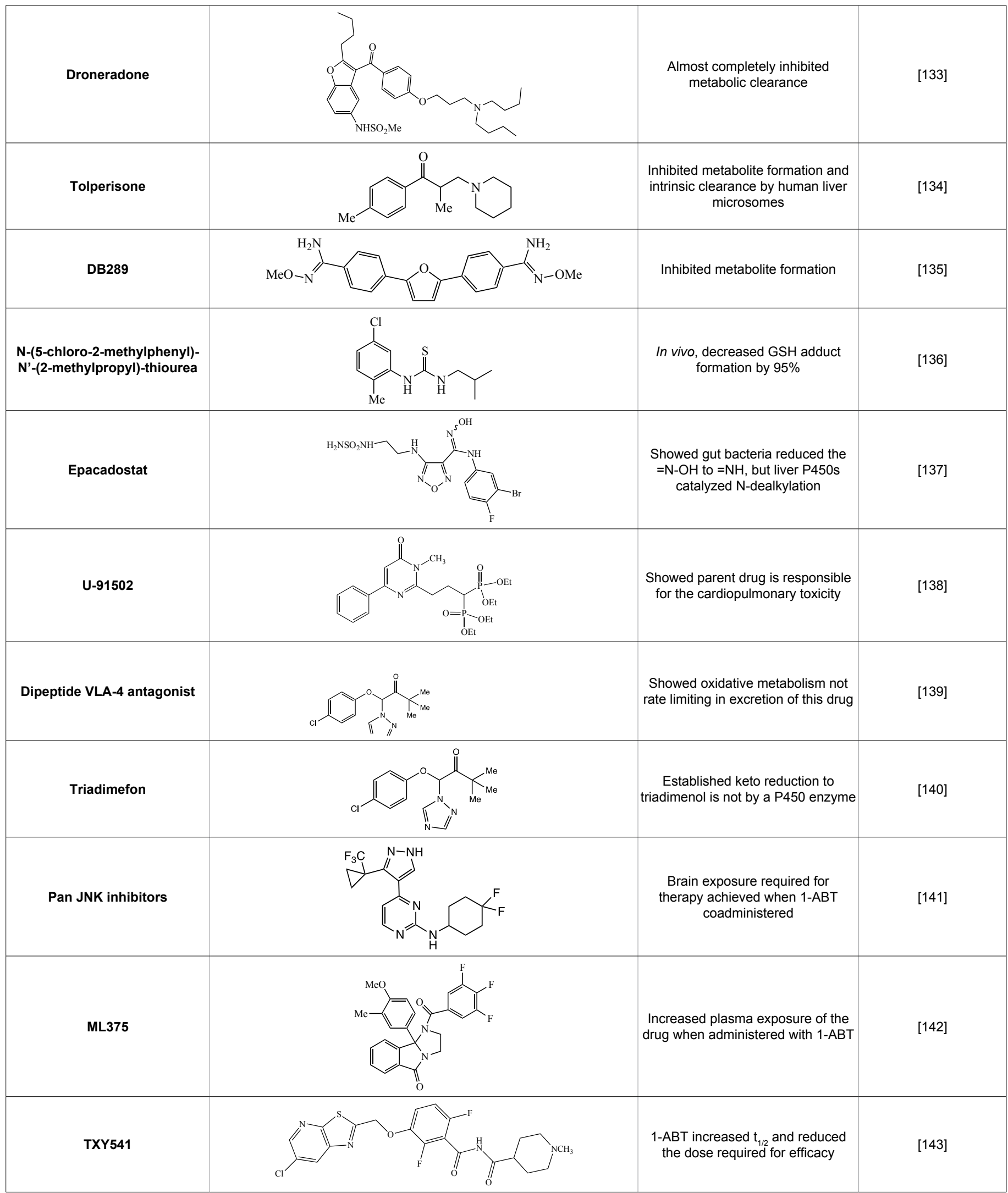


Citation: Ortiz de Montellano PR (2018) 1-Aminobenzotriazole: A Mechanism-Based Cytochrome P450 Inhibitor and Probe of Cytochrome P450 Biology. Med Chem (Los Angeles) 8: 038-065. doi: 10.4172/2161-0444.1000495

\begin{tabular}{|c|c|c|c|}
\hline Effector & System & Finding & Reference \\
\hline Endothelin-1 & $\begin{array}{l}\text { Foetal lambs, guinea } \\
\text { pigs }\end{array}$ & $\begin{array}{c}\text { 1-ABT inhibits contraction of ductus arteriosus by oxygen, implicating a P450- } \\
\text { based mechanism }\end{array}$ & [153] \\
\hline Acetylcholine & Isolated rat hearts & $\begin{array}{l}\text { 1-ABT inhibits cardiodepression by acetylcholine, implying a role for P450 and } \\
\text { EETs }\end{array}$ & {$[154]$} \\
\hline $\begin{array}{l}\text { Acetylcholine } \\
\text { leveromakalim }\end{array}$ & Rat mesenteric artery & $\begin{array}{l}\text { 1-ABT, unlike miconazole, did not influence endothelium-dependent } \\
\text { hyperpolarization }\end{array}$ & [155] \\
\hline $\begin{array}{l}\text { Endothelium-derived } \\
\text { hyperpolarizing factor (EDHF) }\end{array}$ & Rat mesenteric artery & $\begin{array}{l}\text { As 1-ABT did not counteract the effect, EDHF released by acetylcholine is not a } \\
\text { P450-derived arachidonic acid metabolite }\end{array}$ & [156] \\
\hline $\begin{array}{l}\text { High salt diet, } \\
\text { acetylcholine }\end{array}$ & Rats & $\begin{array}{l}\text { 1-ABT abolished the blood pressure increase due to intrarenal acetylcholine; } \\
\text { implicates } 20 \text {-HETE but not EETs in the process }\end{array}$ & [157] \\
\hline Bradykinin & Isolated rat hearts & $\begin{array}{l}\text { 1-ABT abolished cardiodepression by bradykinin, implying a role for P450 and } \\
\qquad 14,15-\mathrm{EET}\end{array}$ & [158] \\
\hline Bradykinin & Perfused rat kidney & $\begin{array}{l}\text { 1-ABT does not inhibit bradykinin increases in perfusion of the medulla mediated } \\
\text { by the NO system and } \mathrm{K}(\mathrm{Ca}) \text { channels }\end{array}$ & [159] \\
\hline Bradykinin & Isolated rat heart & 1-ABT prevented the decrease in left ventricular pressure caused by bradykinin & [160] \\
\hline Cyclosporin A, NO & Rats & $\begin{array}{c}\text { 1-ABT inhibited cyclosporin A mediated increases of 20-HETE, systolic blood } \\
\text { pressure, and renal damage }\end{array}$ & {$[161]$} \\
\hline NO & Rats & $\begin{array}{l}\text { 1-ABT blocked the renal vasodilatory response to NO and reduced its diuretic } \\
\text { and natriuretic effects }\end{array}$ & [162] \\
\hline ATP, NO & Rats & $\begin{array}{l}\text { 1-ABT and NO synthase inhibitors blunted ATP mediated increases in renal } \\
\text { arterial blood flow }\end{array}$ & {$[163]$} \\
\hline Endotoxin hypotension, NO & Rats & $\begin{array}{l}\text { 1-ABT diminished CYP4A activity but did not prevent the NO mediated decrease } \\
\text { in mean arterial pressure (MAP) }\end{array}$ & {$[164]$} \\
\hline NO & Rats, pregnant & $\begin{array}{l}\text { 1-ABT prevented the increases in systolic blood pressure caused by an NO } \\
\text { donor, suggesting a role for } 20 \text {-HETE }\end{array}$ & [165] \\
\hline $\mathrm{NO}, \mathrm{Na}^{+}-\mathrm{K}^{+}-2 \mathrm{Cl}^{-}$cotransport & MMDD1 cells & $\begin{array}{l}\text { 1-ABT reversed inhibition of } \mathrm{Na}^{+}-\mathrm{K}^{+}-2 \mathrm{Cl}^{-} \text {cotransport caused by } \mathrm{NO} \text {, implying a } \\
\text { role for a } \mathrm{P} 450 \text {-enzyme }\end{array}$ & {$[166]$} \\
\hline NO interaction & Rats, hypertensive & $\begin{array}{c}\text { 1-ABT attenuated elevation of blood pressure caused by L-NAME and lowered } \\
\text { organ damage }\end{array}$ & [167] \\
\hline $\mathrm{O}_{2}$ sensing, $\mathrm{K}^{+}$channel & $\begin{array}{l}\text { Rat carotid body type } \\
\text { I cells }\end{array}$ & $\begin{array}{l}\text { 1-ABT inhibited hypoxic depression of } \mathrm{K}^{+} \text {currents, suggesting a P450 enzyme is } \\
\text { involved }\end{array}$ & {$[168,169]$} \\
\hline $\begin{array}{l}\text { Arachidonic acid, } \mathrm{K}^{+} / \mathrm{Ca}^{2+} \\
\text { channels }\end{array}$ & $\begin{array}{l}\text { Rat carotid body type } \\
\text { I cells }\end{array}$ & $\begin{array}{l}\text { 1-ABT did not alter the effects of arachidonic acid on } \mathrm{K}^{+} \text {currents, suggesting they } \\
\text { are not mediated by a P450 enzyme }\end{array}$ & {$[170]$} \\
\hline EDHF & $\begin{array}{l}\text { Rat aorta smooth } \\
\text { muscle cells }\end{array}$ & $\begin{array}{l}\text { 1-ABT, unlike miconazole, does not interfere with } \mathrm{K}^{+} \text {channel activation, negating } \\
\text { a general P450 effect }\end{array}$ & [171] \\
\hline $\mathrm{K}^{+}$channels & $\begin{array}{l}\text { Rabbit portal vein } \\
\text { myocytes }\end{array}$ & $\begin{array}{l}\text { 1-ABT, unlike ketoconazole, had no effect on native KDR or RPV Kv1.5 current, } \\
\text { implying P450 inhibition not critical for ketoconazole effect }\end{array}$ & [172] \\
\hline $\mathrm{K}^{+}$channels & $\begin{array}{l}\text { Pulmonary arterial } \\
\text { myocytes }\end{array}$ & $\begin{array}{c}\text { 1-ABT reversibly inhibited steady-state } \mathrm{K}_{v}^{+} \text {channel currents and membrane } \\
\text { potential, but interpretation unclear }\end{array}$ & [173] \\
\hline Angiotensin & Rats & $\begin{array}{l}\text { 1-ABT inhibited the doubling of mean arterial blood pressure mediated by } \\
\text { angiotensin }\end{array}$ & {$[174]$} \\
\hline Angiotensin & Rats & $\begin{array}{c}\text { Chronic blockade of EETs and 20-HETE with 1-ABT attenuated the ANG II- } \\
\text { induced rise in MAP by } 40 \%\end{array}$ & [175] \\
\hline Angiotensin & Rats, hypertensive & $\begin{array}{l}\text { 1-ABT, angiotensin II, and endothelin individually reduced blood pressure to } \\
\text { similar levels, and more in combination }\end{array}$ & {$[176]$} \\
\hline Diabetes & Rats, diabetic & $\begin{array}{l}\text { 1-ABT attenuated vasoconstrictor responses to norepinephrine, endothelin-1, and } \\
\text { angiotensin II }\end{array}$ & {$[177]$} \\
\hline Postmenopause & Rats, hypertensive & $\begin{array}{l}\text { 1-ABT decreased blood pressure in postmenopausal, but not young, } \\
\text { spontaneously hypertensive rats, implicating a } 20 \text {-HETE contribution to } \\
\text { postmenopausal hypertension }\end{array}$ & [178] \\
\hline Pregnancy & Rats, pregnant & $\begin{array}{l}\text { 1-ABT decreased systolic blood pressure, urinary sodium, urinary } 20-\mathrm{HETE} \text {, renal } \\
20 \text {-HETE }\end{array}$ & {$[179]$} \\
\hline Pregnancy & Rats, pregnant & $\begin{array}{l}\text { 1-ABT decreased MAP in rats with reduced uterine perfusion pressure and } \\
\text { lowered both } 20-\mathrm{HETE} \text { formation and CYP4A expression }\end{array}$ & {$[180]$} \\
\hline
\end{tabular}


Citation: Ortiz de Montellano PR (2018) 1-Aminobenzotriazole: A Mechanism-Based Cytochrome P450 Inhibitor and Probe of Cytochrome P450 Biology. Med Chem (Los Angeles) 8: 038-065. doi: 10.4172/2161-0444.1000495

\begin{tabular}{|c|c|c|c|}
\hline $\begin{array}{l}\text { Diabetes, endothelin } \\
\text { streptozotocin }\end{array}$ & Rats, diabetic & $\begin{array}{c}\text { Blockade of CaMKII, Ras-GTPase or the production of } 20-\mathrm{HETE} \text { by } 1-\mathrm{ABT} \\
\text { normalized the altered vascular reactivity to ET-1 and carbachol in the carotid } \\
\text { artery of streptozotocin-induced diabetic rats }\end{array}$ & [181] \\
\hline Insulin resistance & Rats & $\begin{array}{l}\text { In the presence of testosterone, the 1-ABT inhibitable Cyp4A/20-HETE system } \\
\text { plays a key role in elevating blood pressure secondary to insulin resistance }\end{array}$ & [182] \\
\hline Natriuresis, Pressure response & Rats & $\begin{array}{c}\text { 1-ABT decreased the pressure-natriuretic response by } 50 \% \text { and renal formation } \\
\text { of } 20 \text {-HETE and ETAs by } 90 \% \text { and } 50 \% \text {, respectively }\end{array}$ & [183] \\
\hline Natriuresis, dopamine & Rats & $\begin{array}{l}1-\mathrm{ABT} \text { reduced the natriuretic response to dopamine by } 65 \% \text { and markedly } \\
\text { reduced urine flow and sodium excretion }\end{array}$ & [184] \\
\hline $\begin{array}{l}\text { Deoxycorticosterone (DOCA)- } \\
\text { salt }\end{array}$ & Rats & $\begin{array}{c}\text { 1-ABT reduced hypertension in a DOCA-salt model but did not prevent organ } \\
\text { hypertrophy and proteinuria }\end{array}$ & [185] \\
\hline 20-HETE vs EETs & Rats & $\begin{array}{l}\text { 1-ABT decreased renal artery flow without altering medullary perfusion, whereas } \\
\text { medullary NO increased }\end{array}$ & [186] \\
\hline $\begin{array}{l}\text { Renin } \\
\text { Hypertension }\end{array}$ & Ren-2 transgenic rats & $\begin{array}{l}\text { 1-ABT in Ren-2 transgenic rats decreased blood pressure and cardiac } \\
\text { hypertrophy, but not glomerulosclerosis, implicating P450 metabolites }\end{array}$ & [187] \\
\hline Pressure response & $\begin{array}{l}\text { Perfused dog renal } \\
\text { arcuate arteries }\end{array}$ & $\begin{array}{l}\text { 1-ABT partially inhibited the myogenic response to elevated perfusion pressure; } \\
\text { suggested a role for } 20-\mathrm{HETE} \text { in the myogenic response }\end{array}$ & [188] \\
\hline Balloon injury & Rat carotid arteries & $\begin{array}{l}\text { 1-ABT prevents the increase in } 20-\mathrm{HETE} \text { levels caused by balloon injury and } \\
\text { attenuated vascular smooth muscle cell remodeling, }\end{array}$ & [189] \\
\hline VEGF & Rat muscle & $\begin{array}{c}\text { 1-ABT blocked the increase in 20-HETE and angiogenesis caused by electrical } \\
\text { stimulation }\end{array}$ & [190] \\
\hline $\begin{array}{l}\text { Type II Phospholipase A2 } \\
\text { (sPLA2-II) }\end{array}$ & $\begin{array}{l}\text { Guinea pig alveolar } \\
\text { macrophages }\end{array}$ & $\begin{array}{l}\text { 1-ABT prevented the inhibition of sPLA2-II expression caused by low }(5 \mu \mathrm{M}) \text { but } \\
\text { not high }(30 \mu \mathrm{M}) \text { concentrations of arachidonic acid }\end{array}$ & [191] \\
\hline GABA receptor & HEK 293 cells & $\begin{array}{l}\text { 1-ABT did not block the inhibitory effect of arachidonic acid on currents due to the } \\
\qquad \alpha 1 \beta 2 \mathrm{y}^{2} \mathrm{GABA}(\mathrm{A}) \text { receptor }\end{array}$ & [192] \\
\hline Fetal bovine serum (FBS) & Murine $3 \mathrm{~T} 6$ fibroblasts & $\begin{array}{c}\text { 1-ABT decreased 12(S)-HETE levels, 3T6 fibroblast growth, and DNA synthesis } \\
\text { induced by FBS }\end{array}$ & [193] \\
\hline $\begin{array}{l}\text { Cholecystokinin octapeptide } \\
\text { (CCK) }\end{array}$ & $\begin{array}{l}\text { Rat pancreatic acinar } \\
\text { cells }\end{array}$ & $\begin{array}{l}\text { 1-ABT, unlike ketoconazole, did not alter baseline }\left[\mathrm{Ca}^{2+}\right] \text { or } \mathrm{CCK} \text {-evoked } \\
\text { oscillations }\end{array}$ & [9] \\
\hline Pulmonary vasodilation & $\begin{array}{l}\text { Isolated perfused rat } \\
\text { lung }\end{array}$ & $\begin{array}{l}\text { 1-ABT partially inhibited immediate arachidonic acid-induced pulmonary } \\
\text { vasodilation, suggesting a role for P450 enzymes }\end{array}$ & [194] \\
\hline Pulmonary vasodilation & Rat lung & $\begin{array}{l}\text { 1-ABT inhibited vasoconstriction caused by hypoxia and angiotensin II, but not } \\
\text { when 1-ABT was washed out first-conclude 1-ABT does not act through a P450 } \\
\text { mechanism }\end{array}$ & [195] \\
\hline Pulmonary vasoconstriction & $\begin{array}{l}\text { Isolated perfused } \\
\text { rabbit lung }\end{array}$ & $\begin{array}{l}\text { Hypoxia-induced vasoconstriction was inhibited by } 1-A B T \text {, but similar inhibition } \\
\text { was observed under normoxia with a thromboxane analogue. }\end{array}$ & [196] \\
\hline Ozone hyper-responsiveness & Mouse lung & $\begin{array}{c}\text { 1-ABT greatly attenuated airway sensitivity and the increases in 20-HETE caused } \\
\text { by ozone }\end{array}$ & [197] \\
\hline
\end{tabular}

Table 5: Effect of 1-ABT on estradiol-dependent pathways.

\begin{tabular}{|c|c|c|c|}
\hline Growth inhibition & Cardiac fibroblasts & $\begin{array}{c}\text { Inhibition by 1-ABT suggests estradiol inhibits cardiac fibroblast growth via an } \\
\text { estrogen receptor-independent pathway involving metabolism of estradiol to } \\
\text { methoxyestradiols }\end{array}$ & [198] \\
\hline Growth inhibition & $\begin{array}{l}\text { Human glomerular } \\
\text { mesangial cells }\end{array}$ & $\begin{array}{c}\text { Estradiol inhibited, serum-induced, proliferation of glomerular mesangial cells was } \\
\text { enhanced by P450 inducers and diminished by 1-ABT }\end{array}$ & [199] \\
\hline Growth inhibition & $\begin{array}{l}\text { Aortic vascular smooth } \\
\text { muscle cells }\end{array}$ & $\begin{array}{l}\text { Estradiol inhibited, serum-induced, proliferation of vascular smooth muscle cells } \\
\text { was enhanced by P450 inducers and diminished by } 1-\mathrm{ABT}\end{array}$ & [200] \\
\hline Growth inhibition & $\begin{array}{l}\text { Human coronary artery } \\
\text { smooth muscle cells }\end{array}$ & $\begin{array}{l}\text { Estradiol inhibited, serum-induced, proliferation of smooth muscle cells was } \\
\text { enhanced by P450 inducers and diminished by 1-ABT }\end{array}$ & [201] \\
\hline Growth inhibition & Human cardiac fibroblasts & $\begin{array}{c}\text { Estradiol inhibited, serum-induced, proliferation of human cardiac fibroblasts was } \\
\text { enhanced by P450 inducers and diminished by 1-ABT }\end{array}$ & [202] \\
\hline Cell proliferation & $\begin{array}{l}\text { Cultured rat vascular smooth } \\
\text { muscle cells }\end{array}$ & $\begin{array}{c}\text { 1-ABT increased the growth promoting effect of } 17 \beta \text {-estradiol by inhibiting formation } \\
\text { of } 2 \text { - and 4-hydroxyestradiol and reactive oxygen species }\end{array}$ & [203] \\
\hline Smooth muscle contraction & Rat aortic smooth muscle & $\begin{array}{c}17 \beta \text {-estradiol inhibition of phenylephrine-induced contraction was not prevented by } \\
1-\mathrm{ABT} \text {, suggesting a } \mathrm{P} 450 \text {-independent mechanism }\end{array}$ & [204] \\
\hline
\end{tabular}


Citation: Ortiz de Montellano PR (2018) 1-Aminobenzotriazole: A Mechanism-Based Cytochrome P450 Inhibitor and Probe of Cytochrome P450 Biology. Med Chem (Los Angeles) 8: 038-065. doi: 10.4172/2161-0444.1000495

Table 6: Some toxicological processes in which cytochrome P450 enzymes were implicated though inhibition by 1-ABT.

\begin{tabular}{|c|c|c|}
\hline Xenobiotic & End point inhibited & Reference \\
\hline Acebutolol & Antinuclear antibody production & [266] \\
\hline Amodiaquine & Toxicity of amodiaquine & [267] \\
\hline Carbamazepine & Protein-reactive metabolite formation & {$[268,269]$} \\
\hline Clopidogrel & Hepatic injury & [270] \\
\hline Efavirenz & $\begin{array}{c}\text { Inhibition of 8-hydroxy-efavirenz formation and hepatic } \\
\text { cell death }\end{array}$ & [271] \\
\hline Leflunomide & Cytotoxicity & [272] \\
\hline Leflunomide & Hepatotoxicity & [273] \\
\hline Methapyrilene & $\begin{array}{l}\text { Formation of reactive metabolite and genotoxic } \\
\text { potential }\end{array}$ & {$[274,275]$} \\
\hline Ticlopidine & Protein covalent binding and hepatotoxicity & [276] \\
\hline \multirow[t]{2}{*}{ Aflatoxin B1 } & Cytotoxicity to $3 \mathrm{~T} 3$ cells & [277] \\
\hline & Toxification due to CYP2C19 & [278] \\
\hline Capsaicin & Formation of toxic metabolite & [279] \\
\hline$\beta$-Carotene / $\beta$-apo-8'-carotenal & Formation of DNA strand breaks & [280] \\
\hline White snake root constituents & Cytotoxicity & [281] \\
\hline Aromatic and heterocyclic amines & Genotoxicity & [282] \\
\hline Benzene & Induction of micronuclei & [283] \\
\hline Butylated hydroxytoluene & Quinone methide formation & [284] \\
\hline Tetrahydrofuran & Hepatocellular proliferation & [285] \\
\hline Dimethylbenz[a]anthracene & Pre-B lymphocyte apoptosis & [286] \\
\hline Mono- and di-chlorobiphenyls & $\begin{array}{c}\text { Mutagenicity assays in Chinese hamster V79 cells } \\
\text { expressing CYP2E1 and SULT 1A1 }\end{array}$ & [287] \\
\hline N-(3,5-Dichlorophenyl)-succinimide & Nephrotoxic metabolite formation and renal damage & [288] \\
\hline $\mathrm{N}$-(3,5-Dichlorophenyl)-succinimide & Protein covalent binding and nephrotoxicity & [289] \\
\hline 3-(3,5-Dichlorophenyl)-2,4-thiazolidinedione & Hepatotoxicity & [290] \\
\hline 2-Nitropropane & Micronucleus and multinuclei formation & [291] \\
\hline N-Nitrosodimethylamine & Micronucleus and multinuclei formation & [291] \\
\hline NNK (4-(Methylnitrosamino)-1-(3-pyridyl)-1-butanone) & DNA strand breaks & [292] \\
\hline 5-Nitrobenzo[b]naptho[2,1-d]thiophenes. & DNA adduct formation & [293] \\
\hline $\begin{array}{l}\text { ( } \mathrm{N} \text {-(4-((1H-pyrrolo[2,3-b]pyridin-4-yl)oxy)-3- } \\
\text { fluorophenyl)-1-(4-fluorophenyl) 2-oxo-1,2- } \\
\text { dihydropyridine- 3-carboxamide) }\end{array}$ & Vacuolar degeneration and necrosis of adrenal cortex & [294] \\
\hline 2,3,7,8-tetrachlorodibenzo- $p$-dioxin & Decreased biliary excretion of the compound in rats & [295] \\
\hline
\end{tabular}




\section{Hypothermia}

Studies of the effects of hypothermia on the in vivo pharmacokinetics of midazolam in rats showed that the $\mathrm{K}_{\mathrm{m}}$ value for CYP3A2 remained unchanged at 37,32 , and $28^{\circ} \mathrm{C}$, but the $\mathrm{V}_{\max }$ decreased at the lower temperature [205]. 1-ABT was used in these studies to determine the contribution of this enzyme to the observed changes in pharmacokinetics.

\section{Other endogenous pathways}

SKF-93479, a histamine H2 antagonist, caused thyroid lesions in rats linked to increased plasma clearance of thyroxine and elevated TSH concentrations. Inactivation of cytochrome P450 in hepatocytes by 1 -ABT did not alter the effect of SKF-93479 on the accumulation of thyroxine, indicating that the enhancement was due to the parent drug and not a metabolite [206]. Temelastine (SK\&F 93944), a histamine H1 antagonist, caused thyroid lesions associated with hypertrophy and colloic depletion in rats [207]. Again, 1-ABT was used to establish that the effect of the drug was due to the parent and not an oxidatively generated metabolite. In another area, $\omega$-hydroxyceramides are the major lipids on the corneocyte envelop in the epidermis. 1-ABT was shown to inhibit incorporation of radiolabeled acetate into this lipid in cultured human keratinocytes [208]. 1-ABT also inhibited recovery of the skin when damaged in hairless mice. These results confirmed the importance of $\omega$-hydroxyceramides in determining the epidermal permeability of skin.

A V79-derived cell line overexpressing CYP2E1 and SULT1A1 was found to undergo much higher rates of spontaneous gene mutations and sister chromatid exchanges than control V79 cells [209]. These elevated rates were completely prevented by $1-\mathrm{ABT}$ or pentachlorophenol, a SULT1A1 inhibitor, suggesting that CYP1A1 in combination with SULT1A1 activates an endogenous molecule to a mutagenic product.

\section{Toxicity Studies}

\section{Sepsis}

Sepsis is a common, sometimes fatal condition during which cytochrome P450 enzymes are significantly downregulated due to a decrease in the levels of the AhR and Arnt receptors [210-212]. 1-ABT has provided evidence that cytochrome P450 enzymes are important for the prevention of hepatic dysfunction during sepsis [212-214]. Thus, treatment with 1-ABT enhanced the levels of proinflammatory cytokines in adult male Sprague-Dawley rats after induction of sepsis $[213,214]$. In sepsis induced by administration of low doses of zymosan, $58 \%$ mortality was observed when 1 -ABT was co-administered, in contrast to no mortality in the absence of 1-ABT [215].

\section{Acetaminophen/Phenacetin}

Intravenously administered phenacetin is oxidized in rats to acetaminophen, but this transformation is inhibited by pretreatment with 1-ABT [216], which changes the half-life of phenacetin from 34 to $230 \mathrm{~min}$. In contrast, in this same system 1-ABT has little effect on the clearance, half-life, or distribution of intravenously administered acetaminophen. Both intravenous and intraperitoneal pretreatment of rat with 1-ABT greatly inhibited the systemic clearance of phenacetin, with an intraperitoneal dose of $50 \mathrm{mg} / \mathrm{kg}$ of 1 -ABT resulting in $79 \%$ inhibition [85]. To determine if metabolism differences contributed to the finding that female Sprague-Dawley rats are more susceptible than male rats to acetaminophen-induced nephrotoxicity, incubations of hepatic and renal S9 fractions with radiolabeled acetaminophen in the presence of either 1-ABT or the reversible carboxyesterase inhibitor bis-( $p$-nitrophenyl)phosphate were carried out [217]. No sexdependent differences in covalent binding to protein of acetaminophen were observed and 1-ABT was found to inhibit covalent binding equally in both, whereas the carboxyesterase inhibitor had no effect on covalent binding. In a follow-up experiment, blood urea nitrogen was measured as an index of nephrotoxicity in rats after administration of radiolabeled acetaminophen. In this instance, pretreatment with either 1-ABT or tri-o-tolylphosphate, an irreversible carboxyesterase inhibitor, prevented elevation of blood urea nitrogen and decreased covalent binding [218]. Thus, both P450-catalyzed oxidation and deacetylation appear to contribute to nephrotoxicity. An analysis of the toxicity of acetaminophen to sinusoidal endothelial cells versus hepatocytes in $\mathrm{C} 3 \mathrm{H}-\mathrm{HEN}$ and Swiss Webster mice showed that it was more toxic to the sinusoidal cells, but the toxicity was suppressed by 1-ABT [219]. Studies with primary mouse hepatic parenchymal cells revealed that $1-\mathrm{ABT}$ prevented covalent binding and toxicity when acetaminophen was present at concentrations lower than $5 \mathrm{mM}$, but at higher concentrations a P450-independent toxicity mechanism also intervened that appeared to be related to the presence of $p$-aminophenol [220]. This second toxicity mechanism was alleviated by a carboxyesterase inhibitor.

\section{Cyclophosphamide}

Classical P450 inhibitors such as SKF-525A did not attenuate pulmonary thymidine incorporation, a marker of tissue injury, associated with administration of cyclophosphamide, whereas pretreatment with 1-ABT lowered thymidine incorporation into lung DNA on days 3 and 10, but not on day 7. Agents, such as indomethacin and aspirin, which inhibit arachidonic acid pathways independent of cytochrome P450, similarly reduced levels of thymidine incorporation in the lung. Although differences were found in the protective effects of these agents in liver and lung, it appears that oxidation of cyclophosphamide by the cytochrome P450 system is not essential for the development of pulmonary toxicity associated with cyclophosphamide [221]. Gene therapy to increase expression of CYP2B in tumors provides a strategy for increasing tumor rather than systemic toxicity of cyclophosphamide [222]. 1-ABT, which is more inhibitory to CYP2C than CYP2B cyclophosphamide activation, increases the $\mathrm{C}_{\max }$ and half-life of the activated anti-tumor metabolite of cyclophosphamide in rats [222].

\section{Nevirapine}

Nevirapine, a reverse transcriptase inhibitor, causes skin rash and hepatotoxicity. The 12-hydroxy metabolite causes the skin rash and deuteration of the 12-methyl in the parent drug, which inhibits 12-hydroxylation, suppresses rash formation [223]. However, blood levels of the deuterated compound were unexpectedly low due to formation of a quinone methide, which inactivates cytochrome P450. Comparable levels of nevirapine and the deuterated analogue were observed when the rats were pretreated with $1-\mathrm{ABT}$. The results led to the proposal that the quinone methide formed in the liver is responsible for the hepatoxicity of nevirapine, whereas the skin rash is due to formation of the 12-hydroxy metabolite in the skin, probably followed by sulfation to make it a more reactive species. The role of the quinone methide in liver toxicity was substantiated by a subsequent study, again using 1-ABT and the deuterated nevirapine analog, which showed that in vivo the quinone methide bound covalently to liver proteins, and in vitro specifically to rat CYP3A1 and CYP2C11, and human CYP3A4 (Figure 10) [224]. 


\section{Tienilic acid}

Tienilic acid is a hepatotoxic agent that forms a glutathione adduct (Figure 11), decreases glutathione levels, and upregulates toxicity marker genes [225]. All of these effects are blocked by pretreatment with an intraperitoneal dose of $66 \mathrm{mg} / \mathrm{kg}$ of $1-\mathrm{ABT}$. The metabolism of tienilic acid, as well as several other drugs, by human hepatocytes was shown to be inhibited by 1-ABT [226]. As tienilic acid itself inactivates CYP2C9, and other studies indicate that $1-\mathrm{ABT}$ is a good inactivator of most drug metabolizing forms of P450, but less so of CYP2C9 [41], a cocktail of tienilic acid and 1-ABT has been employed to approach pan-P450 inactivation [227]. A study of the cytotoxicity of bosentan in sandwich-cultured human hepatocytes showed that tienilic acid, as a CYP2C9-specific inhibitor, plus 1-ABT helped to preserve cell viability [228].

\section{Valproic acid}

To explore the mechanism by which valproic acid causes liver damage its effects on levels of $15-\mathrm{F}_{2 \mathrm{t}}$-isoprostane, a measure of oxidative stress, and the possible role of cytochrome P450 in the process, have been investigated [229]. Phenobarbital pretreatment was found to increase plasma and liver concentrations of $15-\mathrm{F}_{2 \mathrm{t}}$-isoprostane in valproic acid-treated rats by several fold. Cytochrome $\mathrm{P} 450$ metabolites of valproic acid were also increased. However, 1-ABT attenuated the formation of valproic acid metabolites, but did not lower the levels of $15-\mathrm{F}_{2 \mathrm{t}}$-isoprostane, suggesting that phenobarbital exacerbated liver damage by a mechanism independent of the P450 oxidation of valproic acid. An extension of this study confirmed that the (E)-2,4diene metabolite of valproic acid did not contribute to the toxicity of the parent compound in hepatocytes, as shown by the failure of 1-ABT to diminish the toxicity despite its inhibitory effect on formation of the metabolite [230].

\section{Loratadine}

Desloratadine, a nonsedating antihistamine, is converted in vivo to 3-hydroxydesloratadine, but efforts to reproduce this transformation in vitro were unsuccessful. More recent work showed that cryopreserved human hepatocytes yield both 3-hydroxydesloratadine and its $O$-glucuronide [231]. 1-ABT and gemfibrozil glucuronide, a CYP2C8 inhibitor, prevented 3-hydroxydesloratadine formation. Furthermore, the formation of this metabolite required both NADPH and UDPglucuronic acid, leading to the conclusion that 3-hydroxydesloratadine was generated by a sequence involving initial $\mathrm{N}$-glucuronidation, CYP2C8 hydroxylation of the glucuronide, and glucuronidase release of the 3-desloratadine metabolite (Figure 12). The glucuronide, indicated by Glu in the figure, could conceivably be located on the other nitrogen of the molecule.

In a different vein, 1-ABT was used to demonstrate that the druginduced phospholipidosis caused by loratadine in three-dimensional cultures of hepatocytes was due to the cytochrome P450-catalyzed formation of desloratadine [232].

\section{Precocene}

Precocene, a naturally occurring regulator of insect development, causes P450-dependent hepatic necrosis. Comparison of 24-hour cultures of rat hepatocytes with and without added calf serum showed that addition of serum decreased the toxicity of precocene and prevented glutathione loss [233]. However, although precocene was also toxic to 72-hour cell cultures, the effect of serum was attenuated and the toxicity was relatively insensitive to inhibition of P450 enzymes by 1-ABT, suggesting that a different mechanism of toxicity

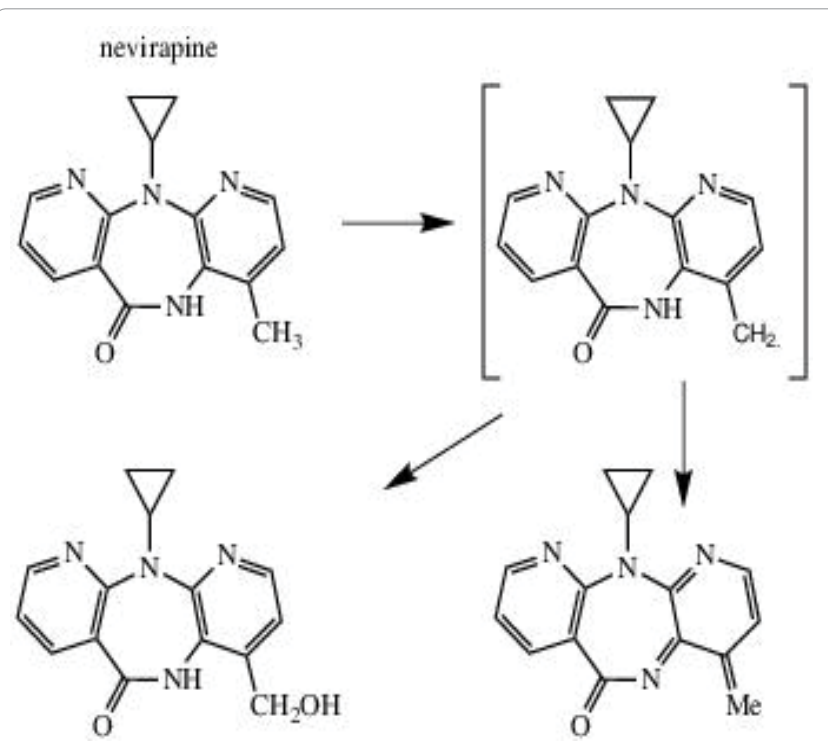

Figure 10: Metabolites of nevirapine formed by cytochrome P450 enzymes.

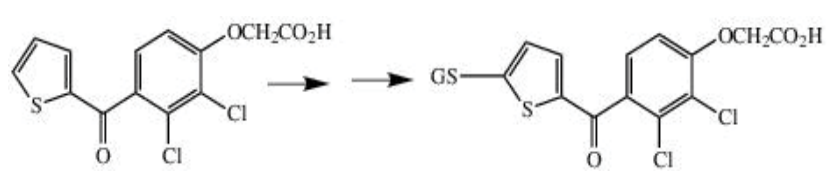

Figure 11: The cytochrome P450-catalyzed transformation of tienilic acid to a glutathione conjugate is inhibited by $1-\mathrm{ABT}$.<smiles>Clc1ccc2c(c1)CCc1cccnc1C2=C1CCNCC1</smiles>

Deslonatadine

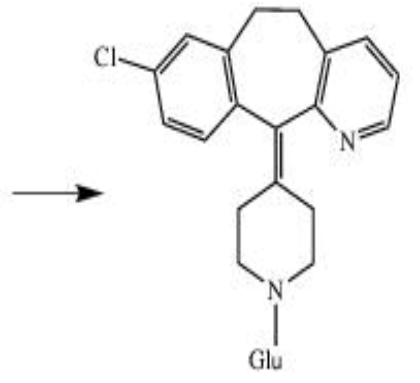

CYP2C8<smiles>Oc1cnc2c(c1)CCc1cc(Cl)ccc1C2=C1CCN(C2CCCCC2)CC1</smiles>

Figure 12: The hepatic metabolism of desloratadine elucidated with the help of 1-ABT. 
might be operative in the older cultures $[233,234]$. A later study of the metabolism of precocene by rat liver slices showed that differences exist in the metabolite profiles obtained with the slices versus in vivo in rats, particularly in the amount of dihydrodiol products generated from the epoxide metabolite (Figure 13) by epoxide hydrolases [235]. 1-ABT decreased the extent of metabolite formation and decreased the observed toxicity of precocene, and was more effective in doing so than ketoconazole and other isoform selective P450 inhibitors.

\section{3-Methylindole}

The pneumotoxicity of 3-methylindole in cattle, goats, sheep, horses, and other species appears to be mediated by a P450-generated electrophilic metabolite [236]. Thus, 1-ABT decreased 3-methylindole metabolism and its covalent binding to proteins in goat lung by 50 and $100 \%$ when present at a concentration of 10 and $100 \mu \mathrm{M}$, respectively. 1 -ABT also inhibited the toxicity of 3-methylindole in isolated rabbit lung cells [237,238], and abrogated the toxicity of 3-methylindole in human bronchial epithelial cells lines [239,240]. As 3-methylindole with a trideuterated methyl group is much less cytotoxic, it appears that oxidation of the methyl group produced the electrophilic metabolite involved in covalent binding and toxicity (Figure 14) [237].

\section{Acrylamide/acrylonitrile}

The oxidation by mice of acrylonitrile $\left(\mathrm{CH}_{2}=\mathrm{CHCN}\right)$ and acrylamide $\left(\mathrm{CH}_{2}=\mathrm{CHCONH}_{2}\right)$ to the epoxides glycidamide and cyano ethylene oxide, respectively, was suppressed by pretreatment with 1-ABT or when CYP2E1-null mice were employed. The data suggested that in mice CYP2E1 is the principal cytochrome P450 enzyme responsible for formation of these metabolites [44]. Other work showed that P450 enzymes other than CYP2E1 contribute to the oxidative metabolism of acrylonitrile and methacrylonitrile, as 1-ABT lowered the formation of cyanide derived from these compounds even in CYP2E1-null mice [241]. 1-ABT and CYP2E1-null mice were also used to show that CYP2E1 plays a major, but not exclusive, role in the oxidative metabolism of methacrylonitrile [45]. Acrylamide is a mutagen with clastogenic effects in mice. Pretreatment with 1-ABT prior to acrylamide administration greatly reduced this mutagenesis, providing strong support for the conclusion that the epoxide is the mutagenic metabolite [242]. However, 1-ABT was not found to decrease the morphological transformation of Syrian hamster embryo cells caused by acrylamide, a process that was inhibited by $\mathrm{N}$-acetylcysteine. This led the authors to postulate that acrylamide itself, not its oxidative metabolite, was responsible for cell transformation [243]. In another study, the incidence of adrenal, testicular, and thyroid neoplasia in rats upon chronic exposure to acrylamide was investigated [244]. Acrylonitrile was found to increase DNA synthesis in these tissues, but not in the liver or adrenal cortex, which are not target tissues for acrylamide carcinogenesis. Pretreatment with 1-ABT reduced DNA synthesis caused by acrylamide in the adrenal medulla, but not in the testicular mesothelium or thyroid. Acrylonitrile increases oxidative stress in rat brain and cultured rat glial cells. A study of the possible causes for this effect showed that acrylonitrile decreased the activity of catalase, and increased that of xanthine oxidase, but 1-ABTpretreatment counteracted these effects [245], suggesting that these protein alterations contribute to the increase in oxidative stress caused by acrylonitrile. Related studies in which 1-ABT was shown to decrease the extent of oxidative damage caused by acrylonitrile in rat brain concurred with the view that its P450-catalyzed oxidation was at the root of the oxidative damage [246].

Cis-2-pentenenitrile triggers permanent behavioral defects in

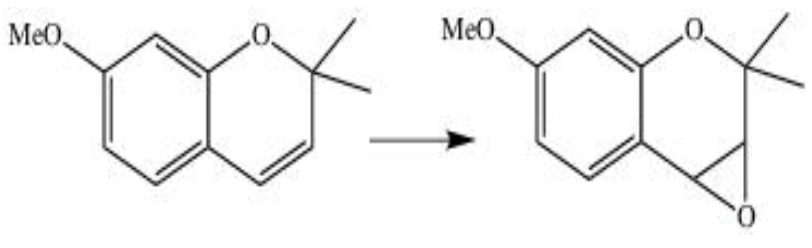

Figure 13: Epoxidation of precocene.

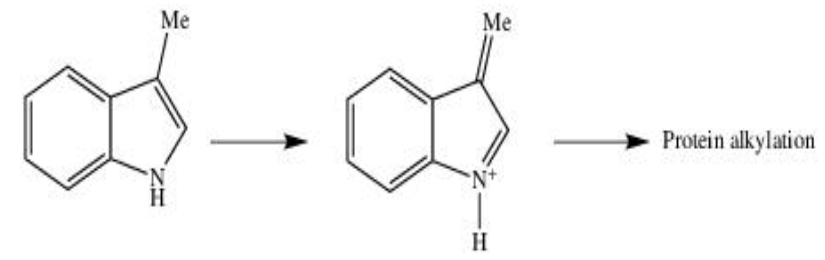

Figure 14: Oxidation of 3-methylindole to a reactive methylene iminium product that alkylates proteins.

rodents. These behavioral changes were prevented by pretreatment with 1-ABT, implicating oxidative metabolism of this substrate in its deleterious effects [247]. 1-ABT also decreased the mortality and vestibular toxicity of allylnitrile [248].

\section{Halocarbons}

A comparison of the toxicity of chloroform in male $\mathrm{B}_{6} \mathrm{C} 3 \mathrm{~F}_{1}, \mathrm{~Sv} / 129$ wild-type mice, and CYP2E1-null mice showed that the pathological changes caused by chloroform were only observed in wild-type mice. Furthermore, pretreatment of wild-type mice with 1-ABT completely protected against the cytotoxic effects of chloroform [249], leading to the conclusion that CYP2E1 was largely responsible for bioactivation of chloroform to a cytotoxic species. Dimethyl sulfoxide (DMSO) is known to confer some protection against chloroform-induced liver injury. To determine if this protection was due to inhibition of cytochrome P450 enzymes or some other phenomenon, the protective activities of DMSO and 1-ABT were evaluated in male Sprague-Dawley rats [250]. 1-ABT decreased covalent binding of ${ }^{14} \mathrm{C}$-chloroform to liver proteins by $35 \%$ and reduced the amount of radiolabel in blood 10 hours after radiolabeled chloroform administration by $50 \%$, whereas DMSO had no effect on these parameters even though it also protected the liver. Thus, DMSO confers protection by mechanisms other than inhibition of the bioactivation of chloroform.

The metabolism of inhaled 1-bromopropane by male F344 rats and $\mathrm{B} 6 \mathrm{C} 3 \mathrm{~F} 1$ mice resulted in exhaled radiolabeled $\mathrm{CO}_{2}$ and several glutathione-derived conjugates in the urine: $\mathrm{N}$-acetyl- $S$-propylcysteine, $\mathrm{N}$-acetyl-3-(propylsulfinyl)alanine, $\quad \mathrm{N}$-acetyl-S-(2-hydroxypropyl)cysteine, 1-bromo-2-hydroxypropane-O-glucuronide, $\mathrm{N}$-acetyl-S-(2oxopropyl)cysteine, and $N$-acetyl-3-[(2-oxopropyl)sulfinyl]alanine (Figure 15) [251]. In rats pretreated with 1-ABT, oxidative metabolism was decreased and the single urinary metabolite was that formed by glutathione displacement of bromide from the parent compound. 1-Bromopropane also has neurotoxic effects that are difficult to study in vivo due to the hepatotoxicity of the compound. Administration of 1 -ABT $(50 \mathrm{mg} / \mathrm{kg})$ to rats for three days inhibited $92-96 \%$ of the hepatic microsomal CYP2E1 activity, but only $62-64 \%$ of the same activity in brain microsomes. Under these conditions, it was possible to administer higher doses of 1-bromopropane and to examine their 
effect on the brain [252].

1,1-Dichloro-2,2-bis(4'-chlorophenyl)ethane

(DDD), 1,2-dibromoethane, and trichloroethylene are toxic to rabbit lung Clara cells, alveolar type II cells, and alveolar macrophages [253]. 1-ABT diminished the cytotoxicity of DDD and 1,2-dibromoethane to Clara cells, indicating that cytotoxic metabolite formation was mediated, at least in part, by cytochrome P450 enzymes.

The oxidative metabolism of trichloroethylene, a carcinogen present in the environment, was suggested by in vitro studies to be mediated by CYP2E1. To better assess the role of this enzyme, the metabolism of trichloroethylene in wild-type and CYP2E1-null mice was investigated [254]. The excretion of trichloroethylene as urinary metabolites and $\mathrm{CO}_{2}$ was much lower, and excretion of the parent compound higher, in the CYP2E1-null than wild-type mice. Pretreatment of both types of mice with 1-ABT inhibited the metabolism of trichloroethylene. These results indicated that CYP2E1 is important in trichloroethylene metabolism, but other P450 enzymes also make a contribution.

\section{Oxidative stress}

Pretreatment with 1-ABT attenuated the DNA fragmentation and cell death caused by 3-amino-1,2,4-triazole plus mercaptosuccinic acid in primary cultures of rat hepatocytes. This led to the conclusion that endogenous oxidative stress was directly related to the activity of cytochrome P450 enzymes [255]. The role of cytochrome P450, particularly CYP2E1, in the cellular injury caused by ethanol has been examined in rats, Cyp2e1-knockout mice, and p47(phox)-null mice lacking nicotinamide adenine dinucleotide phosphate oxidase [256]. The extent of oxidative DNA adducts, mutagenic apurinic/ apyrimidinic sites, and expression of DNA repair genes was measured. Ethanol caused an increase in these parameters in the wild-type rat and mice, and the p47(phox)-null mice, but not in the Cyp2e1-null mice. The increase in DNA repair genes was completely abolished by pretreatment with 1-ABT, implicating CYP2E1 and possibly other cytochrome P450 enzymes in ethanol-induced liver injury. The story is not simple, however, as an earlier study by the same group indicated that $1-\mathrm{ABT}$ did not prevent oxidative stress-associated liver injury in rats and mice caused by alcohol, as judged by examination of liver pathology [86]. Interestingly, vitamin E and 1-ABT offered protection against oxidative stress, hepatic apoptosis, and necroinflammation associated with non-alcoholic steatohepatitis [257].

Schisandrin B (Figure 16) from the fruit of Schisandra chinensis, a traditional Chinese medicine, protects against $\mathrm{CCl}_{4}$-induced hepatotoxicity and myocardial ischemia-reperfusion injury in rodents by enhancing mitochondrial glutathione status and inducing expression of the heat shock proteins Hsp25 and Hsp70 [258,259]. The finding that 1-ABT pretreatment significantly delays the in vivo time-course of the Schisandrin B-induced glutathione and Hsp25/70 responses in Balb/c mice suggests that cytochrome P450 enzymes facilitate the generation of reactive oxygen species in this system [259].

To determine whether cytochrome P450 enzymes contribute in vivo to oxidative stress through the production of reactive oxygen species, various cytochrome P450 inducers ( $\beta$-naphthoflavone, phenobarbital, Aroclor 1254, isoniazid, pregnenolone 16a-carbonitrile, and clofibrate) were examined in male Sprague-Dawley rats with and without pretreatment of the rats with 1-ABT [260]. Aroclor 1254 and phenobarbital, but not the other agents, enhanced the formation of malondialdehyde and $\mathrm{H}_{2} \mathrm{O}_{2}$ formation as well as NADPH oxidation both in vitro and in vivo. These two agents also increased the formation of F2-isoprostanes, which are markers of oxidative stress, and these

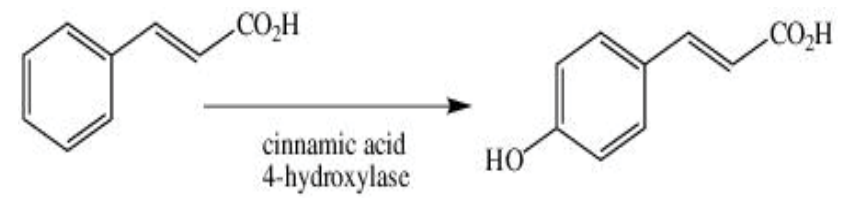

Figure 15: Oxidation of cinnamic acid by cinnamic acid 4-hydroxylase in the biosynthesis of phenylpropanoids in plants

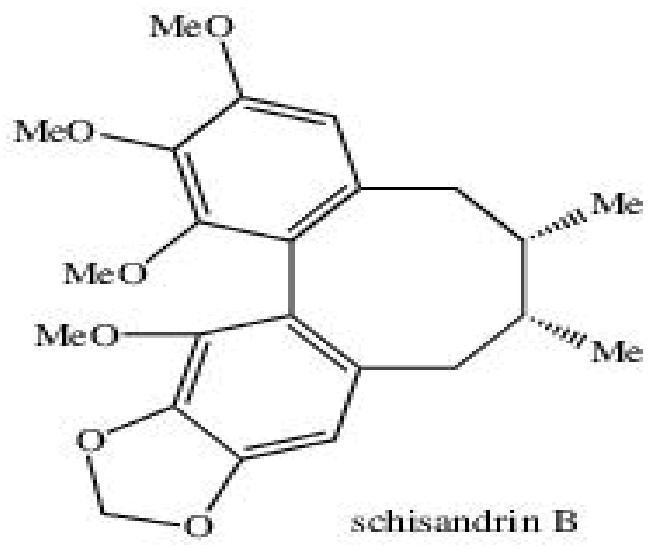

Figure 16: Structure of schisandrin B.

changes were attenuated by pretreatment with 1-ABT.

Methyl 3-(4-nitrophenyl)propiolate induces tumor cell apoptosis [261]. 1-ABT inhibited the formation of reactive oxygen species and cell apoptosis, implying a role for cytochrome P450 enzymes in the process.

\section{Free radical formation}

1-ABT has been used to rule out a role for cytochrome P450 in the formation of certain carbon radicals. Thus, neither 1-ABT nor CO attenuated the amplitude of the ESR spectrum of the phenyl radical produced in incubations of rat hepatic microsomes or cecal microflora with 1,3-diphenyl-1-triazene [262]. Phenyl radical formation, however, was decreased by antibodies to NADPH cytochrome P450 reductase, pointing to a reductive role of this protein in radical formation. 1-ABT and $\mathrm{CO}$ also did not attenuate the formation of phenyl radicals from diazoaminobenzene in incubations with liver microsomes. Furthermore, the radicals were formed on incubation of diazoaminobenzene with NADPH cytochrome P450 reductase, confirming a role for this enzyme rather than cytochrome $\mathrm{P} 450$ in the process [263]. In contrast, 1-ABT did inhibit the formation of the $\mathrm{CO}_{2}$ radical in the metabolism of sodium formate. However, allopurinol, an inhibitor of xanthine oxidase, also inhibited this reaction, which suggested that $\mathrm{H}_{2} \mathrm{O}_{2}$ was involved in the process [264]. This inference is supported by the finding that 3 -aminotriazole, a catalase inhibitor, significantly increased the level of spin trapped $\mathrm{CO}_{2}^{-}$radical. As noted earlier, exposure for 24-. 28-, or 60-hours to greater than $95 \%$ oxygen after administration of 1-ABT to rats resulted in the death of the 1-ABT-treated animals between 48 and $60 \mathrm{hr}$, whereas no control rats exposed to similar hyperoxic conditions died at up to 60 hours of exposure [88]. 1-ABT thus markedly potentiates hyperoxic lung and brain injury. In accord with this, the inhibition by 1-ABT of oxygen radical production by CYP2E1 in the brain of mice, assayed as the delay in the onset of convulsions in a hyperbaric chamber, was not effective 
and had undesirable side-effects [265].

\section{Other uses of 1-ABT in analysis of xenobiotic toxicology}

Many studies have been carried out that employ 1-ABT as a tool to elucidate the roles of cytochrome P450 enzymes in xenobiotic and drug toxicological processes. A summary of these is presented in Table 6 . On the other hand, some toxicological processes have not been found to involve cytochrome P450, as 1-ABT did not inhibit them, and these results are summarized in Table 7.

\section{Non-Mammalian P450 Enzymes}

\section{Plant P450 enzymes}

Endogenous substrates: Cinnamic acid 4-hydroxylase is a cytochrome P450 enzyme involved in phenylalanine metabolism and the biosynthesis of phenylpropanoids in plants (Figure 15). 1-ABT efficiently inactivated this enzyme in Helianthus tuberosus (Jerusalem artichoke) [58], but much more slowly inactivated the enzyme responsible for the hydroxylation of lauric acid. 1-ABT also exhibited a low activity for inactivation of the lauric acid $\omega$-hydroxylase of Vicia sativa L cv. Septimane, in contrast to the inactivation caused by 11-dodecynoic acid [301]. Microsomes from marine microalgae were have P450 enzymes that oxidize cinnamic acid, fatty acids, 3-chorobiphenyl, and isoproturon, and 1-ABT was specifically shown to abolish the oxidation of 3-chlorobiphenyl in intact cells [302].

The flavonoid 3',5'-hydroxylase of petunia hybrid flowers was inhibited by both 1-ABT and the growth regulator tetcyclasis [303]. In a more detailed study in Solanum lycopersicum (tomato), 1-ABT was shown to strongly inhibit the formation of flavonoids such as caffeic acid, kaempferol, and quercetin [304]. This is consistent with inhibition of cinnamic acid 4-hydroxylase. Furthermore, 1-ABT caused the accumulation of 9,12,13-trihydroxy-10(E)octadecanoic acid (Figure 17), probably by blocking further oxidative metabolism of this intermediate, whereas tetcyclacis completely suppressed its formation. These results provided clear evidence for differential roles of P450 enzymes in tomato plants.

The oxidation of tabersonine to hörhammericine in Catharanthus roseus hairy root cultures (Figure 18) was inhibited by 1-ABT, although it did not appear to inhibit the formation of lochnericine [305]. In contrast, clotrimazole inhibited the formation oflochnericine, indicating that different P450 enzymes catalyze these two transformations. Both agents inhibited the growth of the root cultures. Inhibition of these reactions is of potential importance in biotechnological channeling of tabersonine into the production of vindoline and the anticancer agents derived from it.

Xenobiotic metabolism: 1-ABT strongly, but differentially, inhibited the O-dealkylation of 7-ethoxycoumarin and 7-ethoxyresorufin by microsomes from manganese-induced Jerusalem artichoke, implying the action of two different P450 enzymes [306].
1-ABT has found wide use in studies of the metabolism of herbicides by plants and the role of this process in herbicide resistance. Thus, 1-ABT inhibits the metabolism of chlortoluron and isoproturon and synergizes the activities of these agents in wheat [84,307]. It also inhibits the metabolism of diclofop in wheat, but less effectively than tetcyclasis [308]. Work with suspension cultures of soybean (Glycine $\max (\mathrm{L}$.) Merr.) and rice (Oryza sativa L.) demonstrated that 1-ABT inhibited the metabolism of the herbicide bentazon in rice, although the data suggested that it could also reduce the uptake of bentazon by the cells [309]. The oxidation of bentazon (Figure 19) was also inhibited by $100 \mu \mathrm{M} 1-\mathrm{ABT}$ in maize cell suspension cultures, although less effectively than inhibition by the alternative P450 inhibitors tetcyclacis, phenylhydrazine, and piperonyl butoxide [310]. 1-ABT also synergized the activity of the herbicides clodinafop, haloxyfop, and fenoxaprop by inhibiting their P450 metabolism in blackgrass (Aloecurus myosuroides Huds.) [311]. Analysis of the metabolism of cinnamic acid, lauric acid, metolalchlor, bentazon, and diazinon by microsomes from grain sorghum (Sorghum bicolor (L.) Moench) demonstrated differential inhibition of the metabolism of these agents by tetcyclacis, piperonyl butoxide, 1-ABT, SKF-525A, and tridiphane [312]. Resistance to the herbicidal activity of metamitron (Figure 19) has been observed in the weed Chenopodium album (common lambsquarters). A study of the resistant and sensitive strains of this weed taken from sugar beet fields demonstrated that the resistance was due to enhanced metabolism of metamitron in the resistant strains [313]. 1-ABT inhibited this metabolism, even though piperonyl butoxide did not. 1-ABT was used to establish that the tolerance of Agrostis stolonifera (creeping bentgrass) to the herbicide topramezone is due to rapid metabolism of the herbicide [314].

1-ABT was used to establish that 4-monochlorobiphenyl, an environmental pollutant, is metabolized in poplar trees by cytochrome P450 enzymes [315].

\section{Fish P450 enzymes}

The inhibition of lauric acid $\omega-1$ hydroxylation, 7,12-dimethylbenz[a]anthracene hydroxylation, and progesterone $6 \beta$-hydroxylation in trout was examined using several inhibitory agents [316]. These activities were used as functional markers for the trout enzymes CYP2K1, CYP1A1, and CYP3A27, respectively. 1-ABT only slightly inhibited dimethylbenz[a]anthracene hydroxylation, but potently inhibited testosterone $6 \beta$-hydroxylation.

Diazinon is an organophosphate pesticide that is converted to a metabolite in which the sulfur attached to the phosphorus is replaced by an oxygen atom. This metabolite is a more potent inhibitor of acetycholinesterase than diazinon itself. In early life stages of medaka (Oryzias latipes), 1-ABT decreased acetycholinesterase inhibition, presumably by inhibiting the oxidation of diazinon to the more toxic metabolite [317].

The absence of inhibition by 1-ABT provided evidence that sulfoxidation of the thiourea herbicide eptam by liver microsomes

Table 7: Some toxicological processes not inhibited by 1-ABT and therefore unlikely to involve cytochrome P450 enzymes as active participants

\begin{tabular}{|c|c|c|}
\hline Xenobiotic & End point not inhibited & Reference \\
\hline Dapsone & $\begin{array}{c}\text { Formation of protein adducts in normal human } \\
\text { epidermal keratinocytes }\end{array}$ & [296] \\
\hline MRL-A & Formation of protein adduct & [297] \\
\hline Nimesulide & Toxicity to human and rat primary hepatocytes & [298] \\
\hline p-Aminophenol & [299] & tubules \\
\hline Carbaryl, Quinalphos, Benomyl Carbendazim & Cytotoxicity to Fa32 and human Hep G2 cells & \\
\hline
\end{tabular}


from striped bass was mediated by a flavoprotein monooxygenase rather than by a cytochrome P450 enzyme [318].

\section{Insect P450 enzymes}

1-ABT, which caused a loss of spectroscopically measurable cytochrome $\mathrm{P} 450$ and the accumulation of an N-N-bridged porphyrin in housefly microsomes [83], potentiated the activity of a carbamate insecticide in live houseflies. Based on evidence that methanol oxidation in Drosophila melanogaster is partially mediated by cytochrome P450 enzymes, the effect of 1-ABT and other enzyme inhibitors on methanol toxicity has been evaluated [319].

\section{Fungal and microbial P450 enzymes}

Endogenous substrates: Inhibition of the growth of Fusarium on cereals and their production of mycotoxins is desirable, as it results in loss of crop yield and poses a health threat to livestock and humans. 1-ABT was shown to inhibit production of the toxin 3-acetyldeoxynivalenol and the growth of the mycelia of Fusarium graminearum 4528 [320].

The antimicrobial sesquiterpenes enokipodins A, B, C, and D are obtained from mycelial cultures of the edible mushroom Flammulina velutipes. Studies of the biosynthesis of these agents using 1-ABT as a probe led to identification of three intermediates (shown in the boxes) in the biosynthetic sequence (Figure 20) [321].

A strain of Rhodococcus erythropolis developed by using $\beta$-myrcene as the sole carbon source showed that the major product formed by the cells from this precursor was geraniol [322]. 1-ABT decreased the production of geraniol by $73 \%$.

Xenobiotics: 1-ABT has been used to implicate cytochrome P450 enzymes in the degradation by white-rot fungi of many compounds. In Phlebia lindtneri, this included the demonstration that P450 enzymes participate in the degradation of dibenzo-p-dioxin, dibenzofuran, diphenyl ether, chloronaphthalenes, and polycyclic aromatic hydrocarbons $[323,324]$.

1-ABT inhibited the degradation of various chemicals by Phanerochaete chrysosporium and related species, including diclofenac and mefenamic acid [325], ketoprofen [326], norfloxacin and ciprofloxacin [327], diuron [328], and dibenzyl sulfoxide [329]. The growth of $P$. chrysosporium on diesel fuel was inhibited by 1-ABT, indicdating that P450 enzymes are involved in the utilization of this carbon source for biomass production [330].

The degradation of xenobiotics by Trametes versicolor, another white-rot fungus, was also inhibited by $1-\mathrm{ABT}$, pointing to the involvement of cytochrome $\mathrm{P} 450$ enzymes in the degradative pathways. This included the degradation of trichloroethylene [331], 1,2,3- and 1,2,4-trichlorobenzenes [332], ibuprofen [333], naproxen [334], and diclofenac [335] Pleorotus ostreatus oxidizes phenanthrene to phenanthrene trans-9,10-diol and this degradation is inhibited by 1-ABT [336].

1-ABT inhibited the metabolism by the filamentous fungus Cunninghamella elegans of phenanthrene [337], dibenzothiophene [338], and amitriptyline [339]. 1-ABT inhibited the oxidation of 4-(cyclohexylamino)benzophenone and other organic compounds by Beauveria bassiana [340]. A comparison of the product distribution obtained with this inhibitor versus other inhibitors indicated the involvement of more than one P450 enzyme. The oxidation of adamantine by Streptomyces griseoplanus was inhibited by $1-\mathrm{ABT}$ [341], as was the degradation of 2,5-dimethylpyrazine by Rhodococcus

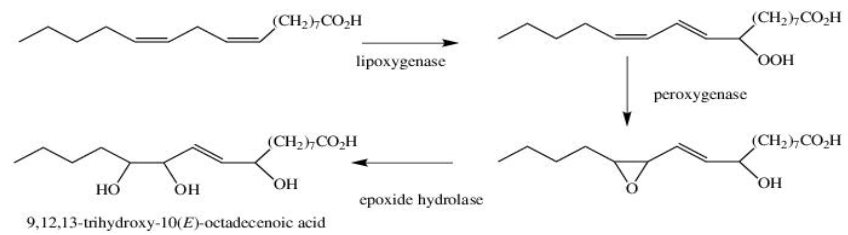

Figure 17: Formation of 9,12,13-trihydroxy-10(E)-octadecenoic acid in Solanum lypoersicum (tomato).

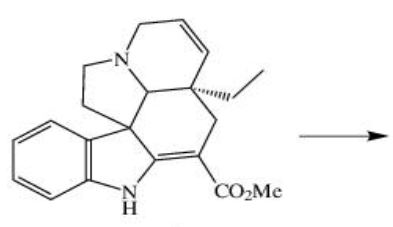

Tabersonine<smiles>CC(=O)C1=C2Nc3ccccc3C23CCN2CC=CC(C(C)O)(C1)C23</smiles>

19-Hydroxytabersonine

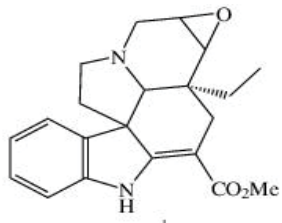

Lochnericine

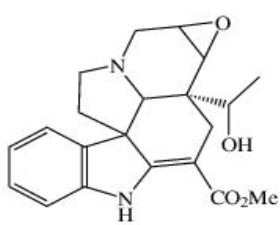

Hörhammericine
Figure 18: Pathways for the biosynthesis of hüorhammericine from tabersonine in the biogenesis of vindoline.

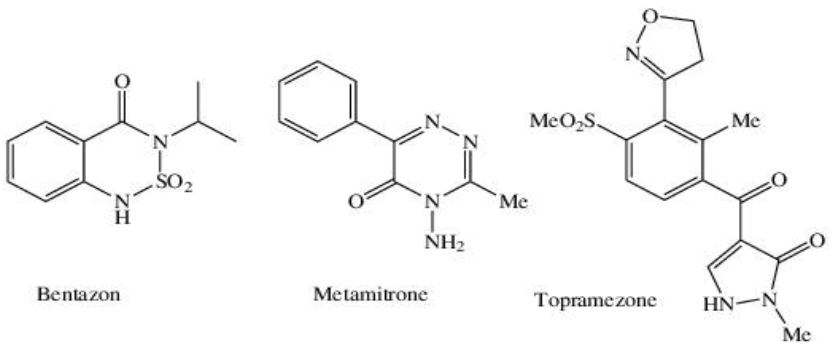

Figure 19: Structures of some of the herbicide agents whose metabolism is shown by studies with 1-ABT to involve cytochrome P450 enzymes.

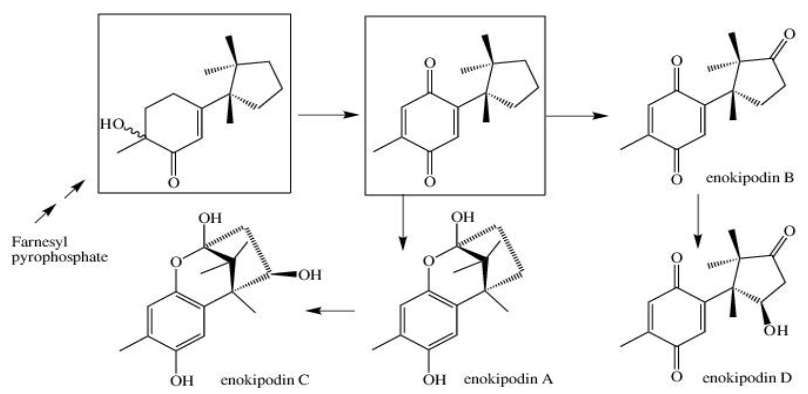

Figure 20: Two intermediates in the biosynthesis of enokipodin A, B, C, and $D$ identified as a result of inhibition of P450 enzymes by 1-ABT. The two intermediates are shown in the boxes. 
erythropolis [342], and the degradation of polychlorinated biphenyl by Ceriporia sp. ZLY-2010 [343].

\section{Conclusion}

$1-\mathrm{ABT}$ is an easily administered, mechanism-based inhibitor of most of the drug metabolizing isoforms of the cytochrome P450 family of enzymes, albeit with somewhat different sensitivities for the individual isoforms. Toxicity studies indicate that it is a relatively benign agent, even though in vivo it may interfere with sterol biosynthesis. It has been utilized in studies of mammals, insects, fish, and plants, using microsomal assays, intact cells, and in vivo. It has proven to be highly useful in situations where a pan-specific agent is required to inhibit the broad range of drug-metabolizing isoforms of cytochrome P450.

\section{Acknowledgments}

The preparation of this review was supported by National Institutes of Health grants GM25515 and Al074824.

\section{Disclosure Statement}

The author reports no conflicts of interest

\section{References}

1. Omura T (1999) Forty years of cytochrome P450. Biochem Biophys Res Commun 266: 690-698

2. Franklin MR, Hathaway LB (2008) 2-Diethylaminoethyl-2,2-diphenylvalerate$\mathrm{HCl}$ (SKF-525A) revisited: comparative cytochrome P450 inhibition in human liver microsomes by SKR525A, its metabolites, and SKF-acid and SKF-alcohol. Drug Metab Dispos 36: 2539-2546.

3. Rossi M (1983) Structural studies of metyrapone: A potent inhibitor of cytochrome P-450. J Med Chem 26: 1246-1252.

4. Guengerich FP (2009) Inhibition of drug metabolizing enzymes. Handbook of Drug Metabolism, $2^{\text {nd }}$ Ed. In: Pearson PG, Wienkers LC (eds.) pp: 203-226.

5. Correia MA, Hollenberg PF (2015) Inhibition of cytochrome P450 enzymes. Cytochrome P450: Structure, Mechanism, and Biochemistry, $4^{\text {th }}$ Ed. In: Ortiz de Montellano PR (ed.) pp: 177-259.

6. Emoto C, Murase S, Sawada Y, Jones BC, Iwasaki K (2003) In vitro inhibitory effect of 1-aminobenzotriazole on drug oxidations catalyzed by human cytochrome P450 enzymes: a comparison with SKF-525A and ketoconazole. Drug Metab Pharmacokin 18: 287-295.

7. Emoto C, Murase S, Sawada Y, Iwasaki K (2005) In vitro inhibitory effect of 1-aminobenzotriazole on drug oxidations in human liver microsomes: a comparison with SKF-525A. Drug Metab Pharmacokin 20: 351-357.

8. Luo Y, Yang X, Shi Q (2016) The cytochrome P450 inhibitor SKF-525A disrupts autophagy in primary rat hepatocytes. Chem Biol Interact 255: 55-62.

9. Bruce JIE, Elliott AC (2000) Pharmacological evaluation of the role of cytochrome $\mathrm{P} 450$ in intracellular calcium signaling in rat pancreatic acinar cells. Br J Pharmacol 131: 761-771

10. Kalgutkar AS, Obach RS, Maurer TS (2007) Mechanism-based inactivation of cytochrome P450 enzymes: chemical mechanisms, structure-activity relationships and relationship to clinical drug-drug interactions and idiosyncratic adverse drug reactions. Curr Drug Metab 8: 407-447.

11. Liu J, Sridhar J, Foroozesh M (2013) Cytochrome P450 family 1 inhibitors and structure-activity relationships. Molecules 18: 14470-14495.

12. Trave R, Bianchetti G (1960) Atti Accad Naz Lincei, Rend Classe Sci fis mat Nat 28: 652 .

13. Campbell CD, Rees CW (1969) Reactive intermediates. Part I. Synthesis and oxidation of 1- and 2-aminobenzotriazole. J Chem Soc pp: 742-747.

14. Campbell CD, Rees CW (1964) A new synthesis of benzyne. Proc Chem Soc London 296.

15. Campbell CD, Rees CW (1969) Reactive intermediates. Part III. Oxidation of 1-aminobenzotriazole with oxidants other than lead tetra-acetate. J Chem Soc pp: 752-756.

16. Ortiz de Montellano PR, Mathews JM (1981) Autocatalytic alkylation of the cytochrome P-450 prosthetic heme by 1 -aminobenzotriazole. Biochem J 195:
761-764.

17. Mathews JM, Dostal LA, Bend JR (1985) Inactivation of rabbit pulmonary cytochrome P450 in microsomes and isolated perfused lungs by the suicide substrate 1-aminobenzotriazole. J Pharmacol Exp Therap 235: 186-190.

18. Oldfield NF, Mortillo M, Garland WA, Mico BA (1992) Inhibition of hepatic and cutaneous biotransformation of resorufin ethers following intraperitoneal administration of 1-aminobenzotriazole. Pharmaceut Res 9: 1099-1102.

19. Carlile DJ, Hakooz N, Houston JB (1999) Kinetics of drug metabolism in rat liver slices: IV. Comparison of ethoxycoumarin clearance by liver slices, isolated hepatocytes, and hepatic microsomes from rats pretreated with known modifiers of cytochrome P-450 activity. Drug Metab Dispos 27: 526-532.

20. Ortiz de Montellano PR, Mathews JM, Langry KC (1984) Autocatalytic inactivation of cytochrome P-450 and chloroperoxidase by 1 -aminobenzotriazole and other aryne precursors. Tetrahedron 40: 511-519.

21. Chuanprasit $P$, Goh SH, Hirao H (2015) Benzyne formation in the mechanismbased inactivation of cytochrome $\mathrm{P} 450$ by 1 -aminobenzotriazole and $\mathrm{N}$-benzyl1-aminobenzotriazole: computational insights. ACS Catalysis 5: 2952-2960.

22. Mathews JM, Bend JR (1986) N-Alkylaminobenzotriazoles as isozymeselective suicide inhibitors of rabbit pulmonary microsomal cytochrome P450. Molec Pharmacol 30: 25-32.

23. Town C, Henderson L, Chang D, Mortillo M, Garland W (1993) Distribution of 1-aminobenzotriazole in male rats after administration of an oral dose. Xenobiotica 23: 383-390.

24. Sun Q, Harper TW, Dierks EA, Zhang L, Chang S, et al. (2011) 1-Aminobenzotriazole, a known cytochrome P450 inhibitor, is a substrate and inhibitor of N-acetyltransferase. Drug Metab Dispos 39: 1674-1679.

25. Mugford CA, Mortillo M, Mico BA, Tarloff JB (1992) 1-Aminobenzotriazoleinduced destruction of hepatic and renal cytochromes P450 in male SpragueDawley rats. Fund Appl Toxicol 19: 43-49.

26. Woodcroft KJ, Webb CD, Yao M, Weedon AC, Bend JR (1997) Metabolism of the cytochrome P450 mechanism-based inhibitor N-benzyl-1-aminobenzotriazole to products that covalently bind with protein in guinea pig liver and lung microsomes: comparative study with 1-aminobenzotriazole. Chem Res Toxicol 10: $589-599$.

27. Strelevitz TJ, Foti RS, Fisher MB (2006) In vivo use of the P450 inactivator 1 -aminobenzotriazole in the rat: varied dosing route to elucidate gut and liver contributions to first-pass and systemic clearance. J Pharm Sci 95: 1334-1341.

28. Boily MO, Chauret N, Laterreur J, Leblond FA, Boudreau C, et al. (2015) In vitro and in vivo mechanistic studies toward understanding the role of 1 -aminobenzotriazole in rat drug-drug interactions. Drug Metab Dispos 43:1960-1965

29. Parrish KE, Mao J, Chen J, Jaochico A, Ly J, et al. (2016) In vitro and in vivo characterization of CYP inhibition by 1 -aminobenzotriazole in rats. Biopharm Drug Dispos 37: 200-211.

30. Stringer RA, Weber E, Tigani B, Lavan P, Medhurst S, et al. (2014) 1-Aminobenzotriazole modulates oral drug pharmacokinetics through cytochrome P450 inhibition and delay of gastric emptying in rats. Drug Metab Dispos 42:1117-1124.

31. Stringer RA, Ferreira S, Rose J, Ronseaux S (2016) Application of osmotic pumps for sustained release of 1-aminobenzotriazole and inhibition of cytochrome P450 enzymes in mice: model comparison with the hepatic P450 reductase null mouse. Drug Metab Dispos 44:1213-1216.

32. Balani SK, Zhu T, Yang TJ, Liu Z, He B, et al. (2002) Effective dosing regimen of 1-aminobenzotriazole for inhibition of antipyrine clearance in rats, dogs, and monkeys. Drug Metab Disp 30:1059-1062.

33. Balani SK, Li P, Nguyen J, Cardoza K, Zeng H, et al. (2004) Effective dosing regimen of 1-aminobenzotriazole for inhibition of antipyrine clearance in guinea pigs and mice using serial sampling. Drug Metab Dispos 32:1092-1095.

34. Watanabe A, Mayumi K, Nishimura K, Osaki H (2016) In vivo use of the CYP inhibitor 1-aminobenzotriazole to increase long-term exposure in mice. Biopharm Drug Disp 37: 373-378.

35. Soto M, Pham R, Almon V, Wagner M, Primack R, et al. (2014) Evaluation of matrix microsampling methods for therapeutic drug candidate quantification in discovery-stage rodent pharmacokinetic studies. Bioanalysis 6: 2135-2146.

36. Deshmukh SV, Durston J, Shomer NH (2008) Validation of the use of non- 
naive surgically catheterized rats for pharmacokinetics studies. J Am Assoc Lab Anim Sci 47: 41-45.

37. Ortiz de Montellano PR, Mico BA, Mathews JM, Kunze KL, Miwa GT, et al. (1981) Selective inactivation of cytochrome P-450 isozymes by suicide substrates. Arch Biochem Biophys 210: 717-728.

38. Wong SG, Lin EH, Marks GS (1999) Cytochrome CYP sources of $\mathrm{N}$-alkylprotoporphyrin IX after administration of porphyrinogenic xenobiotics to rats. Drug Metab Dispos 27: 960-965.

39. Knickle LC, Bend JR (1992) Dose-dependent, mechanism-based inactivation of cytochrome P450 monooxygenases in vivo by 1 -aminobenzotriazole in liver, lung, and kidney of untreated, phenobarbital-treated, and $\beta$-naphthoflavonetreated guinea pigs. Can J Physiol Pharmacol 70: 1610-1617.

40. Riddick DS, MacKie JE, Massey TE, Marks GS (1990) 3,5-Diethoxycarbonyl2,6-dimethyl-4-ethyl-1,4-dihydropyridine inactivates rat liver cytochrome $\mathrm{P}-450 \mathrm{c}$, but not its orthologue, rabbit lung form 6. Can J Physiol Pharmaco 68: $370-373$.

41. Linder CD, Renaud NA, Hutzler JM (2009) Is 1-aminobenzotriazole an appropriate in vitro tool as a nonspecific cytochrome P450 inactivator? Drug Metab Dispos 37: 10-13.

42. Sodhi JK, Ford KA, Mukadam S, Wong S, Hop CECA, et al. (2014) 1-Aminobenzotriazole coincubated with (S)-warfarin results in potent inactivation of CYP2C9. Drug Metab Dispos 42: 813-817.

43. Tierney DJ, Haas AL, Koop DR (1992) Degradation of cytochrome P4502E1: selective loss after labilization of the enzyme. Arch Biochem Biophys 293: 9-16.

44. Sumner SCJ, Fennell TR, Moore TA, Chanas B, Gonzalez F, et al. (1999) Role of cytochrome P450 2E1 in the metabolism of acrylamide and acrylonitrile in mice. Chem Res Toxicol 12: 1110-1116.

45. Ghanayem BI, Sanders JM, Chanas B, Burka LT, Gonzalez FJ (1999) Role of cytochrome P450 2E1 in methacrylonitrile metabolism and disposition. J Pharm Exp Therap 289: 1054-1059.

46. Jackson TE, Lilly PD, Recio L, Schlosser PM, Medinsky MA (2000) Inhibition of cytochrome P450 2E1 decreases, but does not eliminate, genotoxicity mediated by 1,3-butadiene. Toxicol Sci 55: 266-273.

47. Hoffler U, El-Masri HA, Ghanayem BI (2003) Cytochrome P450 2E1 is the principal enzyme responsible for urethane metabolism: comparative studies using CYP2E1-null and wild-type mice. J Pharmacol Exp Therap 305: 557-564.

48. Muzeeb S, Pasha MK, Basha SJS, Mullangi R, Srinivas NR (2005) Effect of 1-aminobenzotriazole on the in vitro metabolism and single dose pharmacokinetics of chlorzoxazone, a selective CYP2E1 substrate in Wistar rats. Xenobiotica 35: 825-838

49. Dierks EA, Zhang Z, Johnson EF, Ortiz de Montellano PR (1998) The catalytic site of cytochrome P4504A11 (CYP4A11) and its L131F mutant. J Biol Chem 273: 23055-23061.

50. Dierks EA, Davis SC, Ortiz de Montellano PR (1998) Glu-320 and Asp-323 are determinants of the CYP4A1 hydroxylation regiospecificity and resistance to inactivation by 1-aminobenzotriazole. Biochemistry 37: 1839-1847.

51. Colby HD, Purcell H, Kominami S, Takemori S, Kossor DC (1994) Adrena activation of carbon tetrachloride: role of microsomal P450 isozymes. Toxicology 94: 31-40

52. Xu D, Voigt JM, Mico BA, Kominami S, Takemori S, et al. (1994) Inhibition of adrenal cytochromes P450 by 1-aminobenzotriazole in vitro. Selectivity for xenobiotic metabolism. Biochem Pharmacol 48: 1421-1426.

53. Xu D, Voigt J, Mico B, Colby H (1995) Inhibition of adrenal steroid metabolism by administration of 1 -aminobenzotriazole to guinea pigs. J Steroid Biochem Molec Biol 54: 281-285.

54. Colby HD, Abbott B, Cachovic M, Debolt KM, Mico BA (1995) Inactivation of adrenal cytochromes $\mathrm{P} 450$ by 1 -aminobenzotriazole. Divergence of in vivo and in vitro actions. Biochem Pharmacol 49: 1057-1062.

55. Soltis M, Colby H (1997) Inhibition of testicular steroid metabolism by administration of 1-aminobenzotriazole to rats. Pharmacol 56: 51-56.

56. Shaik AN, LeDuc BW, Khan AL (2017) Characterization of 1-aminobenzotriazole and ketoconazole as novel inhibitors of monoamine oxidase (MAO): an in vitro investigation. Eur J Drug Metab Pharmacokinet 42: 827-834.

57. di Re J, Lee C, Riddick DS (1999) Lack of mechanism-based inactivation of rat hepatic microsomal cytochromes P450 by doxorubicin. Can J Physiol
Pharmacol 77: 589-597.

58. Reichhart D, Simon A, Durst F, Mathews JM, Ortiz de Montellano PR (1982) Autocatalytic inactivation of plant cytochrome P-450 enzymes: Selective inactivation of cinnamic acid 4-hydroxylase from Helianthus tuberosus by 1-aminobenzotriazole. Arch Biochem Biophys 216: 522-529.

59. Mössner LD, Schmitz A, Theurillat R, Thormann W, Mevissen M (2011) Inhibition of cytochrome P450 enzymes involved in ketamine metabolism by use of liver microsomes and specific cytochrome P450 enzymes from horses, dogs, and humans. Am J Vet Res 72: 1505-1513.

60. Cashman JR (1986) A convenient assay for the flavin-containing monooxygenase. Analyt Biochem 160: 294-300.

61. Furnes B, Schlenk D (2005) Extrahepatic metabolism of carbamate and organophosphate thioether compounds by the flavin-containing monooxygenase and cytochrome P450 systems. Drug Metab Dispos 33: 214 218.

62. Cashman JR, Williams DE (1990) Enantioselective S-oxygenation of 2-aryl-1,3dithiolanes by rabbit lung enzyme preparations. Molec Pharmacol 37: 333-339.

63. Rettie AE, Bogucki BD, Lim I, Meier GP (1990) Stereoselective sulfoxidation of a series of alkyl p-tolylsulfides by microsomal and purified flavin-containing monooxygenases. Molec Pharmacol 37: 643-651.

64. Decker CJ, Doerge DR (1992) Covalent binding of ${ }^{14} \mathrm{C}$ - and ${ }^{35} \mathrm{~S}$-labeled thiocarbamides in rat hepatic microsomes. Biochem Pharmacol 43: 881-888.

65. Decker CJ, Doerge DR, Cashman JR (1992) Metabolism of benzimidazoline2-thiones by rat hepatic microsomes and hog liver flavin-containing monooxygenase. Chem Res Toxicol 5: 726-733.

66. Yang Y, Qiu F, Josephs JL, Humphreys WG, Xhu YZ (2012) Bioactivation of 2-(alkylthio)-1,3,4-thiadiazoles and 2-(alkylthio)-1,3-benzothiazoles. Chem Res Toxicol 25: 2770-2779.

67. Eng H, Sharma R, Wolfrd A, Di L, Ruggeri RB, et al. (2016) Species differences in the oxidative desulfurization of a thiouracil-based irreversible myeloperoxidase inactivator by flavin-containing monoxygenase enzymes. Drug Metab Dispos 44:1262-1269.

68. Martinkova M, Kubickova B, Stiborova M (2012) Effects of cytochrome P450 inhibitors on peroxidase activity. Neuro Endocrinol Lett 33: 33-40.

69. Kim PM, DeBoni U, Wells PG (1997) Peroxidase-dependent bioactivation and oxidation of DNA and protein in benzo[a]pyrene-initiated micronucleus formation. Free Rad Biol Med 23: 579-596.

70. Bedard LL, Smith GBJ, Reid KR, Petsikas D, Massey TE (2002) Investigations of the role of lipoxygenase in bioactivation of 4-(methylnitrosamino)-1-(3pyridyl)-1-butanone (NNK) in human lung. Chem Res Toxicol 15: 1267-1273.

71. Kimoto E, Walsky R, Zhang H, Bi Y, Whalen KM, et al. (2012) Differential modulation of cytochrome P450 activity and the effect of a-aminobenzotriazole on hepatic transport in sandwich-cultured human hepatocytes. Drug Metab Dispos 40: 407-411.

72. Crouch RD, Morrison RD, Byers FW, Lindsley CW, Emmitte KA, et al. (2016) Evaluating the disposition of a mixed aldehyde oxidase/cytochrome P450 substrate in rats with attenuated P450 activity. Drug Metab Dispos 44:12961303.

73. Yu L, Jiang Y, Wang L, Sheng R, Hu Y, et al. (2013) Metabolism of BYZX in human liver microsomes and cytosol: identification of the metabolites and metabolic pathways of BYZX. PLOS One 8: e59882.

74. Walsky RL, Bauman JN, Bourcier K, Giddens G, Lapham K, et al. (2012) Optimized assays for human UDP-glucuronosyltransferase (UGT) activities: altered alamethicin concentration and utility to screen for UGT inhibitors. Drug Metab Dispos 40:1051-1065.

75. Horng $\mathrm{H}$, Benet LZ (2013) The effects of 1-aminobenzotriazole inhibition on the formation of acyl-glucuronide and acyl-glutathione metabolites in rat hepatocytes. J Diagn Tech Biomed Anal 2:1

76. Plise EG, Halladay JS, Cheong J, Sodhi J, Salphati L (2010) Commonly used inhibitors of drug metabolizing enzymes: do they also inhibit drug transporters? Drug Metab Rev 42S: P190.

77. Fan PW, Chen JZ, Jaochico MA, La H, Liu N, et al. (2016) Rate-determining and rate-limiting steps in the clearance and excretion of a potent and selective p21-activated kinase inhibitor: A case study of rapid hepatic uptake and slow elimination in rat. Drug Metab Lett 10: 91-100. 
78. Kostrubsky SE, Strom SC, Kalgutkar AS, Kulkarni S, Atherton J, et al. (2006) Inhibition of hepatobiliary transport as a predictive method for clinical hepatotoxicity of nefazodone. Toxicol Sci 90: 451-459.

79. Ogimura E, Sekine S, Horie T (2011) Bile salt export pump inhibitors are associated with bile acid-dependent drug-induced toxicity in sandwich-cultured hepatocytes. Biochem Biophys Res Commun 416: 313-317.

80. Ortiz de Montellano PR, Costa AK (1986) Dissociation of cytochrome P-450 inactivation and induction. Arch Biochem Biophys 251: 514-524.

81. Yang $\mathrm{K}$, Koh $\mathrm{KH}$, Jeong $\mathrm{H}$ (2010) Induction of CYP2B6 and CYP3A4 expression by 1 -aminobenzotriazole (ABT) in human hepatocytes. Drug Metab Lett 4: 129133.

82. Zangar RC, Novak RF (1997) Effects of fatty acids and ketone bodies on cytochromes $\mathrm{P} 4502 \mathrm{~B}, 4 \mathrm{~A}$, and $2 \mathrm{E} 1$ expression in primary cultured rat hepatocytes. Arch Biochem Biophys 337: 217-224.

83. Feyereisen R, Langry KC, Ortiz de Montellano PR (1984) Self-catalyzed destruction of insect cytochrome P-450. Insect Biochem 14:19-26.

84. Gaillardon P, Cabanne F, Scalla R, Durst F (1985) Effect of mixed function oxidase inhibitors on the toxicity of chlortoluron and isoproturon to wheat. Weed Res 25: 397-402

85. Mico BA, Federowicz DA, Ripple MG, Kerns W (1988) In vivo inhibition of oxidative drug metabolism by, and acute toxicity of, 1-aminobenzotriazole (ABT). A tool for biochemical toxicology. Biochem Pharmacol 37: 2515-2519.

86. Isayama F, Froh M, Bradford BU, McKim SE, Kadiiska MB, et al. (2003) The CYP inhibitor 1-aminobenzotriazole does not prevent oxidative stress associated with alcohol-induced liver injury in rats and mice. Free Rad Bio Med 35: 1568-1581.

87. Meschter CL, Mico BA, Mortillo M, Feldman D, Garland WA, et al. (1994) A 13-week toxicologic and pathologic evaluation of prolonged cytochromes P450 inhibition by 1-aminobenzotriazole in male rats. Fundam Appl Toxicol 22: 369381

88. Moorthy B, Parker KM, Smith CV, Bend JR, Welty SE (2000) Potentiation of oxygen-induced lung injury in rats by the mechanism-based cytochrome P-450 inhibitor, 1-aminobenzotriazole. J Pharmacol Exp Therap 292: 553-560.

89. Woodcroft KJ, Szczepan EW, Knickle LC, Bend JR (1990) Three N-aralkylated derivatives of 1-aminobenzotriazole as potent and isozyme selective, mechanism-based inhibitors of guinea pig pulmonary cytochrome $\mathrm{P} 450$ in vitro. Drug Metab Disp 18: 1031-1037.

90. Sinal CJ, Bend JR (1995) Isozyme-selective metabolic intermediate complex formation of guinea pig hepatic cytochrome $\mathrm{P} 450$ by $\mathrm{N}$-aralkylated derivatives of 1-aminobenzotriazole. Chem Res Toxicol 8: 82-91

91. Sinal C, Bend J (1996) Kinetics and selectivity of mechanism-based inhibition of guinea pig hepatic and pulmonary cytochrome $\mathrm{P} 450$ by $\mathrm{N}$-benzyl-1aminobenzotriazole and N- $\searrow$-methylbenzyl-1-aminobenzotriazole. Drug Metab Disp 24: 996-1001.

92. Kent U, Hanna I, Szklarz G, Vaz A, Halpert J, et al. (1997) Significance of glycine 478 in the metabolism of $\mathrm{N}$-benzyl-1-aminobenzotriazole to reactive intermediates by cytochrome P450 2B1. Biochemistry 36:11707-11716.

93. Kent UM, Pascual L, Roof RA, Ballou DP, Hollenberg PF (2004) Mechanistic studies with N-benzyl-1-aminobenzotriazole-inactivated CYP2B1: differential effects on the metabolism of 7-ethoxy-4-(trifluoromethyl)coumarin testosterone, and benzphetamine. Arch Biochem Biophys 423: 277-287.

94. McCallum GP, Horton JE, Flakner KC, Bend JR (1993) Microsomal cytochrome P450 1A1 dependent monooxygenase activity in guinea pig heart: induction, inhibition, and increased activity by addition of exogenous NADPH-cytochrome P450 reductase. Can J Physiol Pharmacol 71: 151-156.

95. Sinal C, Hirst M, Webb C, Bend J (1998) Enantioselective, mechanism-based inactivation of guinea pig hepatic cytochrome $\mathrm{P} 450$ by N-(a-methylbenzyl)-1aminobenzotriazole. Drug Metab Disp 26: 681-688.

96. Knickle LC, Philpot RM, Bend JR (1994) N-aralkylated derivatives of 1-aminobenzotriazole are potent isozyme- and lung-selective mechanismbased inhibitors of guinea pig cytochrome P450 in vivo. J Pharmacol Exp Therap 270: 377-385

97. WoodcroftKJ, Bend JR (1990) N-Aralkylated derivatives of 1-aminobenzotriazole as isozyme-selective, mechanism-based inhibitors of guinea pig hepatic cytochrome P-450 dependent monooxygenase activity. Can J Physiol Pharmacol 68: 1278-1285.
98. Mathews JM, Bend JR (1993) N-Aralkyl derivatives of 1-aminobenzotriazole as potent isozyme and tissue selective mechanism-based inhibitors of rabbit pulmonary cytochrome P450 in vivo. J Pharmacol Exp Therap 265: 281-285.

99. Grimm SW, Bend JR, Halpert JR (1995) Selectivity and kinetics of inactivation of rabbit hepatic cytochromes $\mathrm{P} 4502 \mathrm{~B} 4$ and $2 \mathrm{~B} 5$ by $\mathrm{N}$-aralkylated derivatives of 1-aminobenzotriazole. Drug Metab Disp 23: 577-583.

100. Knickle LC, Webb CD, House AA, Bend JR (1993) Mechanism-based inactivation of cytochrome P450 $1 \mathrm{~A} 1$ by $\mathrm{N}$-aralkyl-1-aminobenzotriazoles in guinea pig kidney in vivo and in vitro: minimal effects on metabolism of arachidonic acid by renal P450-dependent monooxygenases. J Pharmacol Exp Therap 267: 758-764.

101. Knickle LC, Bend JR (1994) Bioactivation of arachidonic acid by the cytochrome P450 monooxygenases of guinea pig lung: the orthologue of cytochrome P450 2B4 is solely responsible for formation of epoxyeicosatrienoic acid. Molec Pharmacol 45:1273-1280.

102. Lu P, Singh SB, Carr BA, Fang Y, Xiang CD, et al. (2005) Selective inhibition of dog hepatic CYP2B11 and CYP3A12. J Pharmacol Exp Therap 313: 518528 .

103. Hahn V, Mikolasch A, Wende K, Bartrow H, Lindequist $U$, et al. (2010) Derivatization of the azole 1-aminobenzotriazole using laccase of Pycnoporus cinnabarinus and Myceliophthora thermophila: influence of methanol on the reaction and biological evaluation of the derivatives. Biotechnol Appl Biochem 56: 43-48.

104. Caldwell GW, Ritchie DM, Masucci JA, Hageman W, Cotto C, et al. (2005) The use of the suicide CYP450 inhibitor ABT for distinguishing absorption and metabolism processes in in-vivo pharmacokinetic screens. Eur J Drug Metab Pharmacokinet 30: 75-83.

105. El-Kattan AF, Poe J, Buchholz L, Thomas HV, Brodfuehrer J, et al. (2008) The use of 1-aminobenzotriazole in differentiating the role of CYP-mediated first pass metabolism and absorption in limiting drug oral bioavailability: a case study. Drug Metab Lett 2: 120-124.

106. Anby MU, Nguyen TH, Yeap YY, Feeney OM, Williams HD, et al. (2014) An in vitro digestion test that reflects rat intestinal conditions to probe the importance of formulation digestion vs first pass metabolism in danazo bioavailability from lipid based formulations. Mol Pharmaceut 11: 4069-4083.

107. Saitta KS, Zhang C, Lee KK, Fujimoto K, Redinbo MR, et al. (2014) Bacterial b-glucuronidase inhibition protects mice against enteropathy induced by indomethacin, ketoprofen or diclofenac: mode of action and pharmacokinetics. Xenobiotica 44:28-35.

108. Takahashi M, Washio T, Suzuki N, Igeta K, Yamashita S (2010) Investigation of the intestinal permeability and first-pass metabolism of drugs in cynomolgus monkeys using single-pass intestinal perfusion. Biol Pharm Bull 33: 111-116.

109. Grimsley A, Foster A, Gallagher R, Hutchinson M, Lundqvist A, et al. (2014) A comparison of the metabolism of midazolam in C57BL/6J and hepatic reductase null (HRN) mice. Biochem Pharmacol 92: 701-711.

110. Bylund J, Bueters T (2013) Presystemic metabolism of AZ'0908, a nove mPGES-1 inhibitor: an in vitro and in vivo cross-species comparison. J Pharm Sci 102: 1106-1115.

111. Watanabe A, Watari R, Ogawa K, Shimizu R, Tanaka Y, et al. (2015) Using improved serial blood sampling method of mice to study pharmacokinetics and drug-drug interactions. J Pharmaceut Sci 104: 955-961.

112. Ballard $\mathrm{P}$, Barlaam BC, Bradbury RH, Dishington A, Hennequin LFA, et al (2007) Neutral 5-substituted 4-anilinoquinazolines as potent, orally active inhibitors of erbB2 receptor tyrosine kinase. Bioorg Med Chem Lett 17: 63266329.

113. Li AP, Doshi U (2011) Higher throughput human hepatocyte assays for the evaluation of time-dependent inhibition of CYP3A4. Drug Metab Lett, 5: 183191.

114. Li AP (2009) Evaluation of luciferin-isopropyl acetal as a CYP3A4 substrate for human hepatocytes: effects of organic solvents, cytochrome P450 (P450) inhibitors, and P450 inducers. Drug Metab Dispos 37: 1598-1603.

115. Doshi U, Li AP (2011) Luciferin IPA-based higher throughput human hepatocytes screening assays for CYP3A4 inhibition and induction. J Biomol Screen 16: 903-909.

116. Feng PCC, Solsten RT (1994) In vitro biotransformation of thiazopyr by rat liver microsomes: oxidative cleavage of a carboxylic methylester by monooxygenases. Xenobiotica 24: 729-734. 
117. Eng H, Niosi M, McDonald TS, Wolford A, Chen Y, et al. (2010) Utility of the carboxylesterase inhibitor bis-para-nitrophenylphosphate (BNPP) in the plasma unbound fraction determination for a hydrolytically unstable amide derivative and agonist of the TGR5 receptor. Xenobiotica 40: 369-380.

118. Takahashi R, Ma S, Deese A, Yue Q, Kim-Kang H, et al. (2014) Elucidating the mechanism of cytochrome P450-mediated pyrimidine ring conversion to pyrazole metabolites with the BACE1 inhibitor GNE-892 in rats. Drug Metab Dispos 42: 890-898.

119. Jones BC, Markandu R, Gu C, Scarfe G (2017) CYP-mediated sulfoximine deamination of AZD6738. Drug Metab Dispos 45: 1133-1138.

120. Gu Y, Guise CP, Patel K, Abbattista MR, Li J, et al. (2011) Reductive metabolism of the dinitrobenzamide mustard anticancer prodrug PR-104 in mice. Cancer Chemother Pharmacol 67: 543-555.

121. Gombar CT, Burak E, Harper N, Smith BR (1988) Pulmonary clearance of vasoactive drugs: $\mathrm{N}$-oxidation of SK\&F 86466 in the isolated perfused rat lung. J Pharmacol Exp Therap 245: 402-406.

122. Wang $Z$, Fang $Y$, Teague $J$, Wong $H$, Morisseau $C$, et al. (2017) In vitro metabolism of oprozomib, an oral proteasome inhibitor: Role of epoxide hydrolases and cytochrome P450. Drug Metab Dispos 45: 712-720.

123. Capello S, Henderson L, DeGrazia F, Liberato D, Garland W, et al. (1990) The effect of the cytochrome P450 suicide inactivator, 1-aminobenzotriazole, on the in vivo metabolism and pharmacologic activity of flurazepam. Drug Metab Disp 18: 190-196.

124. Lake BG, Price RJ, Walters DG, Phillips JC, Young PJ, et al. (2003) Studies on the metabolism of the thiofurans furfuryl mercaptan and 2-methyl-3furanthiol in rat liver. Food Chem Toxicol 41: 1761-1770.

125. Sanderson JP, Hollis FJ, Maggs JL, Clarke SE, Naisbitt DJ, et al. (2008) Nonenzymatic formation of a novel hydroxylated sulfamethoxazole derivative in human liver microsomes: implications for bioanalysis of sulfamethoxazole metabolites. Drug Metab Dispos 36: 2424-2428.

126. Charman SA, Arbe-Barnes S, Bathurst IC, Brun R, Campbell M, et al. (2011) Synthetic ozonide drug candidate OZ439 offers new hope for a single-dose cure of uncomplicated malaria. Proc Natl Acad Sci USA 108: 4400-4405.

127. Mishra S, Manickavasagam L, Jain GK (2012) Determination of metabolic profile of anti-malarial trioxane CDRI 99/411 in rat liver microsomes using HPLC. Biomed Chromatogr 26: 115-122.

128. Chen H, Soroka D, Zhu Y, Sang S (2013) Metabolism of ginger component [6]-shogaol in liver microsomes from mouse, rat, dog, monkey, and human. Mol Nutr Food Res 57: 865-876.

129. Yue Q, Mulder T, Rudewicz PJ, Solon E, Budha N, et al. (2013) Evaluation of metabolism and disposition of GDC-0152 in rats using ${ }^{14} \mathrm{C}$-labeling strategy at two different positions: a novel formation of hippuric acid from 4-phenyl-5amino-1,2,3-thiadiazole. Drug Metab Dispos 41: 508-517.

130. Ning J, Yu ZL, Hu LH, Wang C, Huo XK, et al. (2015) Characterization of phase I metabolism of resibufogenin and evaluation of the metabolic effects on its antitumor activity and toxicity. Drug Metab Dispos 43: 299-308.

131. Guo J, Joubran C, Luzietti RA, Basarab GS, Grimm SW, et al. (2017) Absorption, distribution, metabolism and elimination of ${ }^{14} \mathrm{C}-\mathrm{ETX} 0914$, a novel inhibitor of bacterial type-II topoisomerases in rodents. Xenobiotica 47: 3149.

132. Zhang J, Li L, Tang S, Hale TW, Xing C, et al. (2015) Cytochrome P450 isoforms in the metabolism of decursin and decursinol angelate from Koean angelica. Am J Chin Med 43: 1211-1230.

133. Klieber S, Arabeyre-Fabre C, Moliner P, Marti E, Mandray M, et al. (2014) Identification of metabolic pathways and enzyme systems involved in the in vitro human hepatic metabolism of dronedarone, a potent new oral antiarrhythmic drug. Pharmacol Res Perspect 2: e00044.

134. Dalmadi B, Leibinger J, Szeberényi S, Borbás T, Farkas S, et al. (2003) Identification of metabolic pathways involved in the biotransformation of tolperisone by human microsomal enzymes. Drug Metab Dispos 31: 631636

135. Wang MZ, Saulter JY, Usuki E, Cheung YL, Hall M, et al. (2006) CYP4F enzymes are the major enzymes in human liver microsomes that catalyze the O-demethylation of the antiparasitic prodrug DB289 [2,5-bis(4-amidinophenyl) furan-bis-O-methylamidoxime. Drug Metab Dispos 34: 1985-1994.

136. Stevens GJ, Hitchcock K, Wang YK, Coppola GM, Versace RW, et al. (1997)
In vitro metabolism of $\mathrm{N}$-(5-chloro-2-methylphenyl)-N'-(2-methylpropyl) thiourea: species comparison and identification of a novel thiocarbamideglutathione adduct. Chem Res Toxicol 10: 733-741.

137. Boer J, Young-Sciame R, Lee F, Bowman KJ, Yang X, et al. (2016) The role of UGT, CYP and gut microbiota in the metabolism of epacadostat (EPA) in humans. Drug Metab Dispos 44: 1668-1674.

138. Leong BK, Sabaitis CP, Rop DA, Jeffrey P, Parker TJ, et al. (1997) Alterations in the cardiopulmonary effects and pharmacokinetics of a bisphosphonate drug by a cytochrome P-450 inhibitor in conscious rats. J Appl Toxicol 17 279-288.

139. Tang W, Stearns RA, Chen Q, Bleasby K, Teffera Y, et al. (2008) Importance of mechanistic drug metabolism studies in support of drug discovery: A case study with an N-sulfonylated dipeptide VLA-4 antagonist in rats. Xenobiotica 38: 223-237

140. Kenneke JF, Mazur CS, Ritger SE, Sack TJ (2008) Mechanistic investigation of the noncytochrome P450-mediated metabolism of triadimefon to triadimenol in hepatic microsomes. Chem Res Toxicol 21: 1997-2004.

141. Wityak J, McGee KF, Conlon MP, Song RH, Duffy BC, et al. (2015) Lead optimization towards proof-of-concept tools for Huntington's disease within a 4-(1H-pyrazol-4-yl)pyrimidine class of pan-JNK inhibitors. J Med Chem 58: 2967-2987.

142. Kurata H, Gentry PR, Kokubo M, Cho HP, Bridges TM, et al. (2015) Further optimization of the M5 NAM MLPCN probe ML375: tactics and challenges. Bioorg Med Chem Lett 25: 690-694.

143. Kaul M, Mark L, Zhang Y, Parhi AK, Lyu YL, et al. (2015) TXA709, an FtsZ targeting benzamide prodrug with improved pharmacokinetics and enhanced in vivo efficacy against methicillin-resistant Staphylococcus aureus. Antimicrob Agents Chemother 59: 4845-4855.

144. Reich NO, Ortiz de Montellano PR (1986) Dissociation of increased lauric acid omega-hydroxylase activity from the antilipidemic action of clofibrate. Biochem Pharmacol 35: 1227-1233.

145. Romano MC, Straub KM, Yodis LAP, Eckhardt RD, Newton JF (1988) Determination of microsomal lauric acid hydroxylase activity by HPLC with flow-through radiochemical quantitation. Anal Biochem 170: 83-93.

146. Ortiz de Montellano PR, Reich NO (1984) Specific inactivation of hepatic fatty acid hydroxylases by acetylenic fatty acids. J Biol Chem 259: 4136-4141.

147. Kaikaus RM, Chan WK, Lysenko N, Ray R, Ortiz de Montellano PR, et al. (1993) Induction of peroxisomal fatty acid b-oxidation and liver fatty acidbinding protein by peroxisome proliferators. Mediation via the cytochrome P-450IVA1 w-hydroxylase pathway. J Biol Chem 268: 9593-9603.

148. Su P, Kaushal KM, Kroetz DL (1998) Inhibition of renal arachidonic acid w-hydroxylase activity with ABT reduces blood pressure in the SHR. Am J Physiol 275: R426-R438.

149. Maier KG, Henderson L, Narayanan J, Alonso-Galicia M, Falck JR, et al (2000) Fluorescent HPLC assay for 20-HETE and other P-450 metabolites of arachidonic acid. Am. J Physiol Heart Circ Physiol 279: H863-H871.

150. Hoagland KM, Flasch AK, Roman RJ (2003) Inhibitors of 20-HETE formation promote salt-sensitive hypertension in rats. Hypertension 42: 669-673.

151. Dos Santos EA, Dahly-Vernon AJ, Hoagland KM, Roman RJ (2004) Inhibition of the formation of EETs and 20-HETE with 1-aminobenzotriazole attenuates pressure natriuresis. Am J Physiol Regul Integr Comp Physiol 287: R58-R68.

152. Sarkis A, Ito O, Mori T, Kohzuki M, Ito S, et al. (2005) Cytochrome P450dependent metabolism of arachidonic acid in the kidney of rats with diabetes insipidus. Am J Physiol Renal Physiol 289: F1333-F1340.

153. Coceani F, Kelsey L, Seidlitz E, Korzekwa K (1996) Inhibition of the contraction of the ductus arteriosus to oxygen by 1-aminobenzotriazole, a mechanism-based inactivator of cytochrome P450. Brit J Pharmacol 117: 1586-1592.

154. Pagliaro P, Penna C, Rastaldo R, Mancardi D, Crisafulli A, et al. (2004) Endothelial cytochrome P450 contributes to the acetylcholine-induced cardiodepression in isolated rat hearts. Acta Physiol Scand 182: 11-20.

155. Vanheel B, Van de Voorde J (1997) Evidence against the involvement of cytochrome P450 metabolites in endothelium-dependent hyperpolarization of the rat main mesenteric artery. J Physiol 501: 331-341.

156. Vanheel B, Calders P, Van den Bossche I, Van de Voorde J (1999) Influence 
of some phospholipase $A_{2}$ and cytochrome P450 inhibitors on rat arterial smooth muscle $\mathrm{K}^{+}$currents. Can J Physiol Pharmacol 77: 481-489.

157. Walkowska A, Kuczeriszka M, Sadowski J, Olszynski KH, Dobrowolski L, et al. (2015) High salt intake increases blood pressure in normal rats: putative role of 20 -HETE and no evidence on changes in renal vascular reactivity. Kidney Blood Press Res 40: 323-334.

158. Rastaldo R, Paolocci N, Chiribiri A, Penna C, Gattullo D, et al. (2001) Cytochrome P-450 metabolite of arachidonic acid mediates bradykinininduced negative inotropic effect. Am J Physiol Heart Circ Physiol 280: $\mathrm{H} 2823-\mathrm{H} 2832$.

159. Badzy'nska B, Sadowski J (2009) Differential action of bradykinin on intrarenal regional perfusion in the rat: waning effect in the cortex and major impact in the medulla. J Physiol (Lond) 587: 3943-3953.

160. Ceresa F, Delfino A, de Matteis A, Ferrero N, Novarino M, et al. (1999) The coronary vasculature and the myocardium. Boll Soc Ital Biol Sper 75: 1-8.

161. Blanton A, Nsaif R, Hercule H, Oyekan A (2006) Nitric oxide/cytochrome P450 interactions in cyclosporin A-induced effects in the rat. J Hypertens 24: $1865-1872$

162. López B, Moreno C, Salom MG, Roman RJ, Fenoy FJ (2001) Role of guanylyl cyclase and cytochrome P-450 on renal response to nitric oxide. Am J Physiol Renal Physiol 281: F420-F427.

163. Dobrowolski L, Walkowska A, Kompanowska-Jezierska E, Kuczeriszka M Sadowski J (2007) Effects of ATP on rat renal haemodynamics and excretion: role of sodium intake, nitric oxide and cytochrome P450. Acta Physiol (Oxf) 189: 77-85.

164. Tunctan B, Yaghini FA, Estes A, Malik KU (2006) Inhibition by nitric oxide of cytochrome P450 4A activity contributes to endotoxin-induced hypotension in rats. Nitric Oxide 14: 51-57.

165. Wang $\mathrm{MH}$, Wang J, Chang $\mathrm{HH}$, Zand BA, Jiang M, et al. (2003) Regulation of renal CYP4A expression and 20-HETE synthesis by nitric oxide in pregnant rats. Am J Physiol Renal Physiol 285: F295-F302.

166. He H, Podymow T, Zimpelmann J, Burns KD (2003) NO inhibits $\mathrm{Na}^{+}-\mathrm{K}^{+}-2 \mathrm{Cl}^{-}$ cotransport via a cytochrome P450-dependent pathway in renal epithelia cells (MMDD1). Am J Physiol Renal Physiol 284: F1235-F1244.

167. Benter IF, Francis I, Cojocel C, Juggi JS, Yousif MHM, et al. (2005) Contribution of cytochrome P450 metabolites of arachidonic acid to hypertension and end-organ damage in spontaneously hypertensive rats treated with L-NAME. Auton Autacoid Pharmacol 25: 143-154.

168. Hatton CJ, Peers C (1996) Effects of cytochrome P-450 inhibitors on ionic currents in isolated rat type I carotid body cells. Am J Physiol 271: C85-C92.

169. Hatton CJ, Peers C (1996) Is cytochrome P-450 involved in hypoxic inhibition of $\mathrm{K}^{+}$currents in rat type I carotid body cells? Adv Exp Med Biol 410: 89-92.

170. Hatton CJ, Peers C (1998) Arachidonic acid inhibits both $\mathrm{K}^{+}$and $\mathrm{Ca}^{2+}$ currents in isolated type I cells of the rat carotid body. Brain Res 787: 315-320.

171. Van der Voorde J, Vanheel B (1997) Influence of cytochrome P-450 inhibitors on endothelium-dependent nitro-L-arginine-resistant relaxation and cromakalim-induced relaxation in rat mesenteric arteries. J Cardiovas Pharmacol 29: 827-832.

172. Iftinca M, Waldron GJ, Triggle CR, Cole WC (2001) State-dependent block of rabbit vascular smooth muscle delayed rectifier and Kv1.5 channels by inhibitors of cytochrome P450-dependent enzymes. J Pharmacol Exp Ther 298: 718-728.

173. Yuan XJ, Tod ML, Rubin LJ, Blaustein MP (1995) Inhibition of cytochrome $\mathrm{P}-450$ reduces voltage-gated $\mathrm{K}^{+}$currents in pulmonary arterial myocytes. Am J Physiol 268: C259-C270.

174. Muthalif MM, Karzoun NA, Gaber L, Khandekar Z, Benter IF, et al. (2000) Angiotensin II-induced hypertension: contribution of Ras GTPase/mitogenactivated protein kinase and cytochrome P450 metabolites. Hypertension 36 604-609.

175. Alonso-Galicia M, Maier KG, Greene AS, Cowley AW, Roman RJ (2002) Role of 20-hydroxyeicosatetraenoic acid in the renal and vasoconstrictor actions of angiotensin II. Am J Physiol Regul Integr Comp Physiol 283: R60-R68.

176. Lima R, Yanes LL, Davis DD, Reckelhoff JF (2013) Roles played by 20HETE, angiotensin II and endothelin in mediating the hypertension in aging female spontaneously hypertensive rats. Am J Physiol Regul Integr Comp
Physiol 304: R248-R251.

177. Yousif MHM, Benter IF, Dunn KMJ, Dahly-Vernon AJ, Akhtar S, et al. (2009) Role of 20-hydroxyeicosatetraenoic acid in altering vascular reactivity in diabetes. Auton Autacoid Pharmacol 29: 1-12.

178. Yanes LL, Lima R, Moulana M, Romero DG, Yuan K, et al. (2011) Postmenopausal hypertension: role of 20-HETE. Am J Physiol Regul Integr Comp Physiol 300: R1543-1548.

179. Wang MH, Zand BA, Nasjletti A, Laniado-Schwartzman M (2002) Rena 20-hydroxyeicosatetraenoic acid synthesis during pregnancy. Am J Physio Regul Integr Comp Physiol 282: R383-R389.

180. Llinás MT, Alexander BT, Capparelli MF, Carroll MA, Granger JP (2004) Cytochrome P-450 inhibition attenuates hypertension induced by reductions in uterine perfusion pressure in pregnant rats. Hypertension 43: 623-628.

181. Benter IF, Yousif MHM, Canatan H, Akhtar S (2005) Inhibition of $\mathrm{Ca}^{2+} /$ calmodulin-dependent protein kinase II, RAS-GTPase and 20-hydroxyeicosatetraenoic acid attenuates the development of diabetesinduced vascular dysfunction in the rat carotid artery. Pharmacol Res 52 : 252-257.

182. Vasudevan H, Yuen VG, McNeill JH (2012) Testosterone-dependent increase in blood pressure is mediated by elevated Cyp4A expression in fructose-fed rats. Mol Cell Biochem 359: 409-418.

183. Williams JM, Sarkis A, Lopez B, Ryan RP, Flasch AK, et al. (2007) Elevations in renal interstitial hydrostatic pressure and 20-hydroxyeicosatetraenoic acid contribute to pressure natriuresis. Hypertension 49: 687-694.

184. Fernandez MMF, Gonzalez D, Williams JM, Roman RJ, Nowicki S (2012) Inhibitors of 20-hydroxyeicosatetraenoic acid (20-HETE) formation attenuate the natriuretic effect of dopamine. Eur J Pharmacol 686: 97-103.

185. Oyekan A, McAward K, Conetta J, Rosenfeld L, McGiff J (1999) Endothelin-1 and CYP450 arachidonate metabolites interact to promote tissue injury in DOCA-salt hypertension. Am J Physiol Regul Integr C 45: R766-R775.

186. Kuczeriszka M, Badzynska B, Kompanowska-Jezierska E (2006) Cytochrome P-450 monooxygenases in control of renal haemodynamics and arterial pressure in anaesthetized rats. J Physiol Pharmacol 57: 179-185.

187. Chábová CV, Kramer HJ, Vanecková I, Vernerová Z, Eis V, et al. (2007) Effects of chronic cytochrome P-450 inhibition on the course of hypertension and end-organ damage in Ren-2 transgenic rats. Vascul Pharmacol 47: 145159.

188. Kauser $\mathrm{K}$, Clark JE, Masters BS, Ortiz de Montellano PR, Ma YH, et at. (1991) Inhibitors of cytochrome P-450 attenuate the myogenic response of dog renal arcuate arteries. Circ Res 68: 1154-1163.

189. Orozco LD, Liu H, Perkins E, Johnson DA, Chen BB, et al. (2013) 20-Hydroxyeicosatetraenoic acid inhibition attenuates balloon injury-induced neointima formation and vascular remodeling in rat carotid arteries. Pharmacol Exp Ther 346: 67-74.

190. Amaral SL, Maier KG, Schippers DN, Roman RJ, Greene AS (2003) CYP4A metabolites of arachidonic acid and VEGF are mediators of skeletal muscle angiogenesis. Am J Physiol Heart Circ Physiol 284: H1528-H1535.

191. El Azher MA, Havet N, Singer M, Dumarey C, Touqui L (2000) Inhibition by unsaturated fatty acids of type II secretory phospholipase A2 synthesis in guinea-pig alveolar macrophages evidence for the eicosanoid-independent pathway. Eur J Biochem 267: 3633-3639.

192. Saxena NC (2000) Inhibition of GABA(A) receptor (GABAR) currents by arachidonic acid in HEK 293 cells stably transfected with alpha1 beta2gamma2 GABAR subunits. Pflugers Arch 440: 380-392.

193. Nieves D, Moreno JJ (2006) Hydroxyeicosatetraenoic acids released through the cytochrome P-450 pathway regulate 3T6 fibroblast growth. J Lipid Res 47: 2681-2689.

194. Feddersen CO, Chang S, Czartalomna J, Voelkel NF (1990) Arachidonic acid causes cyclooxygenase-dependent and -independent pulmonary vasodilation. J Appl Physiol 68: 1799-1808.

195. Chang SW, Dutton D, Wang HL, He LS, Stearns R, et al. (1992) Intact lung cytochrome $\mathrm{P}-450$ is not required for hypoxic pulmonary vasoconstriction. Am J Physiol 263: L446-L453.

196. Weissmann N, Seeger W, Conzen J, Kiss L, Grimminger F (1998) Effects of arachidonic acid metabolism on hypoxic vasoconstriction in rabbit lungs. Eur 
Citation: Ortiz de Montellano PR (2018) 1-Aminobenzotriazole: A Mechanism-Based Cytochrome P450 Inhibitor and Probe of Cytochrome P450 Biology. Med Chem (Los Angeles) 8: 038-065. doi: 10.4172/2161-0444.1000495

J Pharmacol 356: 231-237.

197. Cooper PR, Mesaros AC, Zhang J, Christmas P, Stark CM, et al. (2010) 20-HETE mediates ozone-induced, neutrophil-independent airway hyperresponsiveness in mice. PLoS ONE 5: e10235.

198. Dubey RK, Gillespie DG, Zacharia LC, Rosselli M, Imthurn B, et al. (2002) Methoxyestradiols mediate the antimitogenic effects of locally applied estradiol on cardiac fibroblast growth. Hypertension 39: 412-417.

199. Dubey RK, Gillespie DG, Keller PJ, Imthurn B, Zacharia LC, et al. (2002) Role of methoxyestradiols in the growth inhibitory effects of estradiol on human glomerular mesangial cells. Hypertension 39: 418-424.

200. Barchiesi F, Jackson EK, Gillespie DG, Zacharia LC, Fingerie J, et al. (2002) Methoxyestradiols mediate estradiol-induced antimitogenesis in human aortic SMCs. Hypertension 39: 874-879.

201. Dubey RK, Gillespie DG, Zacharia LC, Barchiesi F, Imthurn B, et al. (2003) CYP450- and COMT-derived estradiol metabolites inhibit activity of human coronary artery SMCs. Hypertension 41: 807-813.

202. Dubey RK, Jackson EK, Gillespie DG, Rosselli M, Barchiesi F, et al (2005) Cytochromes 1A1/1B1- and catechol-O-methyltransferase-derived metabolites mediate estradiol-induced antimitogenesis in human cardiac fibroblast. J Clin Endocrinol Metab 90: 247-255.

203. Zhang Z, Zhu C, Zhang X, Wan Y, Song J (2011) Dual effects of estrogen on vascular smooth muscle cells: receptor-mediated proliferative vs. metaboliteinduced pro-senescent actions. Steroids 76: 309-316.

204. Gui Y, Zheng XL, Zheng J, Walsh MP (2008) Inhibition of rat aortic smooth muscle contraction by 2-methoxyestradiol. Am J Physiol Heart Circ Physio 295: H1935-H1942.

205. Miyamoto H, Matsueda S, Moritsuka A, Shimokawa K, Hirata H, et al. (2015) Evaluation of hypothermia on the in vitro metabolism and binding and in vivo disposition of midazolam in rats. Biopharm Drug Dispos 36: 481-489.

206. Poole A, Jones RB, Pritchard D, Catto L, Leonard T (1989) In vitro accumulation of thyroid hormones by cultured rat hepatocytes and the biliary excretion of iodothyronines in rats treated with a novel histamine $\mathrm{H} 2$-receptor antagonist. Toxicology 59: 23-36.

207. Poole A, Pritchard D, Jones RB, Catto L, Leonard T (1990) In vivo biliary excretion and in vitro cellular accumulation of thyroxine by rats or cultured rat hepatocytes treated with a novel histamine H1-receptor antagonist. Arch Toxicol 64: 474-481.

208. Behne M, Uchida Y, Seki T, Ortiz de Montellano PR, Elias PM, et al. (2000) Omega-ydroxyceramides are required for corneocyte lipid envelope (CLE) formation and normal epidermal permeability barrier function. J Invest Dermatol 114: 185-192.

209. Liu Y, Glatt H (2010) Human cytochrome P450 2E1 and sulfotransferase $1 \mathrm{~A} 1$ coexpressed in Chinese hamster V79 cells enhance spontaneous mutagenesis. Environ Mol Mutagen 51: 23-30.

210. Lee SH, Lee SM (2005) Suppression of hepatic cytochrome p450-mediated drug metabolism during the late stage of sepsis in rats. Shock 23: 144-149.

211. Zhou M, Maitra SR, Wang P (2008) The potential role of transcription facto aryl hydrocarbon receptor in downregulation of hepatic cytochrome P-450 during sepsis. Int J Mol Med 21: 423-428.

212. Jacob A, Zhou M, Wu R, Wang $P$ (2009) The role of hepatic cytochrome P-450 in sepsis. Int J Clin Exp Med 2: 203-211.

213. Crawford JH, Yang S, Zhou M, Simms HH, Wang P (2004) Down-regulation of hepatic CYP1A2 plays an important role in inflammatory responses in sepsis. Crit Care Med 32: 502-508.

214. Morgan ET (2005) A role for one or more P450 enzymes in the response to sepsis. Crit Care Med 33: 268-269.

215. Carcillo J, Korzekwa K, Jones G, Parise R, Gillespie D, et al. (1998) The cytochrome P450 suicide inhibitor, 1-aminobenzotriazole, sensitizes rats to zymosan-induced toxicity. Res Commun Molec Pathol Pharmacol 102: 5768.

216. Mico BA, Federowicz DA, Burak E, Swagzdis JR (1987) In vivo inhibition of phenacetin oxidation by suicide substrate 1-aminobenzotriazole. Drug Metab Disp 15: 274-276.

217. Mugford CA, Tarloff JB (1995) Contribution of oxidation and deacetylation to the bioactivation of acetaminophen in vitro in liver and kidney from male and female Sprague-Dawley rats. Drug Metab Dispos 23: 290-294.

218. Mugford CA, Tarloff JB (1997) The contribution of oxidation and deacetylation to acetaminophen nephrotoxicity in female Sprague-Dawley rats. Toxicol Lett 93: 15-22.

219. Deleve LD, Wang X, Kaplowitz N, Shulman HM, Bart JA, et al. (1997) Sinusoidal endothelial cells as a target for acetaminophen toxicity. Direct action versus requirement for hepatocyte activation in different mouse strains. Biochem Pharmacol 53: 1339-1345.

220. Miyakawa K, Albee R, Letzig LG, Lehner AF, Scott MA, et al. (2015) A cytochrome P450-independent mechanism of acetaminophen-induced injury in cultured mouse hepatocytes. J Pharmacol Exp Therap 354: 230-237.

221. Smith RD, Kehrer JP (1991) Cooxidation of cyclophosphamide as an alternative pathway for its bioactivation and lung toxicity. Cancer Res 51 : 542-548.

222. Huang Z, Waxman DJ (2001) Modulation of cyclophosphamide-based cytochrome P450 gene therapy using liver P450 inhibitors. Cancer Gene Ther 8: 450-458.

223. Chen J, Mannargudi BM, Xu L, Uetrecht J (2008) Demonstration of the metabolic pathway responsible for nevirapine-induced skin rash. Chem Res Toxicol 21: 1862-1870.

224. Sharma AM, Li Y, Novalen M, Hayes MA, Uetrecht J (2012) Bioactivation of nevirapine to a reactive quinone methide: implications for liver injury. Chem Res Toxicol 25: 1708-1719.

225. Nishiya T, Kato M, Suzuki T, Maru C, Kataoka H, et al. (2008) Involvement of cytochrome $\mathrm{P} 450$-mediated metabolism in tienilic acid hepatotoxicity in rats. Toxicol Lett 183: 81-89.

226. Jinno N, Tagashira M, Tsurui K, Yamada S (2014) Contribution of cytochrome P450 and UDT-glucuronosyltransferase to the metabolism of drugs containing carboxylic acid groups: risk assessment of acylglucuronides using human hepatocytes. Xenobiotica 44: 677-686.

227. Yang X, Atkinson K, Di L (2016) Novel cytochrome P450 reaction phenotyping for low-clearance compounds using the hepatocyte relay method. Drug Metab Dispos 44: 460-465.

228. Matsunaga N, Kaneko N Staub AY, Nakanishi T, Nunoya K, et al. (2016) Analysis of the metabolic pathway of bosentan and of the cytotoxicity of bosentan metabolites based on a quantitative modeling of metabolism and transport in sandwich-cultured human hepatocytes. Drug Metab Dispos 44 $16-27$

229. Tong V, Chang TKH, Chen J, Abbott FS (2003) The effect of valproic acid on hepatic and plasma levels of 15-F2t-isoprostane in rats. Free Rad Biol Med 34: 1435-1446.

230. Surendradoss J, Chang TKH, Abbott FS (2012) Assessment of the role of in

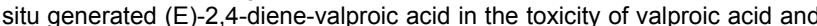
(E)-2-ene-valproic acid in sandwich-cultured rat hepatocytes. Toxicol Appl Pharmacol 264: 413-422.

231. Kazmi F, Barbara JE, Yerino P, Parkinson A (2015) A long-standing mystery solved: the formation of 3-hydroxydesloratadine is catalyzed by CYP2C8 but prior glucuronidation of desloratadine by UDP-glucuronosyltransferase 2B10 is an obligatory requirement. Drug Metab Dispos 43: 523-533.

232. Takagi M, Sanoh S, Santoh M, Ejiri Y, Kotake Y, et al. (2016) Detection of metabolic activation leading to drug-induced phospholipidosis in rat hepatocyte spheroids. J Toxicol Sci 41: 155-164

233. Hammond AH, Fry JR (1994) Toxicity of precocene II in rat hepatocyte cultures: effects of serum and culture time. Toxicol Lett 70: 337-342.

234. Hammond AH, Garle MJ, Fry JR (1995) Mechanism of toxicity of precocene II in rat hepatocyte cultures. J Biochem Toxicol 10: 265-273.

235. Ly VT, Brock B 2011) Effects of CYP inhibitors on precocene I metabolism and toxicity in rat liver slices. Chem Biol Interact 193: 109-118.

236. Huijzer JC, Adams JD, Jaw JY, Yost GS (1989) Inhibition of 3-methylindole bioactivation by the cytochrome P450 suicide substrates 1-aminobenzotriazole and-methylbenzylaminobenzotriazole. Drug Metab Disp 17: 37-42.

237. Nichols WK, Larson DN, Yost GS (1990) Bioactivation of 3-methylindole by isolated rabbit lung cells. Toxicol Appl Pharmacol 105: 264-270.

238. Thornton-Manning JR, Nichols WK, Manning BW, Skiles GL, Yost GS (1993) Metabolism and bioactivation of 3-methylindole by Clara cells, alveolar 
Citation: Ortiz de Montellano PR (2018) 1-Aminobenzotriazole: A Mechanism-Based Cytochrome P450 Inhibitor and Probe of Cytochrome P450 Biology. Med Chem (Los Angeles) 8: 038-065. doi: 10.4172/2161-0444.1000495

macrophages, and subcellular fractions from rabbit lungs. Toxicol Appl Pharmacol 122: 182-190.

239. Nichols WK, Mehta R, Skordos K, Macé K, Pfeifer AM, et al. (2003) 3-Methylindole-induced toxicity to human bronchial epithelial cell lines. Toxicol Sci 71: 229-236.

240. Weems JM, Yost GS (2010) 3-Methylindole metabolites induce lung CYP1A1 and CYP2F1 enzymes by AhR and non-AhR mechanisms, respectively. Chem Res Toxico 23: 696-704.

241. El Hadri L, Bhanas B, Ghanayem BI (2005) Comparative metabolism of methacrylonitrile and acrylonitrile to cyanide using cytochrome P4502E1 and microsomal epoxide hydrolase-null mice. Toxicol Appl Pharmacol 205: 116125

242. Adler ID, Baumgartner A, Gonda H, Friedman MA, Skerhut M (2000) 1-Aminobenzotriazole inhibits acrylamide-induced dominant lethal effects in spermatids of male mice. Mutagenesis 15: 133-136.

243. Park J, Kamendulis LM, Friedman MA, Klaunig JE (2002) Acrylamideinduced cellular transformation. Toxicol Sci 65: 177-183.

244. Lafferty JS, Kamendulis LM, Kaster J, Jiang J, Klaunig JE (2004) Subchronic acrylamide treatment induces a tissue-specific increase in DNA synthesis in the rat. Toxicol Lett 154: 95-103.

245. Zhang H, Kamendulis LM, Klaunig JE (2002) Mechanisms for the induction of oxidative stress in Syrian hamster embryo cells by acrylonitrile. Toxicol Sci 67: 247-255

246. Pu X, Kamendulis LM, Klaunig JE (2006) Acrylonitrile-induced oxidative DNA damage in rat astrocytes. Environ Mol Mutagen 47: 631-638.

247. Saldaña-Ruíz S, Hernández-Mir G, Sedó-Cabezón L, Cutillas B, Llorens J (2012) Vestibular toxicity of cis-2-pentenenitrile in the rat. Toxicol Lett 211: 281-288.

248. Boadas-Vaello P, Jover E, Saldaña-Ruíz S, Soler-Martin C, Chabbert C, et al. (2009) Allylnitrile metabolism by CYP2E1 and other CYPs leads to distinct lethal and vestibulotoxic effects in the mouse. Toxicol Sci 107: 461-472.

249. Constan AA, Sprankle CS, Peters JM, Kedderis GL, Everitt JI, et al. (1999) Metabolism of chloroform by cytochrome P450 2E1 is required for induction of toxicity in the liver, kidney, and nose of male mice. Toxicol Appl Pharmacol 160: $120-126$.

250. Lind RC, Begay CK, Gandolfi AJ (2000) Hepatoprotection by dimethyl sulfoxide. III. Role of inhibition of the bioactivation and covalent bonding of chloroform. Toxicol Appl Pharmacol 166: 145-150.

251. Garner CE, Sumner SCJ, Davis JG, Burgess JP, Yueh Y, et al. (2006) Metabolism and disposition of 1-bromopropane in rats and mice following inhalation or intravenous administration. Toxicol Appl Pharmacol 215: 23-36.

252. Zong C, Garner CE, Huang C, Zhang X, Zhang L, et al. (2016) Preliminary characterization of a murine model for 1-bromopropane neurotoxicity: Role of cytochrome P450. Toxicol Lett 258: 249-258.

253. Nichols WK, Covington MO, Seiders CD, Safiullah S, Yost GS (1992) Bioactivation of halogenated hydrocarbons by rabbit pulmonary cells. Pharmacol Toxicol 71: 335-339.

254. Kim D, Ghanayem BI (2006) Comparative metabolism and disposition of trichloroethylene in Cyp2e1-/ - and wild-type mice. Drug Metab Dispos 34: 2020-2027.

255. Shiba D, Shimamoto N (1999) Attenuation of endogenous oxidative stressinduced cell death by cytochrome P450 inhibitors in primary cultures of rat hepatocytes. Free Rad Biol Med 27: 1019-1026.

256. Bradford BU, Kono H, Isayama F, Kosyk O, Wheeler MD, et al. (2005) Cytochrome P450 2E1, but not nicotinamide adenine dinucleotide phosphate oxidase, is required for ethanol-induced oxidative DNA damage in rodent liver. Hepatology 41: 336-344.

257. Nan Y, Wu W, Fu N, Liang B, Wang R, et al. (2009) Antioxidants vitamin E and 1-aminobenzotriazole prevent experimental non-alcoholic steatohepatitis in mice. Scand J Gastroenterol 44: 1121-1131.

258. Chiu PY, Mak DHF, Poon MKT, Ko KM (2005) Role of cytochrome P-450 in schisandrin B-induced antioxidant and heat shock responses in mouse liver. Life Sci 77: 2887-2895

259. Chen N, Chiu PY, Leung HY, Ko KM (2012) Cytochrome P-450-catalyzed reactive oxygen species production mediates the (-)schisandrin B-induced glutathione and heat shock responses in $\mathrm{H} 9 \mathrm{c} 2$ cardiomyocytes. Indian J Pharmacol 44: 204-209.

260. Dostalek M, Brooks JD, Hardy KD, Milne GL, Moore MM, et al. (2007) In vivo oxidative damage is associated with barbiturate response but not other cytochrome P450 inducers. Molec Pharmacol 72: 1419-1424.

261. Sun X, Ai M, Wang Y, Shen S, Gu Y, et al. (2013) Selective induction of tumor cell apoptosis by a novel P450-mediated reactive oxygen species (ROS) inducer methyl 3-(4-nitrophenyl)propiolate. J Biol Chem 288: 8826-8837.

262. Kadiiska MB, De Costa KS, Mason RP, Mathews JM (2000) Reduction of 1,3-diphenyl-1-triazene by rat hepatic microsomes, by cecal microflora, and in rats generates the phenyl radical metabolite: an ESR spin trapping investigation. Chem Res Toxicol 13: 1082-1086.

263. Ress NB (2002) NTP technical report on the metabolism, toxicity and predicted carcinogenicity of diazoaminobenzene. Toxic Rep Ser 73: 1-23.

264. Dikalova AE, Kadiiska MB, Mason RP (2001) An in vivo ESR spin-trapping study: Free radical generation in rats from formate intoxication - role of the Fenton reaction. Proc Natl Acad Sci USA 98: 13549-13553.

265. Whelan HT, Bajic DM, Karlovits SM, Houle JM, Kindwall EP (1998) Use of cytochrome-P450 monooxygenase 2E1 isozyme inhibitors for delay seizures caused by central nervous system oxygen toxicity. Aviat Space Environ Med 69: $480-485$

266. Muta K, Fukami T, Nakajima M (2015) A proposed mechanism for the adverse effects of acebutolol: CES2 and CYP2C19-mediated metabolism and antinuclear antibody production. Biochem Pharmacol 98: 659-670.

267. Shimizu S, Atsumi R, Itokawa K, Iwasaki M, Aoki T, et al. (2009) Metabolismdependent hepatotoxicity of amodiaquine in glutathione-depleted mice. Arch Toxicol 83: 701-707.

268. Lillibridge JH, Amore BM, Slattery JT, Kalhorn TF, Nelson SD, et al. (1996) Protein-reactive metabolites of carbamazepine in mouse liver microsomes. Drug Metab Dispos 24: 509-514.

269. Wu Y, Sanderson JP, Farrell J, Drummond NS, Hanson A, et al. (2006) Activation of $T$ cells by carbamazepine and carbamazepine metabolites. $J$ Allergy Clin Immunol 118: 233-241.

270. Zhai Y, Wang L, Yang F, Feng G, Feng S, et al. (2016) The mechanism and risk factors of clopidogrel-induced liver injury. Drug Chem Toxicol 39: 367-374.

271. Bumpus NN (2011) Efavirenz and 8-hydroxyefavirenz induce cell death via a JNK- and BimEL-dependent mechanism in primary human hepatocytes. Toxicol Appl Pharmacol 257: 227-234.

272. Shi Q, Yang X, Greenhaw J, Salminen WF (2011) Hepatic cytochrome P450s attenuate the cytotoxicity induced by leflunomide and its active metabolite A77 1726 in primary cultured rat hepatocytes. Toxicol Sci 122: 579-586.

273. Seah QM, New LS, Chan ECY, Boelsterli UA (2008) Oxidative bioactivation and toxicity of leflunomide in immortalized human hepatocytes and kinetics of the non-enzymatic conversion to its major metabolite, A77-1726. Drug Metab Lett 2: 153-157.

274. Graham EE, Walsh RJ, Hirst CM, Maggs JL, Martin S, et al. (2008) Identification of the thiophene ring of methapyrilene as a novel bioactivationdependent hepatic toxicophore. J Pharmacol Exp Therap 326: 657-671.

275. Priestley CC, Regan S, Park BK, Williams DP (2011) The genotoxic potential of methapyrilene using the alkaline Comet assay in vitro and in vivo. Toxicology 290: 249-257.

276. Shimizu S, Atsumi R, Nakazawa T, Izumi T, Sudo K, et al. (2011) Ticlopidineinduced hepatotoxicity in a GSH-depleted rat model. Arch Toxicol 85: $347-$ 353

277. Li AP, Uzgare A, Yumiko S, Laforge YS (2012) Definition of metabolism dependent xenobiotic toxicity with co-cultures of human hepatocytes and mouse 3T3 fibroblasts in the novel integrated discrete multiple organ coculture (IdMOC) experimental system: results with model toxicants aflatoxin B1. Chem Biol Interact 199: 1-8.

278. Li AF, Shen GL, Jiao SY, Li H, Wang Q (2012) Metabolic detoxification of bakuchiol is mediated by cytochrome P450 enzymes in human liver microsomes. Beijing Da Xue Xue Bao 44: 431-436.

279. Reilly CA, Ehlhardt WJ, Jackson IA, Kulanthaivel $P$, Mutlib AE, et al. (2003) Metabolism of capsaicin by cytochrome P450 produces novel 
dehydrogenated metabolites and decreases cytotoxicity to lung and liver cells. Chem Res Toxicol 16: 336-349.

280. Yeh SL, Wu SH (2006) Effects of quercetin on beta-apo-8'-carotenal-induced DNA damage and cytochrome P1A2 expression in A549 cells. Chem Bio Interact 163: 199-206.

281. Beier RC, Norman JO, Irvin TR, Witzel DA (1987) Microsomal activation of constituents of white snakeroot (Eupatorium rugosum Houtt) to form toxic products. Am J Vet Res 48: 583-585.

282. Marczylo T, loannides C (1999) Evidence for the presence of a microsomal $\mathrm{NADH}$-dependent enzyme system that can bioactivate aromatic amines in the liver of rats and mice. Toxicology 134: 127-141.

283. Jiang H, Lai Y, Hu K, Wei Q, Liu Y (2014) Human CYP2E1-dependent and human sulfotransferase 1A1-modulated induction of micronuclei by benzene and its hydroxylated metabolites in Chinese hamster V79-derived cells. Mutat Res 770: 37-44.

284. Bolton JL, Thompson JA (1991) Oxidation of butylated hydroxytoluene to toxic metabolites. Factors influencing hydroxylation and quinone methide formation by hepatic and pulmonary microsomes. Drug Metab Dispos 19: 467-472.

285. van Ravenzwaay B, Gamer AO, Leibold E, Kaufmann W (2003) Effect of cytochrome P450 inhibition of tetrahydrofuran-induced hepatocellular proliferation in female mice. Arch Toxicol 77: 459-464.

286. Mann KK, Matulka RA, Hahn ME, Trombino AF, Lawrence BP, et al. (1999) The role of polycyclic aromatic hydrocarbon metabolism in dimethylbenz[a] anthracene-induced pre-B lymphocyte apoptosis. Toxicol Appl Pharmaco 161: 10-22.

287. Zhang C, Lai Y, Jin G, Glatt H, Wei Q, et al. (2016) Human CYP2E1dependent mutagenicity of mono- and dichlorobiphenyls in Chinese hamster (V79(-derived cells. Chemosphere 144: 1908-1915.

288. Nyarko AK, Kellner-Weibel GL, Harvison PJ (1997) Cytochrome P450mediated metabolism and nephrotoxicity of $\mathrm{N}$-(3,5-dichlorophenyl) succinimide in Fischer 344 rats. Fundam Appl Toxicol 37: 117-124.

289. Henesey CM, Harvison PJ (2002) Renal damage, metabolism and covalent binding following administration of the nephrotoxicant $\mathrm{N}$-(3,5-dichlorophenyl) succinimide to male Fischer 344 rats. Toxicology 170: 187-200.

290. Crincoli CM, Patel NN, Tchao R, Harvison PJ (2008) Role of biotransformation in 3-(3,5-dichlorophenyl)-2,4-thiazolidinedione-induced hepatotoxicity. Toxicology 250: 100-108.

291. Deng H, Gao H, Liu Y (2011) Biotransformation enzyme-dependent formation of micronucleus and multinuclei in cell line V79-hCYP2E1-hSULT1A1 by 2-nitropropane and N-nitrosodimethylamine. Mutat Res 726: 84-87.

292. Yeh SL, Wang WY, Huang CS, Hu ML (2006) Flavonoids suppress the enhancing effect of beta-carotene on DNA damage induced by 4-(methylnitrosamino)-1-(3-pyridyl)-1-butanone (NNK) in A549 cells. Chem Biol Interact 160: 175-182.

293. King LC, Kohan MJ, Brooks L, Nelson GB, Ross JA, et al. (2001) An evaluation of the mutagenicity, metabolism, and DNA adduct formation of 5-nitrobenzo[b]naptho[2,1-d]thiophenes. Chem Res Toxicol 14: 661-671.

294. Zhang D, Flint O, Wang L, Gupta A, Westhouse RA, et al. (2012) Cytochrome P450 11A1 bioactivation of a kinase inhibitor in rats: use of radioprofiling modulation of metabolism, and adrenocortical cell lines to evaluate adrenal toxicity. Chem Res Toxicol 25: 556-571.

295. Jackson JA, Birnbaum LS, Diliberto JJ (1998) Effects of age, sex, and pharmacologic agents on the biliary elimination of 2,3,7,8-tetrachlorodibenzop-dioxin (TCDD) in F344 rats. Drug Metab Dispos 26: 714-719.

296. Vyas PM, Roychowdhury S, Khan FD, Prinsinzano TE, Lamba J, et al. (2006) Enzyme-mediated protein haptenation of dapsone and sulfamethoxazole in human keratinocytes: I. Expression and role of cytochrome P450s. J Pharm Exp Therap 319: 488-496.

297. Aloysius H, Tong VW, Yabut J, Bradley SA, Shang J, et al. (2012) Metabolic activation and major protein target of a 1-benzyl-carboxyazetidine sphigosine1-phosphate-1 receptor agonist. Chem Res Toxicol 25: 1412-1422.

298. Zhou L, Pang X, Xie C, Zhong D, Chen X (2015) Chemical and enzymatic transformations of nimesulide to GSH conjugates through reductive and oxidative mechanisms. Chem Res Toxicol 28: 2267-2277.
299. Shao R, Ring SC, Tarloff JB (1997) Coincubation of rat renal proxima tubules with hepatic subcellular fractions potentiates the effects of paraaminophenol. Fundam. Appl Toxicol 39: 101-108.

300. Dierickx PJ (1999) CYP1/2 activation and glutathione-dependent cytotoxicity of four pesticides in Hep G2 and Fa32 cells. Toxicol in Vitro 13: 779-783.

301. Salaün JP, Simon A, Durst F, Reich NO, Ortiz de Montellano PR (1988) Differential inactivation of plant lauric acid omega- and in-chain hydroxylases by terminally unsaturated fatty acids. Arch Biochem Biophys 260: 540-545.

302. Pflugmacher S, Sandermann H Jr (1998) Cytochrome P450 monooxygenases for fatty acids and xenobiotics in marine macroalgae. Plant Physiol 117: 123128.

303. Menting JGT, Scopes RK, Stevenson TW (1994) Characterization of flavonoid 3',5'-hydroxylase in microsomal membrane fraction of petunia hybrida flowers. Plant Physiol 106: 633-642.

304. Aghofack-Nguemezi J, Fuchs C, Yeh SY, Huang FC, Hoffmann T, et al (2011) An oxygenase inhibitor study in Solanum lycopersicum combined with metabolite profiling analysis revealed a potent peroxygenase inactivator. $J$ Exp Bot 62: 1313-1323.

305. Morgan JA, Shanks JV (1999) Inhibitor studies of tabersonine metabolism in C. roseus hairy roots. Phytochemistry 51: 61-68.

306. Werck-Reichhart D, Gabriac B, Teutsch H, Durst F (1990) Two cytochrome P450 isoforms catalyzing O-de-ethylation of ethoxycoumarin and ethoxyresorufin in higher plants. Biochem J 270: 729-735.

307. Cabanne F, Huby D, Gaillardon P, Scalla R, Durst F (1987) Effect of the cytochrome P450 inactivator 1-aminobenzotriazole on the metabolism of chlortoluron and isoproturon in wheat. Pest Biochem Physiol 28: 371-380.

308. McFadden JJ, Frear DS, Mansager ER (1989) Aryl hydroxylation of diclofop by a cytochrome P450 dependent monooxygenase from wheat. Pest Biochem Physiol 34: 92-100.

309. Sterling TM, Balke NE (1990) Bentazon uptake and metabolism by cultured plant cells in the presence of monooxygenase inhibitors and cinnamic acid. Pest Biochem Physiol 38: 66-75.

310. Gronwald JW, Connelly JA (1991) Effect of monooxygenase inhibitors on bentazon uptake and metabolism in maize cell suspension cultures. Pest Biochem Physiol 40: 284-294.

311. Letouzé A, Gasquez J (2003) Enhanced activity of several herbicidedegrading enzymes; a suggested mechanism responsible for multiple resistance in blackgrass (Aloecurus myosuroides Huds.). Agronomie 23: 601-608.

312. Moreland DE, Corbin FT, McFarland JE (1993) Effects of safeners on the oxidation of multiple substrates by grain sorghum microsomes. Pest Biochem Physiol 45: 43-53.

313. Aper J, Mechant E, Rubin B, Heyerick A, Callebaut G, et al. (2012) Absorption, translocation and metabolism of metamitron in Chenopodium album. Pest Manag Sci 68: 209-216.

314. Elmore MT, Brosnan JT, Armel GR, Kopsell DA, Best MD, et al. (2015) Cytochrome P450 inhibitors reduce creeping bentgrass (Agrostis stolonifera) tolerance to topramezone. Plos One 10: e0130947.

315. Zhai G, Lehmler HJ, Schnoor JL (2013) Inhibition of cytochromes P450 and the hydroxylation of 4-monochlorobiphenyl in whole poplar. Environ Sci Technol 47: 29-35.

316. Miranda CL, Henderson MC, Buhler DR (1998) Evaluation of chemicals as inhibitors of trout cytochrome P450s. Toxicol App Pharmacol 148: 237-244.

317. Hamm JT, Wilson BW, Hinton DE (2001) Increasing uptake and bioactivation with development positively modulate diazinon toxicity in early life stage medaka (Oryzias latipes). Toxicol Sci 61: 304-313.

318. Cashman, JR, Olsen LD, Young G, Bern H (1989) S-oxygenation of eptam in hepatic microsomes from fresh- and salt-water striped bass (Morone saxatilis). Chem Res Toxicol 2: 392-399.

319. Wang SP, Hu XX, Meng QM, Muhammad SA, Chen RR, et al. (2013) The involvement of several enzymes in methanol detoxification in Drosophila melanogaster adults. Comp Biochem Physiol B Biochem Mol Biol 166: 7-14.

320. Mathies A, Walker F, Buchenauer H (1999) Interference of selected fungicides, plant growth retardants as well as piperonyl butoxide and 1 -aminobenzotriazole in trichothecene production of Fusarium graminearum 
Citation: Ortiz de Montellano PR (2018) 1-Aminobenzotriazole: A Mechanism-Based Cytochrome P450 Inhibitor and Probe of Cytochrome P450 Biology. Med Chem (Los Angeles) 8: 038-065. doi: 10.4172/2161-0444.1000495

(strain 4528) in vitro. J Plant Dis Protect 106: 198-212.

321. Ishikawa NK, Tahara S, Namatame T, Farooq A, Fukushi Y (2013) Use of cytochrome P450 inhibitors in studies of enokipodin biosynthesis. Brazil J Microbiol 44: 1285-1290.

322. Thompson ML, Marriott R, Dowle A, Grogan G (2010) Biotransformation of beta-myrcene to geraniol by a strain of Rhodococcus erythropolis isolated by selective enrichment from hop plants. Appl Microbiol Biotechnol 85: 721-730.

323. Mori T, Kondo R (2002) Oxidation of dibenzo-p-dioxin, dibenzofuran, biphenyl, and diphenyl ether by the white-rot fungus Phlebia lindtneri. Appl Microbiol Biotechnol 60: 200-205

324. Mori T, Kitano S, Kondo R (2003) Biodegradation of chloronaphthalenes and polycyclic aromatic hydrocarbons by the white-rot fungus Phlebia lindtneri. Appl Microbiol Biotechnol 61: 380-383.

325. Hata T, Kawai S, Okamura H, Nishida T (2010) Removal of diclofenac and mefenamic acid by the white rot fungus Phanerochaete sordida YK-624 and identification of their metabolites after fungal transformation. Biodegradation 21: 681-689.

326. Marco-Urrea E, Pérez-Trujillo M, Cruz-Morató C, Caminal G, Vicent T (2010) White-rot fungus-mediated degradation of the analgesic ketoprofen and identification of intermediates by HPLC-DAD-MS and NMR. Chemosphere 78: 478-481.

327. Prieto A, Möder M, Rodil R, Adrian L, Marco-Urrea E (2011) Degradation of the antibiotics norfloxacin and ciprofloxacin by a white-rot fungus and identification of degradation products. Bioresour.Technol 102: 10987-10995.

328. da Silva Celho-Moreira J, Bracht A, da Silva de Souza AC, Oliveira RF, Babeto de Sá-Nakanishi A, et al. (2013) Degradation of diuron by Phanerochaete chrysosporium: role of ligninolytic enzymes and cytochrome P450. BioMed Res Internat 2013: 1-9.

329. Van Damme JD, Wong ET, Dettman H, Gray MR, Pickard MA (2003) Dibenzy sulfide metabolism by white rot fungi. Appl Environ Microbiol 69: 1320-1324.

330. Kanaly RA, Hur HG (2006) Growth of Phanerochaete chrysosporium on diesel fuel hydrocarbons at neutral $\mathrm{pH}$. Chemosphere 63: 202-211.

331. Marco-Urrea E, Parella T, Gabarrell X, Caminal G, Vicent T, et al. (2008) Mechanistics of trichloroethylene mineralization by the white-rot fungus Trametes versicolor. Chemosphere 70: 404-410.

332. Marco-Urrea E Pérez-Trujillo M, Caminal G, Vicent T (2009) Dechlorination of 1,2,3- and 1,2,4-trichlorobenzene by the white-rot fungus Trametes versicolor. J Hazard Mater 166: 1141-1147.

333. Marco-Urrea E, Pérez-Trujillo M, Vicent T, Caminal G (2009) Ability of whiterot fungi to remove selected pharmaceuticals and identification of degradation products of ibuprofen by Trametes versicolor. Chemosphere 74: 765-772.

334. Marco-Urrea E, Pérez-Trujillo M, Blánquez P, Vicent T, Caminal G (2010) Biodegradation of the analgesic naproxen by Trametes versicolor and identification of intermediates using HPLC-DAD-MS and NMR. Bioresour Technol 101: 2159-2166.

335. Marco-Urrea E, Pérez-Trujillo M, Criuz-Morató C, Caminal G, Vicent T (2010) Degradation of the drug sodium diclofenac by Trametes versicolor pellets and identification of some intermediates by NMR. J Hazard Mater 176: 836842.

336. Bezalel L, Hadar Y, Cerniglia CE (1997) Enzymatic mechanisms involved in phenanthrene degradation by the white rot fungus Pleurotus ostreatus. App Environ Microbiol 63: 2495-2501.

337. Lisowska K, Diugonski J (2003) Concurrent corticosteroid and phenanthrene transformation by filamentous fungus Cunninghamella elegans. J Steroid Biochem Mol Biol 85: 63-69.

338. Schlenk D, Bevers RJ, Vertino AM, Cerniglia CE (1994) P450 catalyzed S-oxidation of dibenzothiophene by Cunninghamella elegans. Xenobiotica 24: 1077-1083.

339. Zhang D, Evans FE, Freeman JP, Duhart B, Cerniglia CE (1995) Biotransformation of amitriptyline by Cunninghamella elegans. Drug Metab Disp 23: 1417-1425

340. Holland HL, Morris TA, Nava PJ, Zabic M (1999) A new paradigm for biohydroxylation by Beauveria bassiana ATCC 7159. Tetrahedron 55: 7441 7460 .

341. Mitsukura K, Kondo Y, Yoshida T, Nagasawa T (2006) Regioselective hydroxylation of adamantane by Streptomyces griseoplanus cells. Appl Microbiol Biotechnol 71: 502-504.

342. Rappert S, Li R, Kokova M, Antholz M, Nagorny S, et al. (2007) Degradation of 2,5-dimethylpyrazine by Rhodococcus erythropolis strain DP-45 isolated from a waste gas treatment plant of a fishmeal processing company. Biodegradation 18: 585-596.

343. Hong CY, Kim HY, Lee SY, Kim SH, Lee SM, et al. (2013) Involvement of extracellular and intracellular enzymes of Ceriporia sp. ZLY-2010 for biodegradation of polychlorinated biphenyls (PCBs). J Environ Sci Health A Tox Hazard Subst Environ Eng 48: 1280-1291. 